\title{
Bench-scale Kinetics Study of Mercury Reactions in FGD Liquors
}

\author{
Final Report
}

Project Period of Performance:

September 30, 2004 - March 31, 2008

Prepared by:

Gary M. Blythe

John Currie

David W. DeBerry, PhD

August 2008

Cooperative Agreement No: DE-FC26-04NT42314

URS Group

9400 Amberglen Boulevard

Austin, Texas 78729

\author{
Prepared for: \\ Charles Miller \\ National Energy Technology Laboratory \\ U.S. Department of Energy \\ 626 Cochrans Mill Road \\ Pittsburgh, PA 15236
}





\section{DISCLAIMER}

This report was prepared as an account of work sponsored by an agency of the United States Government. Neither the United States Government nor any agency thereof, nor any of their employees, makes any warranty, express or implied, or assumes any legal liability or responsibility for the accuracy, completeness, or usefulness of any information, apparatus, product, or process disclosed, or represents that its use would not infringe privately owned rights. Reference herein to any specific commercial product, process, or service by trade name, trademark, manufacturer, or otherwise does not necessarily constitute or imply its endorsement, recommendation, or favoring by the United States Government or any agency thereof. The views and opinions of authors expressed herein do not necessarily state or reflect those of the United States Government or any agency thereof. 


\section{ABSTRACT}

This document is the final report for Cooperative Agreement DE-FC26-04NT42314, "Kinetics Study of Mercury Reactions in FGD Liquors." The project was co-funded by the U.S. DOE National Energy Technology Laboratory and EPRI. The objective of the project has been to determine the mechanisms and kinetics of the aqueous reactions of mercury absorbed by wet flue gas desulfurization (FGD) systems, and develop a kinetics model to predict mercury reactions in wet FGD systems. The model may be used to determine optimum wet FGD design and operating conditions to maximize mercury capture in wet FGD systems.

Initially, a series of bench-top, liquid-phase reactor tests were conducted and mercury species concentrations were measured by UV/visible light spectroscopy to determine reactant and byproduct concentrations over time. Other measurement methods, such as atomic absorption, were used to measure concentrations of vapor-phase elemental mercury, that cannot be measured by UV/visible light spectroscopy.

Next, a series of bench-scale wet FGD simulation tests were conducted. Because of the significant effects of sulfite concentration on mercury re-emission rates, new methods were developed for operating and controlling the bench-scale FGD experiments. Approximately 140 bench-scale wet FGD tests were conducted and several unusual and pertinent effects of process chemistry on mercury re-emissions were identified and characterized.

These data have been used to develop an empirically adjusted, theoretically based kinetics model to predict mercury species reactions in wet FGD systems. The model has been verified in tests conducted with the bench-scale wet FGD system, where both gas-phase and liquid-phase mercury concentrations were measured to determine if the model accurately predicts the tendency for mercury re-emissions.

This report presents and discusses results from the initial laboratory kinetics measurements, the bench-scale wet FGD tests, and the kinetics modeling efforts. 


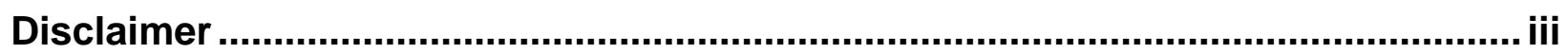

Abstract................................................................................................................... iv

Executive Summary .......................................................................................... ix

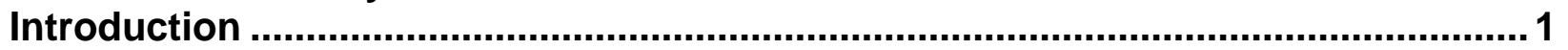

Experimental.......................................................................................................... 2

Task 2: Kinetic Data Gathering and Initial Model Development............................ 2

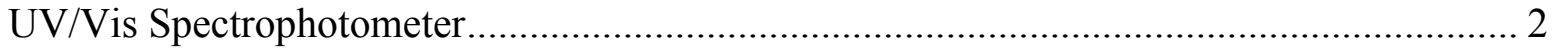

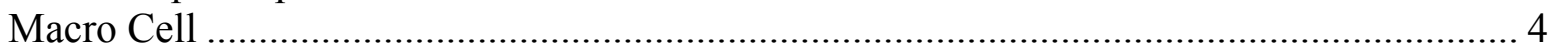

AA Spectrophotometer ................................................................................... 4

Task 3: Model Refinement, Bench-scale Validation and Additive Testing ................ 5

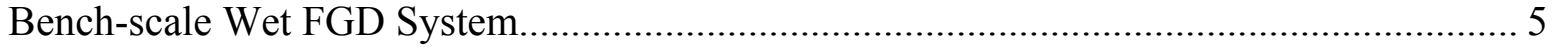

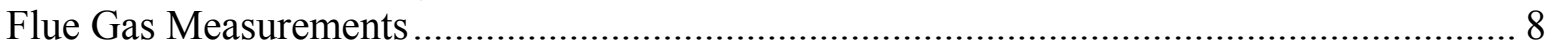

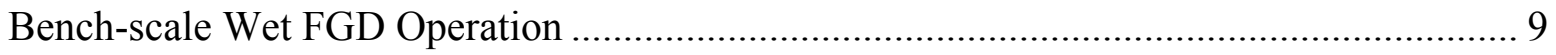

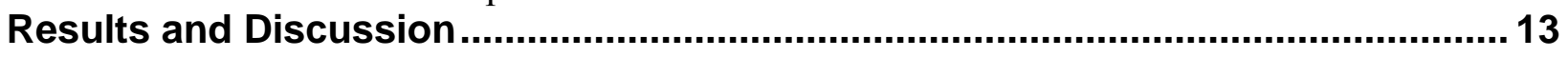

Task 2: Kinetic Data Gathering and Initial Model Development ........................ 13

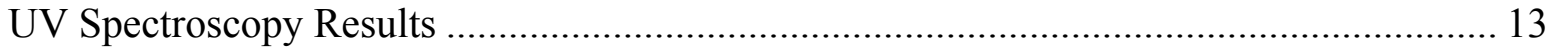

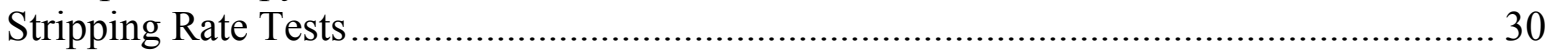

Task 3: Model Refinement, Bench-scale Validation and Additive Testing .............. 40

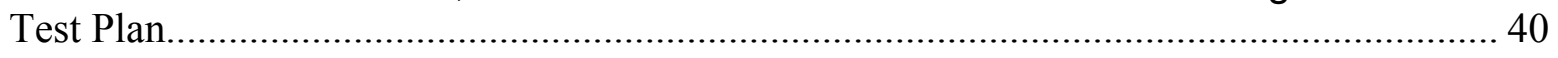

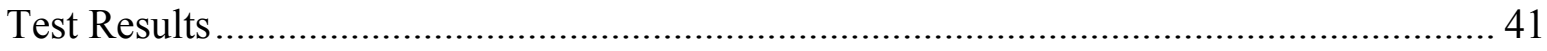

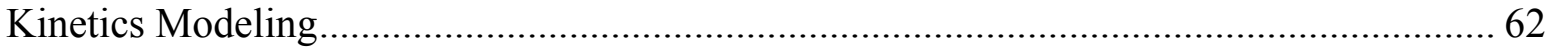

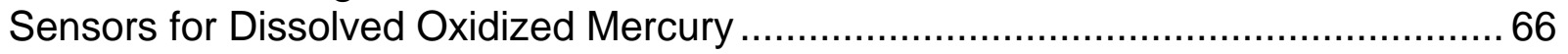

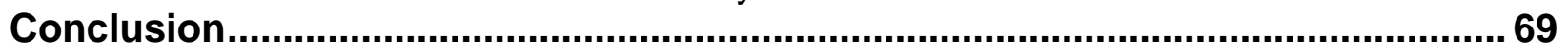

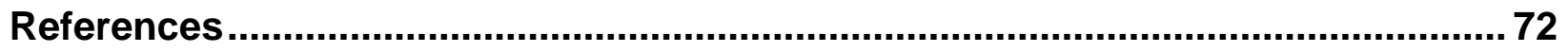




\section{LIST OF FIGURES}

Figure 1. Photo of UV/Vis Spectrometer and Cell Holder Apparatus 3

Figure 2. Multi-port Reaction Cell in Thermostatted Bath Showing Pumping to External

Thermostatted Spectrophotometric Cell ......................................................... 5

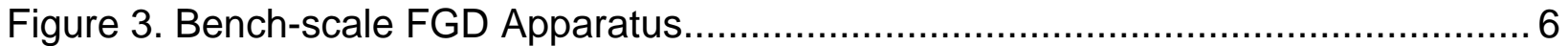

Figure 4. Bench-scale Simulation Gas Mixing Apparatus..................................... 7

Figure 5. Schematic of Mercury SCEM ................................................................ 8

Figure 6. Time Profiles for a Typical Run Including Preliminary Setup and Calibration. 11

Figure 7. Example of Period for Which Re-emissions are Measured ........................... 12

Figure 8. Experimental Absorbance and Spectra Data for Mercury Disulfite................... 14

Figure 9. Effect of $\mathrm{pH}$ on Rate Curves (no chloride; $55^{\circ} \mathrm{C} ; 1.0 \mathrm{mM}$ sulfite; $40 \mu \mathrm{M} \mathrm{Hg}^{+2}$ )

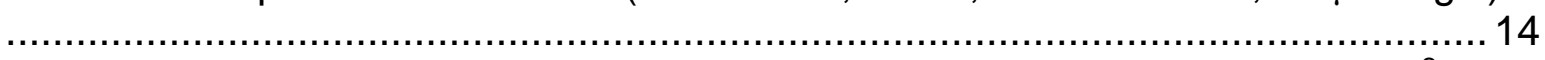

Figure 10. Effect of Sulfite on Rate Curves (no chloride; $55^{\circ} \mathrm{C}$; $\mathrm{pH} 3.9 ; 40 \mu \mathrm{M} \mathrm{Hg}{ }^{+2}$ )... 15

Figure 11. Effect of Temperature on $\mathrm{k}_{\mathrm{obs}}$ (no chloride, $\mathrm{pH}$ 3.0, $1.0 \mathrm{mM}$ sulfite, $40 \mu \mathrm{M}$

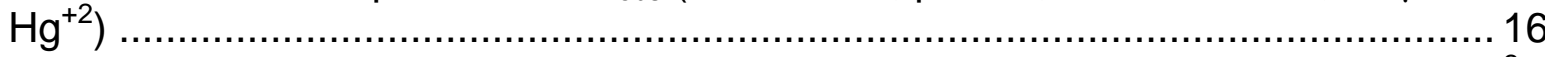

Figure 12. Effect of Chloride on Rate Curve ( $\mathrm{pH} 3.0,55^{\circ} \mathrm{C}, 1.0 \mathrm{mM}$ sulfite, $40 \mu \mathrm{M} \mathrm{Hg}^{+2}$ )

Figure 13. Effect of Adding Chloride After Start of Run (1.0 mM sulfite, $55^{\circ} \mathrm{C}, 40 \mu \mathrm{M}$

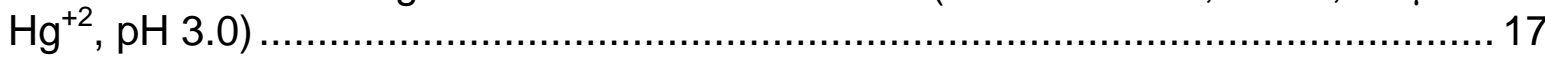

Figure 14. Effect of $10 \mathrm{mM}$ Chloride at Different $\mathrm{pH}$ Values $\left(55^{\circ} \mathrm{C}, 1.0 \mathrm{mM}\right.$ sulfite, 40

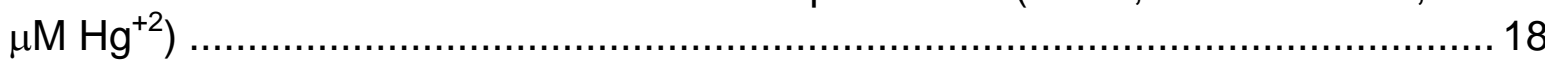

Figure 15. $\mathrm{pH}$ Dependence of $\mathrm{k}_{\mathrm{obs}}$ with and without $0.01 \mathrm{M}$ Chloride $\left(55^{\circ} \mathrm{C}, 1.0 \mathrm{mM}\right.$

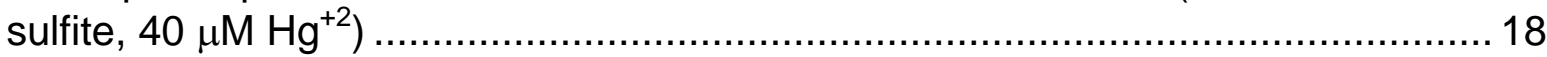

Figure 16. Shift in UV Spectra on Adding $10 \mathrm{mM}$ Chloride to pH 3.0, $1.0 \mathrm{mM}$ Sulfite, 40 $\mu \mathrm{M} \mathrm{Hg}{ }^{+2}$ Solution at $55^{\circ} \mathrm{C}$

Figure 17. Absorbance at $232 \mathrm{~nm}$ During Addition of Sulfite to a Solution Containing 1.0

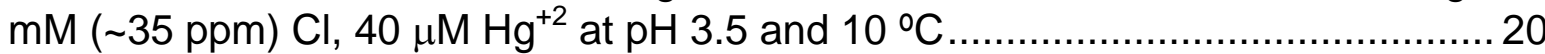

Figure 18. Rate Curves for Addition of $1.0 \mathrm{mM}$ Sulfite to Solutions Containing $10 \mathrm{mM}$, $30 \mathrm{mM}$, and $100 \mathrm{mM}$ Chloride $\left(55^{\circ} \mathrm{C}, \mathrm{pH} 3-3.5,40\right.$ microM Hg$\left.{ }^{+2}\right) \ldots \ldots \ldots \ldots \ldots \ldots \ldots . . .21$

Figure 19. Rate Curves for Addition of $1.0 \mathrm{mM}$ Sulfite to Solutions Containing $10 \mathrm{mM}$, $250 \mathrm{mM}$, and $1000 \mathrm{mM}$ Chloride $\left(55^{\circ} \mathrm{C}, \mathrm{pH} 3-3.5,40\right.$ microM Hg${ }^{+2}$ ) ................. 22

Figure 20. Rate Curves at Two Wavelengths on Addition of $1.0 \mathrm{mM}$ Sulfite to Solution Containing $1000 \mathrm{mM}$ Chloride $\left(55^{\circ} \mathrm{C}, \mathrm{pH} 3.5,40\right.$ microM $\mathrm{Hg}^{+2}$ ).

Figure 21. Effect of Adding a Magnesium Chip to a Solution Containing $1.0 \mathrm{M} \mathrm{NaCl}$ and 40 microM Hg+2 at $55^{\circ} \mathrm{C}$ 24

Figure 22. Ionic Strength Dependence of $\mathrm{k}_{\mathrm{obs}}\left(55^{\circ} \mathrm{C}, 1.0 \mathrm{mM}\right.$ sulfite, $\mathrm{pH} 3.0,40$ microM $\mathrm{Hg}^{+2}$ )

Figure 23. Rate Curve at Two Wavelengths for the Addition of Sulfite to a Solution

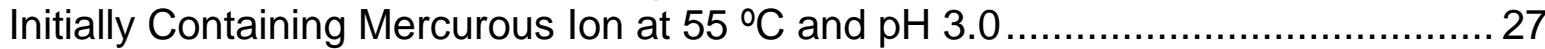

Figure 24. Comparison of Time Profiles for Fresh Chloroacetate Buffer and Buffer Exposed to Mercuric Ion for Several Days.... 28

Figure 25. Absorbance and OCP on Addition of $40 \mu \mathrm{M} \mathrm{Hg}^{+2}$ and $1.0 \mathrm{mM}$ Sulfite to Solution Containing $10 \mathrm{mM}$ Chloride and $20 \mathrm{mM}$ Acetate Buffer $\left(55^{\circ} \mathrm{C}, \mathrm{pH} 4.1\right)$... 29 
Figure 26. Evolution of Gas Phase $\mathrm{Hg}^{0}$ from Reaction at $50{ }^{\circ} \mathrm{C}$ (initially at $\mathrm{pH} 3.0$ and spiked with $0.5 \mu \mathrm{M} \mathrm{Hg}^{2+} ; 184 \mathrm{ppm} \mathrm{SO}{ }_{2}$ in gas; $\mathrm{pH} 2.65$ and $0.93 \mathrm{mM}$ sulfite in liquid after the run)

Figure 27. $\mathrm{Hg}^{0}$ Stripping Kinetics Results for Addition of $1.0,1.5$, and $2.0 \mathrm{mM} \mathrm{Hg}^{+2}$ to Solution Containing $1.3 \mathrm{mM}$ Sulfite at pH 3.1, with 124 ppm SO 2 in Gas Phase at $55^{\circ} \mathrm{C}$

Figure 28. Stripping Kinetics Results with and without $10 \mathrm{mM}$ Chloride at $55^{\circ} \mathrm{C}$.......... 33

Figure 29. Stripping Kinetics Results with $10 \mathrm{mM}, 100 \mathrm{mM}$ and $250 \mathrm{mM}$ Chloride at 55 ${ }^{\circ} \mathrm{C}$

Figure 30. Percentage of Mercury Stripped from Solution, as a Function of Chloride Concentration.

Figure 31. Effect of Adding $1.0 \mathrm{mM}$ Thiosulfate to a $100 \mathrm{mM}$ Chloride Solution on $\mathrm{Hg}^{0}$ Stripping Kinetics

Figure 32. Comparison of Effects of $80 \mu \mathrm{M}$ lodide and $80 \mu \mathrm{M}$ Chloride on Kinetics of

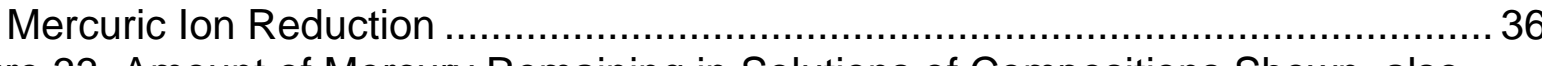

Figure 33. Amount of Mercury Remaining in Solutions of Compositions Shown, also Containing $100 \mathrm{mM} \mathrm{NaCl}$ and $100 \mathrm{mM}$ Acetate Buffer, on Continuous Stripping with $\mathrm{N}_{2}-\mathrm{SO}_{2}$ Gas Mixture (Solution spiked with $4.0 \mu \mathrm{M} \mathrm{Hg}\left(\mathrm{ClO}_{4}\right)_{2}$ at $\mathrm{t}=0$ ) .................. 37

Figure 34. Observed Rate Constants for Reduction and Stripping of Mercury in $1.0 \mathrm{mM}$ Sodium Sulfite Solutions as a Function of $\mathrm{pH}$. (Solutions contained $100 \mathrm{mM} \mathrm{NaCl}$ and $100 \mathrm{mM}$ sodium acetate at $55^{\circ} \mathrm{C}$ ).

Figure 35. Observed Rate Constants for Reduction and Stripping of Mercury in $5.0 \mathrm{mM}$ Sodium Sulfite Solutions as a Function of $\mathrm{pH}$. (Solutions contained $100 \mathrm{mM} \mathrm{NaCl}$ and $100 \mathrm{mM}$ sodium acetate at $55^{\circ} \mathrm{C}$ ).

Figure 36. Observed Rate Constants for Reduction and Stripping of Mercury in $20 \mathrm{mM}$ Sodium Sulfite Solutions as a Function of $\mathrm{pH}$. (Solutions contained $100 \mathrm{mM} \mathrm{NaCl}$ and $100 \mathrm{mM}$ sodium acetate at $55^{\circ} \mathrm{C}$ ).

Figure 37. Observed and Model-Simulated Rate Constants for Reduction and Evolution of Mercury in 1.0, 5.0, and $20 \mathrm{mM}$ Sodium Sulfite Solutions as a Function of pH. (Solutions contained $100 \mathrm{mM} \mathrm{NaCl}$ and $100 \mathrm{mM}$ sodium acetate at $55^{\circ} \mathrm{C}$ )........... 39

Figure 38. Bench-scale Re-emissions as a Function of $\mathrm{pH}$....................................5 51

Figure 39. Effect of pH on Re-emissions at $0.2 \mathrm{mM}$ Sulfite, $100 \mathrm{mM}$ Chloride .............. 52

Figure 40. Bench-scale Re-emissions as a Function of pH, including $0.2 \mathrm{mM}$ Sulfite

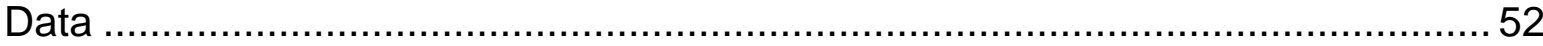

Figure 41. Effects of Chloride and Bromide Concentrations on Bench-scale Mercury Reemissions at pH 5, $5 \mathrm{mM}$ sulfite .................................................................. 53

Figure 42. Bench-scale Re-emissions as a Function of $\mathrm{HgCl}_{2}$ Added........................53

Figure 43. Effect of Calcium on $\mathrm{Hg}^{0}$ Re-emissions at pH 4.0 with Varying Sulfite, 100

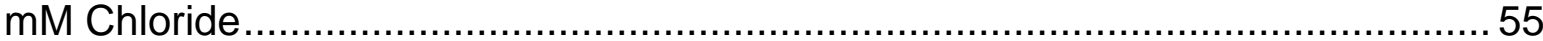

Figure 44. Effect of Calcium on $\mathrm{Hg}^{0}$ Re-emissions at pH 6.0 with Varying Sulfite, 100

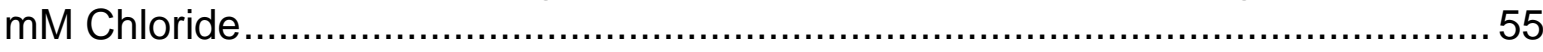

Figure 45. Effect of $\mathrm{N}$-compounds on Bench-scale Re-emissions at $100 \mathrm{mM} \mathrm{Cl}, 55^{\circ} \mathrm{C}$

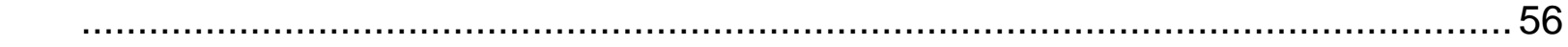

Figure 46. Bench-scale Re-emissions at $1 \mathrm{mM}$ Thiosulfate, as a Function of $\mathrm{pH}$.........55 57 Figure 47. Bench-scale Re-emissions for Carboxylic Acid Salts at $100 \mathrm{mM} \mathrm{Cl}^{-}, 55^{\circ} \mathrm{C} . .58$ 
Figure 48. Bench-scale Re-emissions for Several Re-emissions Inhibitors at $100 \mathrm{mM} \mathrm{Cl}^{-}$

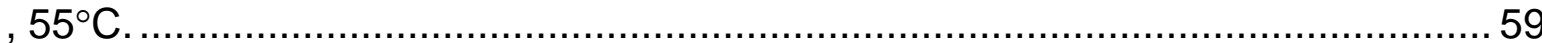

Figure 49. Bench-scale Re-emissions for Additional Re-emissions Inhibitors at pH 5,

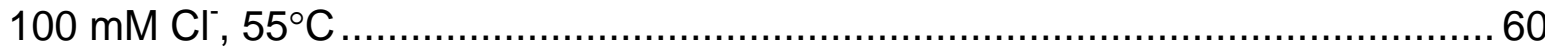

Figure 50. Re-emission Results for $10 \mathrm{mM}$ Iron Salts at pH 4.0, $100 \mathrm{mM}$ Chloride ...... 62

Figure 51. Schematic Diagram of Main Reaction Pathways in Current Kinetics Model. 65

\section{LIST OF TABLES}

Table 1. Results of Bench-scale Mercury Re-emission Tests

Table 2. Reaction Set and Kinetics Parameters for $\mathrm{Hg}-\mathrm{SO}_{2}$ Reaction Model as Determined at Completion of the Task 3 Kinetics Data Gathering Effort (see text for symbol explanation and units)..... 63 


\section{EXECUTIVE SUMMARY}

This document is the final report for DOE-NETL Cooperative Agreement DE-FC2604NT42314, "Bench-scale Kinetics Study of Mercury Reactions in FGD Liquors." In the project, experimental methods were developed initially to use spectrophotometry to identify key reaction intermediate species in the reduction of oxidized mercury to elemental mercury under wet flue gas desulfurization (FGD) conditions, and to track their changes in concentration as the reactions proceeded. Separate but complementary methods for following the rate of evolution of mercury into the gas phase, and loss of mercury from the liquid phase were developed and applied. Using these methods, it has been determined that mercuric sulfite and chlorosulfite complexes form when oxidized mercury is absorbed by FGD systems, and correspondingly decompose to produce elemental mercury re-emissions. The rate of disappearance of the mercuric sulfite and chlorosulfite complexes and the corresponding rate of formation of elemental mercury were monitored by independent means. This enabled the project team to map out and model the major reaction pathways, and the effects of temperature, reactant concentrations, $\mathrm{pH}$, chloride, thiosulfate, and other complexing agents on the rates of these reactions, and thus on the reemission of $\mathrm{Hg}$ from FGD systems.

New methods for operating and controlling an existing bench-scale wet FGD system were developed and a number of bench-scale FGD runs were completed. These runs have confirmed and considerably augmented the initial kinetics results.

The results show that mercury re-emissions increase linearly with total concentration of mercuric ion in the FGD reaction tank liquor. Even low concentrations of chloride have a significant effect on the rate of mercuric ion reduction by sulfite. Evidence has been found for the formation of complexes of mercuric ion with both sulfite and up to two chloride ions. Each chloride ion attached to the mercury slows the decomposition of the mercuric chloride complex to elemental mercury by a substantial amount. The key role played by the sulfite aqueous species $\left(\mathrm{SO}_{3}{ }^{-2}\right)$ indicates that other solution components (such as magnesium and calcium) which ion pair with sulfite could also influence the kinetics of mercury reduction. Calcium effects on re-emission were found to increase with increasing $\mathrm{pH}$.

Effects of $\mathrm{pH}$ and sulfite concentration are complex and appreciable, particularly at low sulfite concentrations. Low concentrations of sulfite (consistent with forced oxidation conditions) produced high re-emissions and an unusual $\mathrm{pH}$ response: increased re-emissions as the $\mathrm{pH}$ increases from 4.0 to 6.0. At higher sulfite concentrations, re-emissions generally decrease with increasing $\mathrm{pH}$. Thiosulfate appears to inhibit re-emission at low $\mathrm{pH}$, but accelerate it at high $\mathrm{pH}$. Effects of N-compounds are also mixed. Sulfur-nitrogen species in the FGD liquor, which form over time as a result of $\mathrm{NO}_{\mathrm{X}}$ in the scrubbed gas, tend to increase re-emissions. $\mathrm{NO}_{\mathrm{X}}$ in the simulated flue gas tends to lower re-emissions when sulfur-nitrogen species are not present in the FGD liquor. Thus, these two effects tend to be offsetting and the effect of $\mathrm{NO}_{\mathrm{X}}$ in the flue gas could increase or decrease re-emission.

Several potential FGD additives have been identified, such as carboxylic acids, which accelerate elemental mercury re-emissions. Some carboxylic acids are currently used as $\mathrm{SO}_{2}$ removal performance additives in limestone wet FGD systems. Several other additives have been 
identified which decrease elemental mercury re-emissions, in some cases significantly. However, some of these additives may accelerate re-emissions under some conditions, and thus must be applied with caution.

A chemical kinetics model has been developed to describe the aqueous mercury-sulfite-chloridethiosulfate system and takes into account the simultaneous occurrence of a number of reaction steps. The model predicts the basic trends seen experimentally for $\mathrm{pH}$, sulfite, and chloride effects, and gives reasonably good numerical agreement with experimental data. It has been used to correlate bench-scale experimental results as well as to predict kinetics in low $\mathrm{pH}$ regions, such as at the $\mathrm{SO}_{2}$ gas-aqueous interface, which are difficult to investigate experimentally.

The results from this project can be used to make several observations as to what FGD conditions would tend to favor or minimize re-emissions:

- Limestone forced oxidation systems - In systems that produce wallboard-grade gypsum, the most advantageous mode of operation (notwithstanding mercury control) is typically at high oxidation air rates to minimize liquor sulfite concentrations in the reaction tank, at as low a $\mathrm{pH}$ set point as can achieve the desired $\mathrm{SO}_{2}$ removal percentage, and with relatively high blow down rates to keep liquor chloride concentrations down. These have the benefits of ensuring $100 \%$ sulfite oxidation in the FGD solids, ensuring high gypsum purity, and helping meet gypsum chloride concentration specifications, respectively. However, the results of this project suggest that mercury re-emissions could be minimized by operating at higher sulfite and chloride concentrations. Thus, perhaps the sulfite should be controlled no lower than is needed to ensure $100 \%$ oxidation in the byproduct solids, and the chlorides controlled at as high a concentration as the materials of construction allow and at which gypsum chloride content limits can be met. The relationship between sulfite concentration, $\mathrm{pH}$ and re-emissions appears to be complex. The $\mathrm{pH}$ set point may also have to be optimized for the target sulfite concentration to achieve the best compromise between gypsum purity and mercury re-emissions.

- Low oxidation (sulfite producing) systems - Low oxidation systems should benefit from the resulting elevated sulfite concentrations in the FGD liquor and their effects in lowering re-emission rates. In limestone-based FGD systems that operate at approximately $\mathrm{pH} 6$ or lower, the use of thiosulfate to inhibit sulfite oxidation may have benefits in lowering re-emission rates, particularly in the absorber where the $\mathrm{pH}$ drops. For lime-based systems that operate at a reaction tank $\mathrm{pH}$ above 6.0, thiosulfate addition may have an adverse effect on re-emissions. Re-emissions may be greater at reaction tank conditions with thiosulfate added, but could be reduced in the absorber where the droplet $\mathrm{pH}$ is lower.

- $\quad$ SCR effects - Having an SCR operate upstream of an FGD system could lead to competing impacts on re-emissions. If the SCR markedly increases mercury oxidation upstream of the FGD system, it could lead to greater oxidized mercury capture in the wet FGD absorber. This in turn could lead to higher liquid-phase mercury concentrations in the FGD liquor and corresponding increases in re-emissions, as re-emissions have been 
determined to be a function of liquid-phase mercury concentration. However, the corresponding reduction in $\mathrm{NO}_{\mathrm{X}}$ concentrations in the FGD inlet gas should lead to significantly lower concentrations of sulfur-nitrogen species in the FGD liquor. This should correspondingly lower re-emission rates. Further work would be needed to develop rate data to predict how these effects trade off for a particular circumstance. Field data indicate that at least for some SCR/wet FGD combinations, having the SCR in operation tends to lower re-emissions.

- Re-emissions control additives - The results from this investigation show several commercially available additives with promise for controlling re-emissions. For some additives (e.g., TMT-15) these results suggest that the additive dosage should be the minimum required to limit re-emissions; higher dosages can lead to direct reduction of mercury by the additive before it acts to limit re-emissions by precipitating the mercury.

However, it should be noted that these findings are based on project results and reflect benchscale FGD operation in a synthetic flue gas and in mostly sodium-based scrubbing solutions. Impurities in an actual flue gas environment such as from fly ash removed by the scrubber and from the dissolution of limestone reagents may impact these findings. Also, as shown in this report operation in a high-calcium environment rather than a high-sodium environment may affect the re-emissions chemistry. EPRI is funding additional work in the coming year to investigate these effects. 


\section{INTRODUCTION}

This document is the final report for Cooperative Agreement DE-FC26-04NT42314, "Kinetics Study of Mercury Reactions in FGD Liquors." The project has been co-funded by the U.S. DOE National Energy Technology Laboratory and EPRI.

The objective of the project has been to determine the mechanisms and kinetics of the aqueous reactions of mercury absorbed by wet flue gas desulfurization (FGD) systems, and develop a kinetics model to predict mercury reactions in wet FGD systems. The model may be used to determine optimum wet FGD design and operating conditions to maximize mercury capture in wet FGD systems.

A series of bench-top, liquid-phase reactor tests have been conducted and mercury species concentrations measured by ultraviolet (UV)/visible light spectroscopy to determine reactant and byproduct concentrations over time. Other measurement methods, such as atomic absorption, have been used to measure concentrations of species that cannot be measured by UV/visible light spectroscopy, such as elemental mercury as it is released from the liquid phase due to reemission reactions. These data have been used to develop an empirically adjusted, theoretically based kinetics model to predict mercury species reactions in wet FGD systems. The model has been verified in tests conducted with a bench-scale wet FGD system, where both gas-phase and liquid-phase mercury concentrations were measured to determine if the model accurately predicts the tendency for mercury re-emissions. The model has been run over a wide range of potential wet FGD design and operating conditions to determine its ability to match bench-scale wet FGD test results and to identify conditions that maximize mercury capture and minimize mercury re-emissions.

The remainder of this report is divided into four sections: a section that describes Experimental procedures, then sections for Results and Discussion, Conclusions, and References. 


\section{EXPERIMENTAL}

This project was divided into four tasks: Task 1: Project Planning; Task 2: Kinetic Data Gathering and Initial Model Development; Task 3: Model Refinement, Bench-scale Validation and Additive Testing; and Task 4: Reporting and Project Management. Of these, only Tasks 2 and 3 involved experimental work. The experimental equipment and approach for Tasks 2 and 3 are discussed in separate subsections below.

\section{Task 2: Kinetic Data Gathering and Initial Model Development}

This project focused on obtaining kinetic data under conditions common to wet FGD systems in such a way that effects of individual composition and physical variables can be determined. $\mathrm{SO}_{2}-$ derived species such as the various forms of "sulfite" are important since this is the main source of reductant for converting oxidized mercury to elemental mercury. Kinetic measurements have been made for solutions containing chloride and thiosulfate, both of which may form strong complexes with $\mathrm{Hg}^{+2}$. Another important variable is $\mathrm{pH}$, which affects both the distribution of sulfite species and the kinetics of many reactions. Most of the testing has been conducted with sulfite and chloride added as sodium salts, to avoid potential interferences from complexes that calcium and magnesium ions can form with these species. However, the effects of other major species in FGD liquors, such as magnesium, calcium, sulfate and $\mathrm{NO}_{\mathrm{X}}$-derived species, and possible catalytic effects of particulate matter, were also determined later as part of Task 3 .

In addition to chemical species effects, the effects of temperature and ionic strength on kinetics were measured in Task 2. Most of the work was done in the normal FGD temperature range (50$55^{\circ} \mathrm{C}$ ), but activation energies were measured or estimated as necessary for modeling.

Ionic strength is related to the total concentration of dissolved, ionic species in the liquor. Determining ionic strength effects is often helpful for determining reaction mechanisms and for modeling. The rate of reaction in a solution can be increased, decreased, or unchanged with increasing ionic strength, depending on whether the reactants in a rate-determining reaction step have the same or an opposite charge, or if one reactant is uncharged. Ionic strength dependence is normally determined by measuring rate constants as a function of added electrolyte concentration, using non-complexing electrolytes such as sodium perchlorate $\left(\mathrm{NaClO}_{4}\right)$.

The following subsections describe the apparatus used to conduct these experiments.

\section{UVIVis Spectrophotometer}

Prior research has shown that key Hg-sulfite species have intense absorption peaks in the ultraviolet (UV) range and thus can be monitored as a function of time by taking periodic spectral measurements. Instrumentation used on this project allowed rapid gathering of complete $\mathrm{UV} /$ visible (vis) spectra (up to 50 spectra per second) or monitoring light absorbance at up to six wavelengths simultaneously as desired. This greatly enhanced the ability to obtain both pathway information (by following multiple peaks in the spectra) and kinetics data for construction of a meaningful model. 
The experimental apparatus for following aqueous reactants at low concentrations consists of a stirred spectrophotometric cell housed in a special cell holder which provides precise temperature control, stirring, inert gas flow as required, and fiber optic hookups to a UV/vis light source and a CCD spectrometer. The spectrometer and cell holder are computer controlled, enabling precise control and rapid sampling. Figure 1 is a photograph of the bench-top spectrophotometric equipment.

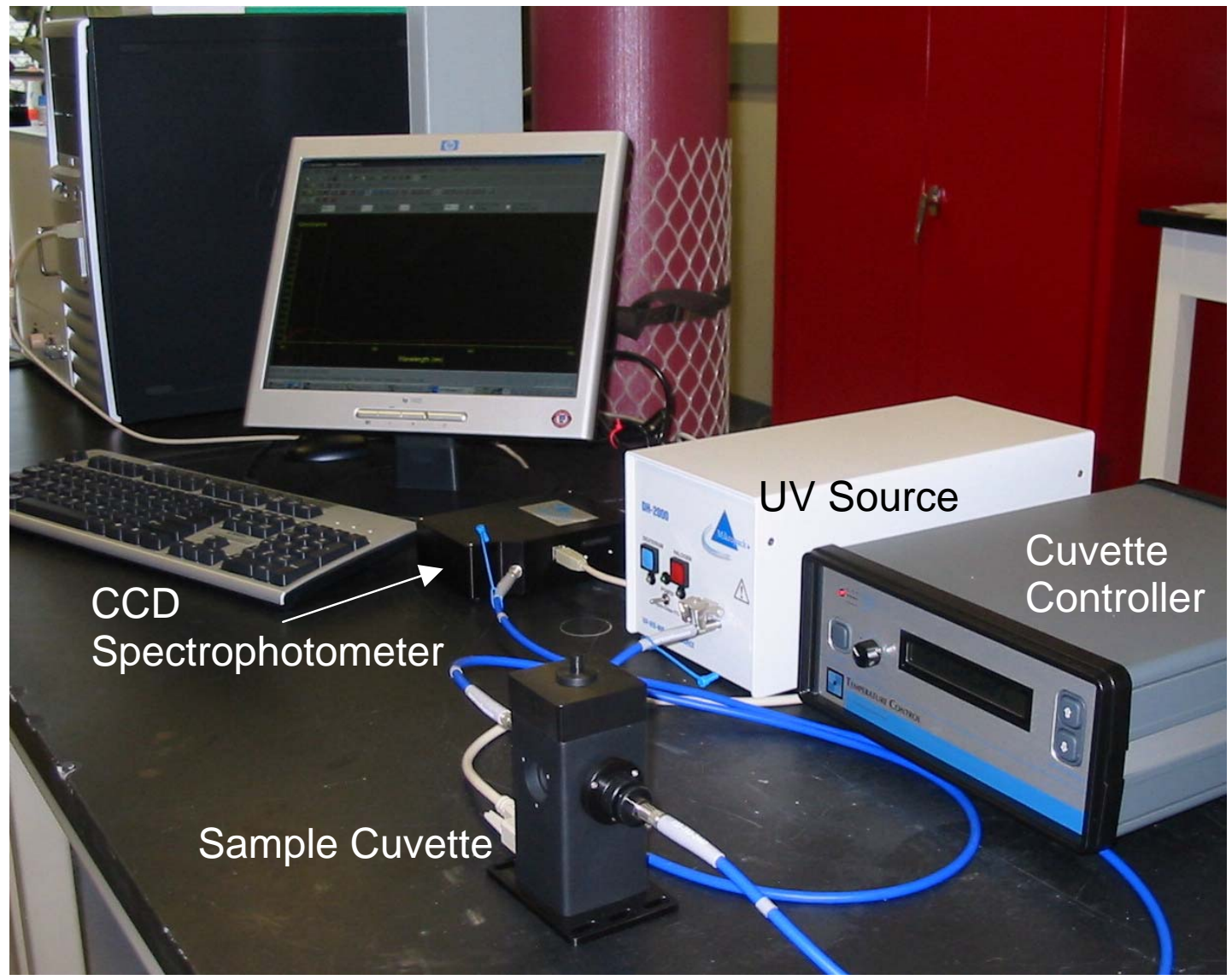

Figure 1. Photo of UVIVis Spectrometer and Cell Holder Apparatus

The spectrophotometric system used for kinetics measurements is built around an Ocean Optics HR2000 high-resolution miniature fiber optic spectrometer, which includes a Sony ILX511 linear CCD array detector. The spectrometer interfaces to the main computer. It is capable of providing full spectrum scans into memory every 13 milliseconds and has an integration time variable from 3 milliseconds to 65 seconds. The high resolution of the optical bench of this spectrometer is provided by an expanded 1-inch diameter, 4-inch focal length (f/4) design in a symmetrical crossed Czerny-Turner optical design.

The optical system uses an Ocean Optics DT-1000 deuterium tungsten halogen light source, which combines the continuous spectrum of a deuterium UV light source and a tungsten halogen Vis/shortwave near-infrared light source into a single optical path. The combined-spectrum light source produces a stable output from $\sim 200-1100 \mathrm{~nm}$. The output is coupled to a fiber optic for transmission to the cuvette (measurement cell) holder. 
This kinetics work used a Quantum Northwest TLC 50F TM fiber optic temperature-controlled cuvette holder in conjunction with the spectrometer and light source. The computer-controlled cuvette holder provides precise temperature control of the $1-\mathrm{cm}$ cuvette reaction vessel, built-in magnetic stirring, a dry gas purge to limit condensation or exclude oxygen from the cuvette, and optical slits for control of the illuminated volume.

The package includes a Quantum Northwest TC 101 microprocessor-controlled temperature controller and is calibrated against a NIST-traceable thermometer. It uses a Peltier device for temperature control and is capable of maintaining the cuvette temperature at -40 to $+105^{\circ} \mathrm{C}$ $\pm 0.02^{\circ} \mathrm{C}$.

Since the reactions studied have been relatively slow, a simple but effective manual mixing method has been used to obtain kinetics data. Typically $2.00 \mathrm{~mL}$ of solution containing mercuric perchlorate and a $\mathrm{pH}$ buffer is placed in the spectrophotometric cell and temperature equilibrated in the cuvette holder. Continuous acquisition of spectra is initiated, typically taking a complete spectrum every five seconds. About 10 spectra are obtained for background subtraction purposes, then a small amount of sulfite solution is injected into the stirred spectrophotometric cell to start the reaction (typically $20-50$ microliter $[\mu \mathrm{L}]$ using a microliter pipetter). This addition results in the abrupt appearance of a peak in the $230-235 \mathrm{~nm}$ region due to formation of mercuric disulfite, the predominant aqueous complex formed between mercury ion and sulfite ion. The decay of this peak is then monitored by continuing to take spectra for up to several hours.

\section{Macro Cell}

As the project progressed, a "macro cell" was constructed and checked out as an experimental enhancement as well as check on some of the previous "micro" scale (2-mL reaction volume) UV absorbance results. This cell is designed to allow simultaneous and continuous measurement of UV absorbance, open circuit potential (OCP, or "redox potential"), $\mathrm{pH}$, and temperature. In the previous micro cell, only UV absorbance and temperature could be monitored. The volume of this cell is large enough $(100 \mathrm{~mL})$ to allow periodic sampling during a run with subsequent measurement of sulfite/sulfate by ion chromatography. A photograph of the cell and ancillary equipment is shown in Figure 2.

\section{AA Spectrophotometer}

In unraveling complex chemical kinetics, it is important to measure as many of the participating chemical species as possible, including both reactants and products. Therefore, tests have been done which measure the evolution of $\mathrm{Hg}^{0}$ from solution both by making gas phase mercury $(\mathrm{Hg})$ measurements on the outlet gas and measuring the amount of total mercury remaining in a continuously sparged solution. The test apparatus for this procedure consists of a reaction vessel (sparger) charged with an aqueous solution containing a buffer for $\mathrm{pH}$ control and other chemical species, such as chloride, as desired. A gas stream containing nitrogen, $\mathrm{SO}_{2}$, and presaturated with water is passed through this solution at a constant rate, typically $1.0 \mathrm{~L} / \mathrm{min}$. The $\mathrm{SO}_{2}$ concentration in the gas and $\mathrm{pH}$ are chosen to give the desired $\mathrm{SO}_{2}$ (sulfite species) concentration in the liquid. 


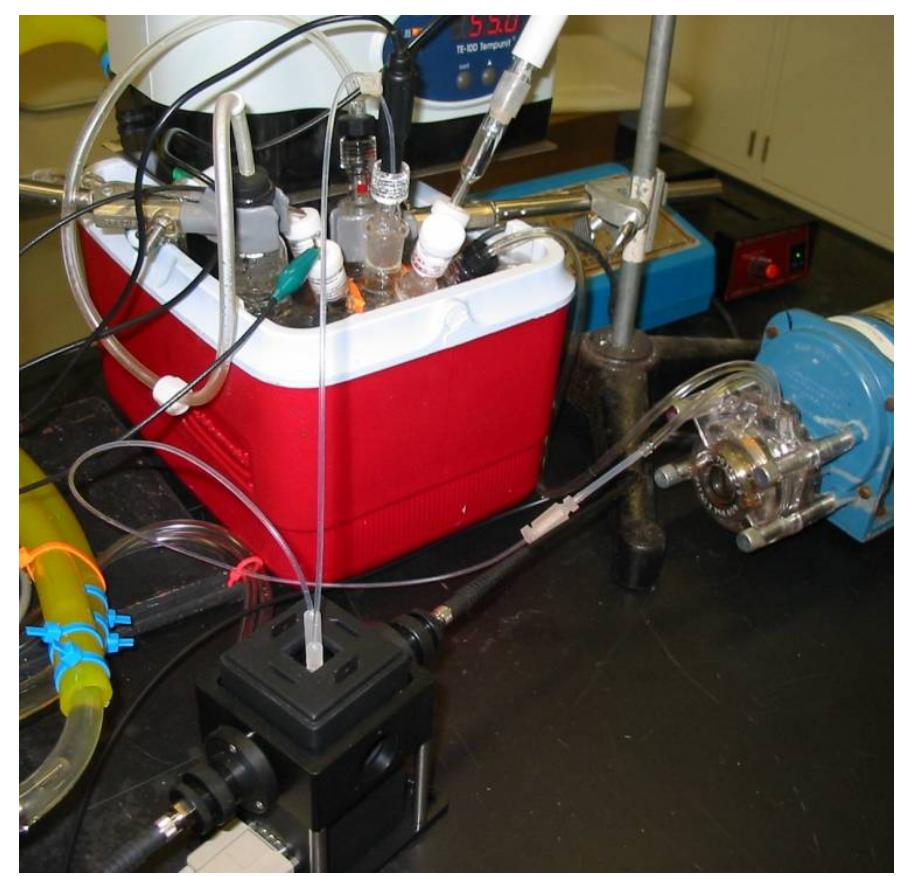

Figure 2. Multi-port Reaction Cell in Thermostatted Bath Showing Pumping to External Thermostatted Spectrophotometric Cell

The sparged reaction vessel is submerged in a water bath temperature controlled to $\pm 0.1^{\circ} \mathrm{C}$. To start the reaction a solution containing mercuric ion is injected into the sparged solution via a hypodermic syringe and septum. Elemental mercury sparged from the reaction vessel is measured using a UV gas cell spectrophotometer and a $254 \mathrm{~nm}$ mercury lamp (an atomic absorption analyzer) as a function of time using computer controlled data acquisition. Alternatively, for slow reaction rate conditions the liquid phase is periodically sampled and the preserved solutions analyzed for mercury with a Perkin Elmer FIMS analyzer (cold vapor atomic absorption).

\section{Task 3: Model Refinement, Bench-scale Validation and Additive Testing}

The kinetics data collected as part of this project have been used to develop an empirically adjusted, theoretically based kinetics model to predict mercury species reactions in wet FGD systems. The model was verified in tests conducted with a bench-scale wet FGD system, where both gas-phase and liquid-phase mercury concentrations are being measured to determine if the model accurately predicts the tendency for mercury re-emissions. The bench-scale wet FGD system is described below.

\section{Bench-scale Wet FGD System}

Prior to beginning this project, an existing bench-scale wet scrubber was modified to add a new absorber vessel with an integral reaction tank, and a magnetic agitator drive for the reaction tank 
to allow the tank to be tightly sealed. Figure 3 illustrates the revised $24 \mathrm{~L} / \mathrm{min}$ bench-scale scrubber used in the Task 3 bench-scale wet FGD simulation testing.

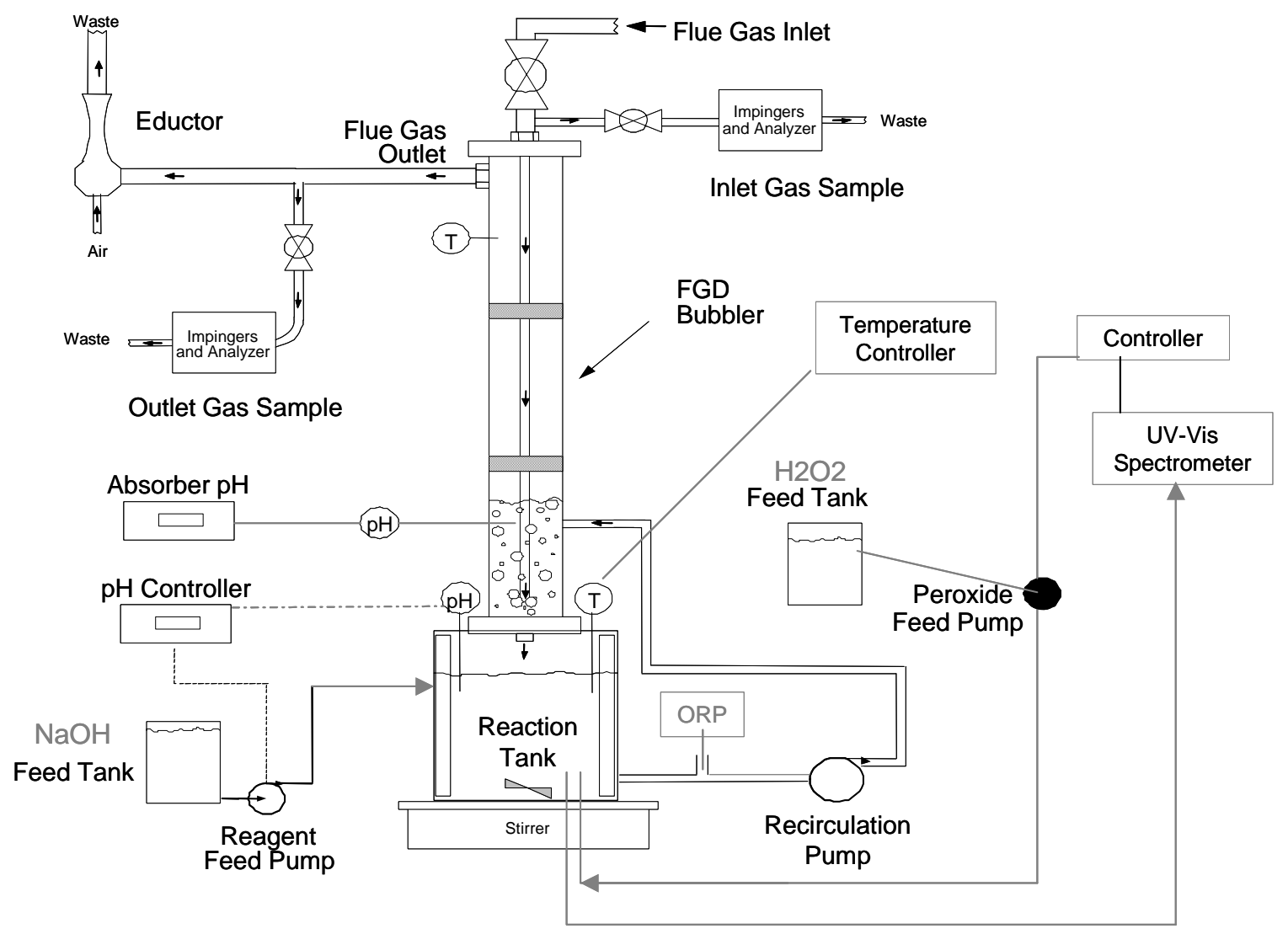

Figure 3. Bench-scale FGD Apparatus

Simulated flue gas is mixed from a variety of compressed gases using calibrated rotameters. Figure 4 shows the simulation gas mixing apparatus. The dry simulation gas typically contains $\mathrm{SO}_{2}, \mathrm{NO}_{\mathrm{X}}, \mathrm{HCl}, \mathrm{CO}_{2}$, oxygen, and nitrogen. Moisture is added to the simulation gas by feeding the oxygen, $\mathrm{CO}_{2}$, and a portion of the dry nitrogen gas through a water saturator, which is maintained at a predetermined pressure and temperature to achieve the desired humidity level in the wet gas mixture.

Oxidized (or elemental) mercury is added to the gas by passing a portion of the dry nitrogen gas makeup through a mercury diffusion cell. The diffusion cell contains either an elemental mercury permeation tube or mercuric chloride $\left(\mathrm{HgCl}_{2}\right)$ crystals maintained at an elevated temperature. For these runs the simulation gas is spiked only with oxidized mercury from $\mathrm{HgCl}_{2}$ crystals.

In actual practice, the oxidized mercury source produces a small amount of elemental mercury in the simulation gas; about $5 \%$ of the total mercury in the flue gas entering the scrubber is in the elemental form. Four parallel mercury diffusion cells, each containing mercuric chloride crystals, provide the mercury content of the simulation gas. 


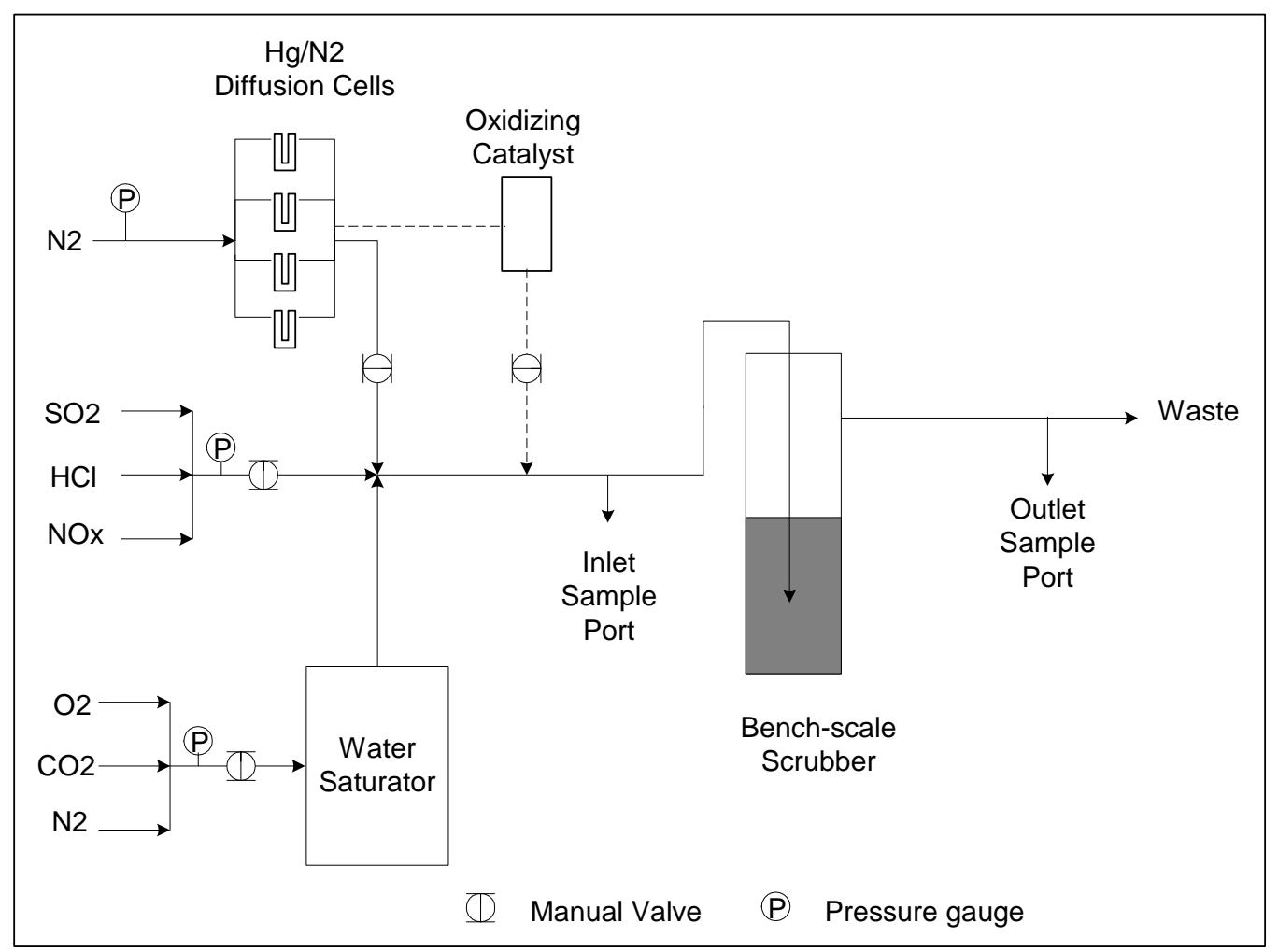

Figure 4. Bench-scale Simulation Gas Mixing Apparatus

The wet scrubber uses a "bubbler" type gas contactor similar to a Chiyoda jet bubbling reactor (JBR). Low slurry levels in the bubbler simulate conventional spray or tray contactors (e.g., 4 in. $\mathrm{H}_{2} \mathrm{O}[1 \mathrm{kPa}$ gas pressure drop) and high slurry levels can be used to simulate a high-energy venturi scrubber (e.g., 15 in. $\mathrm{H}_{2} \mathrm{O}$ [3.7 kPa] gas pressure drop). However, the normal motive force for the flow through the scrubber is the pressure of the simulation gases, so the scrubber outlet pressure is slightly positive.

A stirred reaction tank is situated directly below and integrally mounted to the gas contactor. Solution from the reaction tank is pumped into the contactor to maintain solution level in the bubbler and to establish the desired liquid-to-gas ratio $(\mathrm{L} / \mathrm{G})$; spent solution returns to the reaction tank by gravity flow. For the clear liquid tests, sodium hydroxide solution is added to the reaction tank as needed to control $\mathrm{pH}$ at the set point value. A $\mathrm{pH}$ controller cycles the reagent makeup pump as needed. The bench-scale apparatus is heat traced, insulated and is controlled to typical full-scale wet scrubber temperatures.

The simulated flue gas delivery system to the bench scale wet FGD system is designed to avoid mercury loss and contamination. A heat-traced simulation gas delivery line allows the use of replaceable teflon tubing (to deal with any potential mercury contamination), and all fittings and valves in the system are either teflon or quartz components. 


\section{Flue Gas Measurements}

Mercury measurements are made using two mercury semi-continuous emissions monitors (SCEMs) developed for EPRI, as illustrated in Figure 5. In the analyzer, flue gas is pulled from the bench-scale scrubber inlet or outlet gas at about $1 \mathrm{~L} / \mathrm{min}$ through a series of impinger solutions using a Teflon-lined pump.

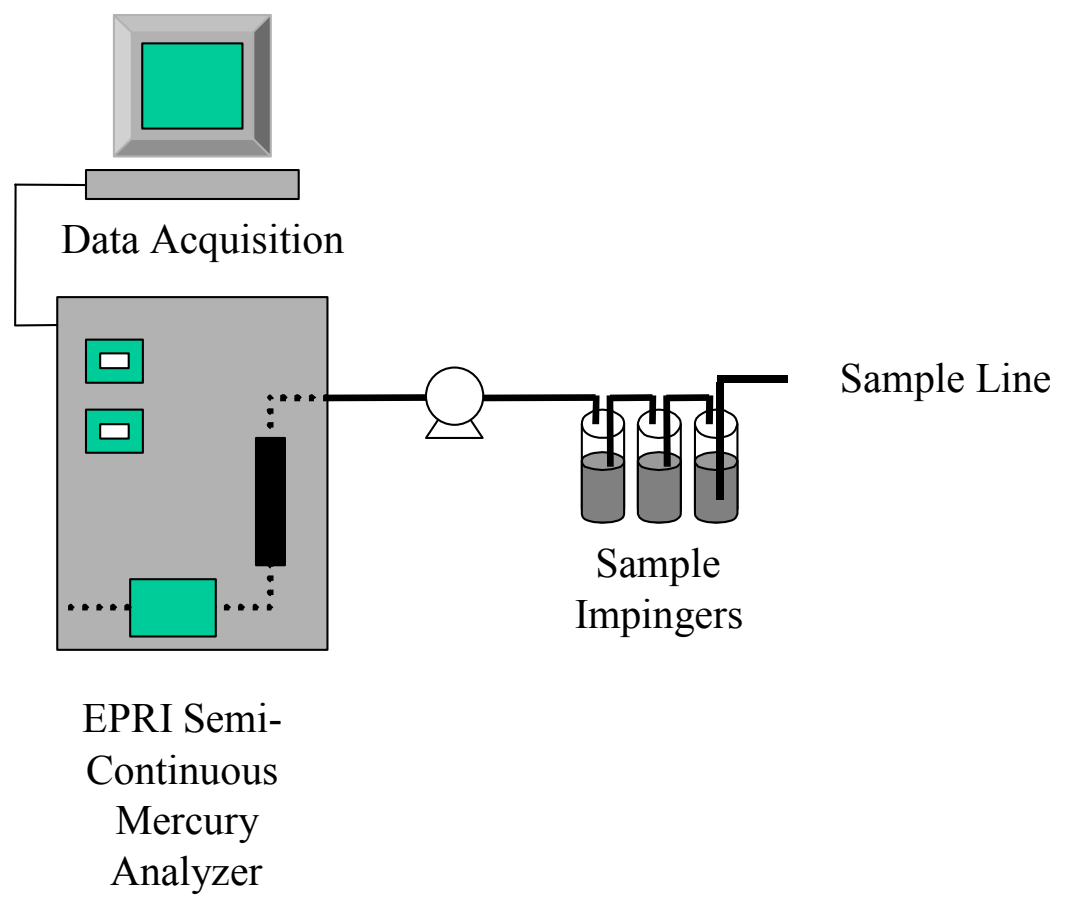

Figure 5. Schematic of Mercury SCEM

To measure total mercury in the flue gas, these impinger solutions consist of stannous chloride $\left(\mathrm{SnCl}_{2}\right)$ followed by a sodium carbonate $\left(\mathrm{Na}_{2} \mathrm{CO}_{3}\right)$ buffer and sodium hydroxide $(\mathrm{NaOH})$. The $\mathrm{SnCl}_{2}$ solution reduces all flue gas mercury species to elemental mercury. After passing through the $\mathrm{SnCl}_{2}$ impinger, the gas flows through the $\mathrm{Na}_{2} \mathrm{CO}_{3}$ and $\mathrm{NaOH}$ solutions to remove acid gases, thus protecting the downstream, analytical gold surface. Gas exiting the impinger solutions flows through a gold amalgamation column where the mercury in the gas is adsorbed at less than $100^{\circ} \mathrm{C}$. After adsorbing mercury onto the gold for a fixed period of time (typically 1 to 5 minutes), the mercury concentrated on the gold is thermally desorbed $\left(>700^{\circ} \mathrm{C}\right)$ from the column into nitrogen. The desorbed mercury is sent as a concentrated stream to a cold-vapor atomic absorption spectrophotometer (CVAAS) for analysis. The total flue gas mercury concentration is measured semi-continuously, typically with a one- to five-minute sample time followed by a one- to two-minute analytical period.

To measure elemental mercury in the flue gas, the stannous chloride impinger is replaced with an impinger containing either tris(hydroxymethyl)aminomethane (Tris) or potassium chloride $(\mathrm{KCl})$ solution. The Tris solution has been shown in other EPRI studies to capture oxidized mercury while allowing elemental mercury to pass through without being altered. ${ }^{1} \mathrm{KCl}$ is used to collect oxidized mercury in the Ontario Hydro train. Mercury passing through the Tris or $\mathrm{KCl}$ solution to the gold is analyzed as described above and assumed to be elemental mercury only. The 
difference between the total mercury concentration (stannous chloride solution) and elemental mercury concentration (Tris or $\mathrm{KCl}$ solution) is assumed to be the oxidized mercury concentration.

Two analyzers are used to semi-continuously monitor scrubber inlet and outlet gas mercury concentrations. The analyzers are switched intermittently between sampling for elemental versus total mercury concentrations.

$\mathrm{SO}_{2}$ detection tubes are also used periodically during the testing, to quantify $\mathrm{SO}_{2}$ removal across the bench-scale absorber. Overall $\mathrm{SO}_{2}$ removal levels are typically $90 \%$ or greater. Aliquots of the scrubber liquor are removed from the reaction tank periodically, and analyzed by iodometric titration to determine sulfite ion concentrations. For each test condition a set of slurry and preserved FGD liquor samples is collected and analyzed to document the end-of-test scrubber chemistry conditions.

\section{Bench-scale Wet FGD Operation}

Modifications to the existing bench-scale wet FGD apparatus were determined to be necessary because of the complex relationship between $\mathrm{pH}$, sulfite concentration and chloride concentration on mercury re-emissions. Of these, chloride concentration is the most readily controlled. Since chloride is a highly soluble ion, it tends to cycle up in concentration in the FGD liquor over time in FGD systems that operate with a closed or nearly closed water loop, as do most wet FGD systems. Thus, most bench-scale wet FGD runs are conducted by spiking the reaction tank liquor to simulated steady-state chloride concentrations. The chloride absorbed into the liquor from $\mathrm{HCl}$ in the simulation gas has only a minor effect on liquor chloride concentrations, so the chloride concentration is predominantly controlled by the initial spiking level.

At a given set of inlet flue gas and FGD liquor dissolved species conditions, the liquor $\mathrm{pH}$ is controlled by reagent addition to the reaction tank. The $\mathrm{pH}$ of the reaction tank slurry liquor is continuously monitored and used to start and stop a reagent makeup pump. However, for mercury re-emissions, it may be the $\mathrm{pH}$ of the slurry liquor in the absorber rather than in the reaction tank that is most important. Consequently, a second $\mathrm{pH}$ meter was added to monitor the slurry liquor $\mathrm{pH}$ in the absorber. Testing indicated that the absorber $\mathrm{pH}$ can be controlled indirectly by controlling the reaction tank $\mathrm{pH}$ set point at an appropriate higher value. All tests have been conducted by control of the reaction tank $\mathrm{pH}$, and it is the reaction tank $\mathrm{pH}$ that is represented in data tables and plots.

FGD liquor sulfite concentration is typically not controlled, except when operating in a limestone/forced oxidation mode where it is controlled to very low concentrations with the oxidation air rate. In natural or inhibited oxidation modes, the sulfite concentration is a function of the inlet flue gas $\mathrm{SO}_{2}$ concentration; liquor $\mathrm{pH}$; concentrations of other species in the FGD liquor, including transition metal catalysts; FGD solids surface area; and sulfite oxidation rates. For a given set of run conditions, the inlet $\mathrm{SO}_{2}$ concentration, $\mathrm{pH}$, concentrations of other species in the FGD liquor, and FGD solids surface area (if solids are present) are set by test conditions. This leaves sulfite oxidation rate as the sole remaining variable that can be used to control FGD liquor sulfite concentration. 
We initially tried to control the sulfite oxidation rate and thus the liquor sulfite concentration by varying the amount of oxygen fed to the bench-scale FGD inlet simulation gas. To minimize total gas flow variations as the oxygen concentration varied, the simulation gas oxygen content was changed to being introduced by pure $\mathrm{O}_{2}$ rather than air as previously used. Since we did not (initially) have a real time sulfite analyzer, we tried using the oxidation-reduction potential (ORP) as a surrogate for controlling sulfite concentration. This was not successful because the ORP was not a reliable indicator of sulfite concentration or often even of the trend of sulfite concentration. In conducting these initial runs, however, we developed a spectrophotometric method, based on a literature method, ${ }^{2}$ to measure sulfite quickly. It was quite successful, enabling results to be obtained in only few minutes and requiring only a few milliliters of solution, instead of the rather large sample requirement and tedious nature of the usual iodimetric titration for sulfite concentration.

We used an oxidation catalyst $\left(\mathrm{MnSO}_{4}\right.$ at $0.01 \mathrm{mM}$ loading) to try to stabilize the rate of sulfite oxidation, which is known to be highly dependent on the presence of catalytic materials. However, we still had a great deal of difficulty obtaining steady sulfite levels, apparently due to the highly variable rate of sulfite oxidation by oxygen. The oxidation rate seemed to vary from very sluggish, producing high sulfite levels, switching to very fast as perhaps some critical intermediate concentration was obtained, forcing low sulfite concentrations. Thus extreme oscillations in sulfite were often obtained even with close manual monitoring and control of oxygen flow.

Therefore we decided to use hydrogen peroxide $\left(\mathrm{H}_{2} \mathrm{O}_{2}\right)$ instead of oxygen for oxidizing sulfite. The reaction of sulfite with $\mathrm{H}_{2} \mathrm{O}_{2}$ is apparently quite fast and not subject to the temporal variations we observed with oxygen. We believe that the use of $\mathrm{H}_{2} \mathrm{O}_{2}$ is justified since it is a "natural product" of the reduction of oxygen to water in any case. The spectrophotometric method for sulfite was modified to make it a real time measurement by adding a flow-through spectrophotometric cell, peristaltic pumps for sampling and reagent addition, and a digital controller. The controller meters a dilute $\mathrm{H}_{2} \mathrm{O}_{2}$ solution to the reactor as dictated by the sulfite concentration. Stable sulfite concentrations can be maintained fairly consistently with this method.

As described later in this report, most of the bench-scale wet FGD tests have been conducted in a sodium-based, clear liquor solution to allow precise control of sulfite concentrations, and to avoid solid interactions with the chemistry except under controlled conditions. The FGD sorbent solution is made up as a mixture of $\mathrm{NaCl}, \mathrm{Na}_{2} \mathrm{SO}_{4}, \mathrm{MnSO}_{4}$, and mercuric ion added as mercury perchlorate $\left[\mathrm{Hg}\left(\mathrm{ClO}_{4}\right)_{2}\right]$ after steady conditions reached. During each run, hydrogen peroxide is added for sulfite control, and sodium hydroxide $(\mathrm{NaOH})$ solution for $\mathrm{pH}$ control.

The simulated flue gas includes $\mathrm{CO}_{2}$, moisture, $\mathrm{O}_{2}, \mathrm{SO}_{2}, \mathrm{HCl}, \mathrm{HgCl}_{2}$ (with a small amount of elemental mercury contained), and the balance moisture. The total flow rate is typically $24 \mathrm{~L} / \mathrm{min}$ (dry basis).

Typically the scrubbing solution is made up with all ingredients except $\mathrm{Hg}\left(\mathrm{ClO}_{4}\right)_{2}$ added, brought up to temperature in the reaction vessel, acid gases started, and $\mathrm{MnSO}_{4}$ and $\mathrm{Na}_{2} \mathrm{SO}_{3}$ 
solutions added. Then "oxidized" mercury is admitted to the gas stream and its concentration determined by CVAA. The $\mathrm{pH}$ control is stabilized and when the system is at "steady-state" the injection of $0.5 \mu \mathrm{M} \mathrm{Hg}\left(\mathrm{ClO}_{4}\right)_{2}$ starts the main part of the run. Separate CVAA units are used to monitor the inlet $\mathrm{Hg}$ and the outlet $\mathrm{Hg}$ concentrations. In most cases a nearly constant difference between the inlet elemental $\mathrm{Hg}$ and the (higher) outlet elemental Hg is observed. Typically the runs show a 2- to 3-hour steady period over which the inlet and the outlet concentrations can be separately averaged and then subtracted to give what we term the "average re-emission" for the run:

Average re-emission $=[$ average elemental Hg in outlet $]-[$ average elemental $\mathrm{Hg}$ in inlet $]$

Figure 6 shows time profiles of mercury and sulfite for a typical run including preliminary setup and calibration, while Figure 7 shows an expanded scale for the steady period of main interest.

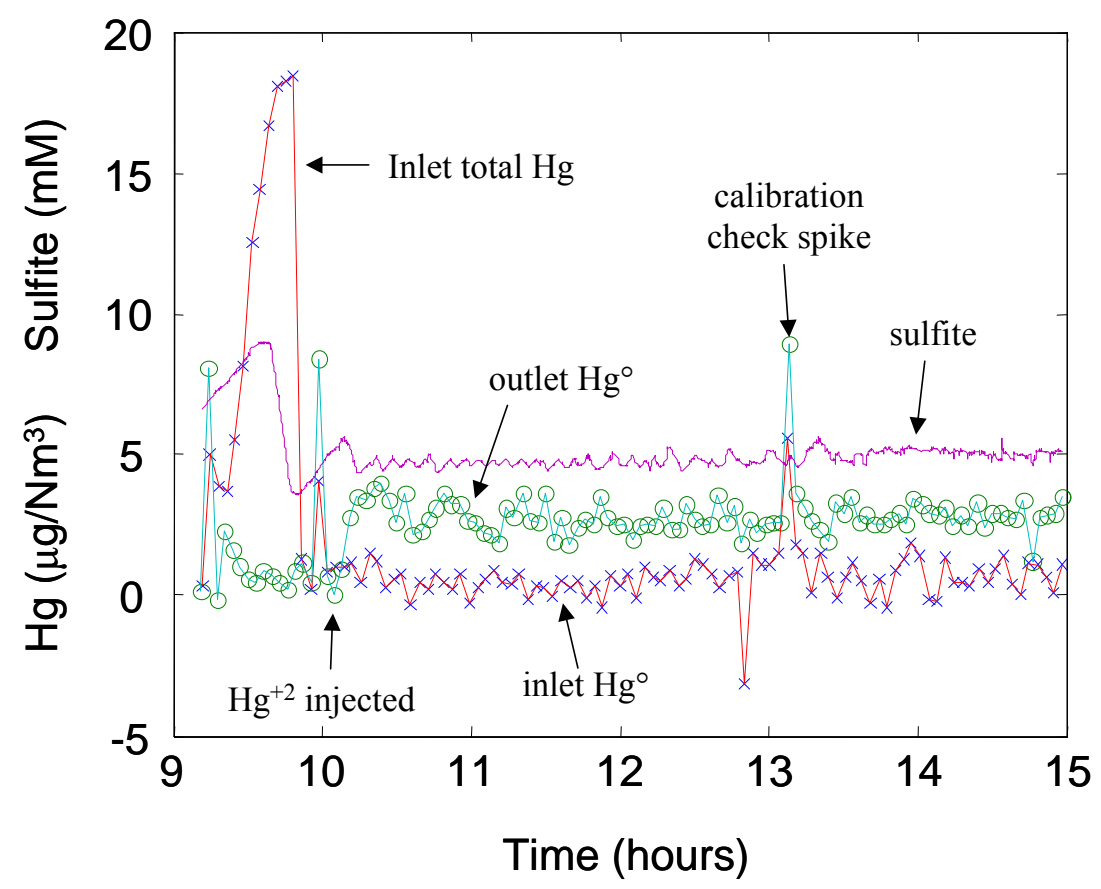

Figure 6. Time Profiles for a Typical Run Including Preliminary Setup and Calibration 


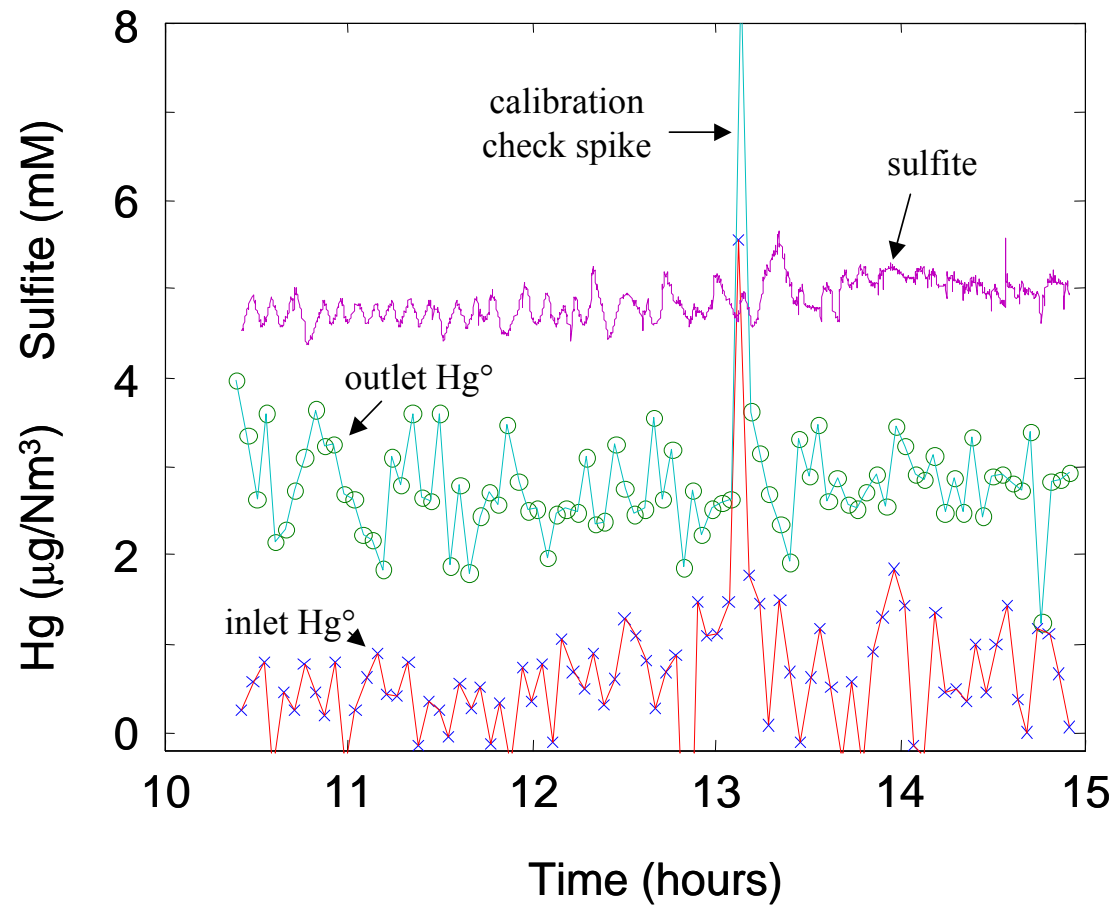

Figure 7. Example of Period for Which Re-emissions are Measured 


\section{RESULTS AND DISCUSSION}

This section presents and discusses the results from the project. The technical effort conducted as part of this project was divided into two tasks: Task 2: Kinetic Data Gathering and Initial Model Development, and Task 3: Model Refinement, Bench-scale Validation and Additive Testing. Results from each task are discussed in separate subsections below.

\section{Task 2: Kinetic Data Gathering and Initial Model Development}

The initial kinetic data gathering effort was conducted in the laboratory using UV spectroscopy to track the concentrations of key species in simulated FGD liquors and, in separate experiments, using atomic absorption to track total mercury concentrations in simulated FGD liquors or elemental mercury concentrations in gas swept across simulated FGD liquors under reacting conditions (mercury "stripping rate" tests). Results from each experimental type are discussed below.

As the Task 2 kinetic data gathering effort was being conducted, a mercury reaction kinetics model was also being developed to help explain observed results. Further refinements to the model were made as part of Task 3 , which are discussed later in the Task 3 subsection.

\section{UV Spectroscopy Results}

\section{Kinetics for Simple Solutions in the Absence of Chloride}

A broad matrix of spectrophotometric kinetics runs was completed during the first year of the project. "Raw" spectrophotometric results are shown in this subsection in terms of absorbance as a function of time. In all cases a $1.00 \mathrm{~cm}$ path length cell was used. In the absence of chloride, the absorptivity of the primary species absorbing near 230 nanometers $(\mathrm{nm})$ [mercuric disulfite complex, $\left.\mathrm{Hg}\left(\mathrm{SO}_{3}\right)_{2}{ }^{-2}\right]$ is $3.0 \times 10^{4} \mathrm{M}^{-1} \mathrm{~cm}^{-1}$, so an absorbance of 1.0 corresponds to a liquor concentration of approximately $3.3 \times 10^{-5}$ molar $\left(\mathrm{M}\right.$, or g-mol/L) of $\mathrm{Hg}\left(\mathrm{SO}_{3}\right)_{2}{ }^{-2}$. The decrease in absorbance thus corresponds to the disappearance of this species and formation of elemental mercury to re-emit as given by the overall reaction:

$$
\mathrm{Hg}\left(\mathrm{SO}_{3}\right)_{2}{ }^{-2}+\mathrm{H}_{2} \mathrm{O} \rightarrow \mathrm{Hg}^{0}+\mathrm{SO}_{4}{ }^{=}+\mathrm{HSO}_{3}{ }^{-}+\mathrm{H}^{+}
$$

Figure 8 shows an example of absorbance (at $233 \mathrm{~nm}$ ) vs. time results for the formation and decay of $\mathrm{Hg}\left(\mathrm{SO}_{3}\right)_{2}{ }^{-2}$ on mixing 0.040 millimolar $(\mathrm{mM})$ total $\mathrm{Hg}^{+2}$ with $0.23 \mathrm{mM}$ total sulfite at $\mathrm{pH} 3.0$ and $45^{\circ} \mathrm{C}^{*}$. The inset in the figure illustrates the type of spectra used to generate the plot in Figure 8, although the inset data were obtained under slightly different conditions of $0.18 \mathrm{mM}$ total sulfite. The wavelength used for the absorbance curve was selected by inspection of the peaks for each run. The peaks generally varied only over a short range of 230-234 nm during the run.

\footnotetext{
${ }^{*}$ Throughout this report, aqueous species are generally discussion in concentrations of millimolar $(\mathrm{mM})$ or micromolar $(\mu \mathrm{M})$ units. Note that a concentration of a species in $\mathrm{mM}$ units times the molecular weight of that species is approximately equal to the concentration in parts per million ( $\mathrm{ppm}$ ), which assumes the liquor specific gravity is near 1.0. Similarly, a concentration in units of $\mu \mathrm{M}$ times the molecular weight of that species is approximately equal to the concentration in parts per billion ( $\mathrm{ppb}$ ).
} 


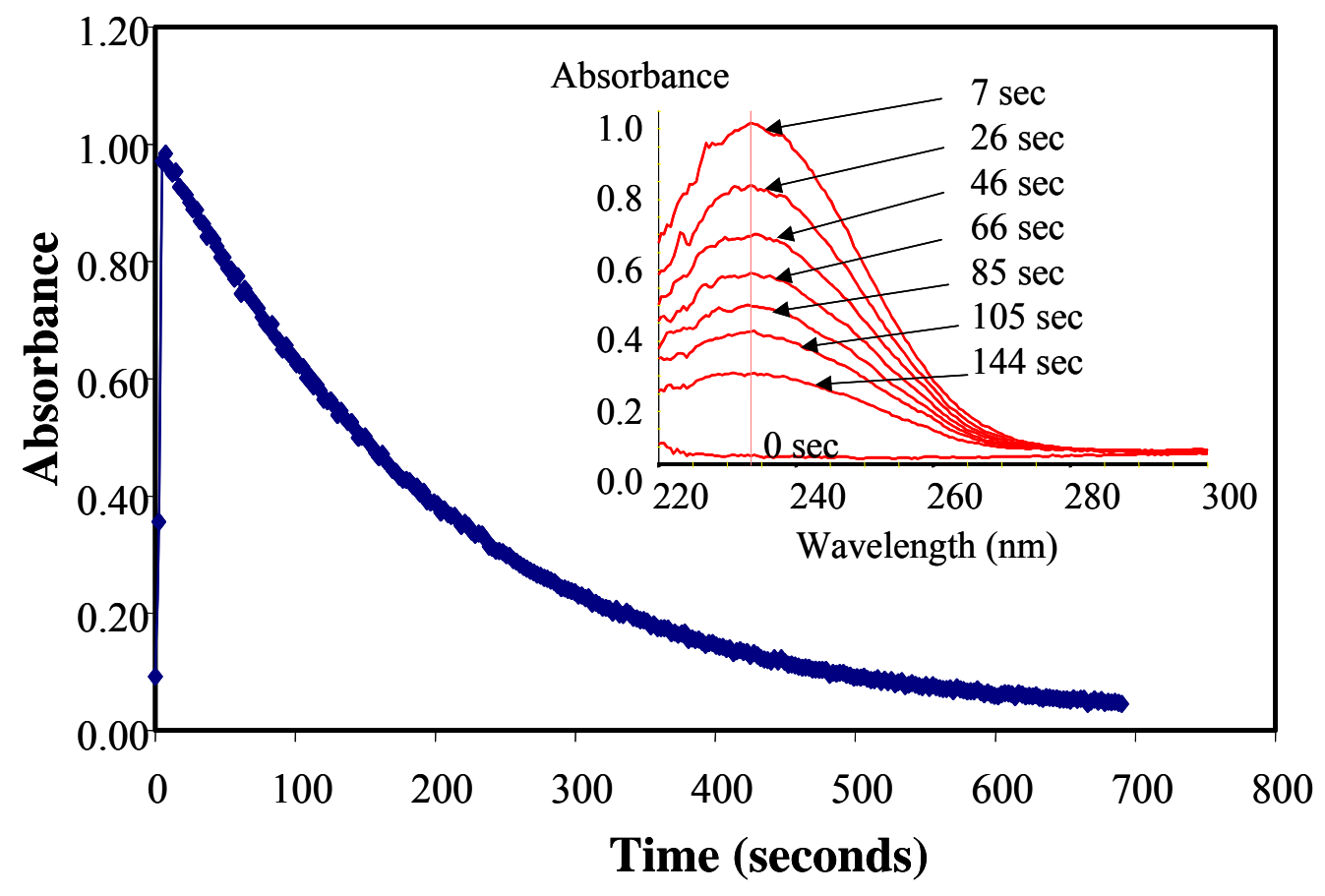

Figure 8. Experimental Absorbance and Spectra Data for Mercury Disulfite

The effect of $\mathrm{pH}$ on Reaction 2 is shown in Figure 9 for solutions without chloride at $55{ }^{\circ} \mathrm{C}$ and initially containing $1.0 \mathrm{mM}$ sulfite $(\sim 80 \mathrm{ppm})$ and 40 micromolar $(\mu \mathrm{M}) \mathrm{Hg}^{+2}(\sim 8 \mathrm{ppm})$. As shown, the rate of mercuric complex decomposition slows considerably in going from $\mathrm{pH} 3.0$ to $\mathrm{pH} 3.9$, and even more when the $\mathrm{pH}$ is adjusted to 4.9. The lower $\mathrm{pH}$ values in the figure represent the $\mathrm{pH}$ a droplet might achieve as it falls through an FGD absorber rather than a bulk reaction tank slurry $\mathrm{pH}$, which would more typically be in the range of $\mathrm{pH} 5$ to 7 .

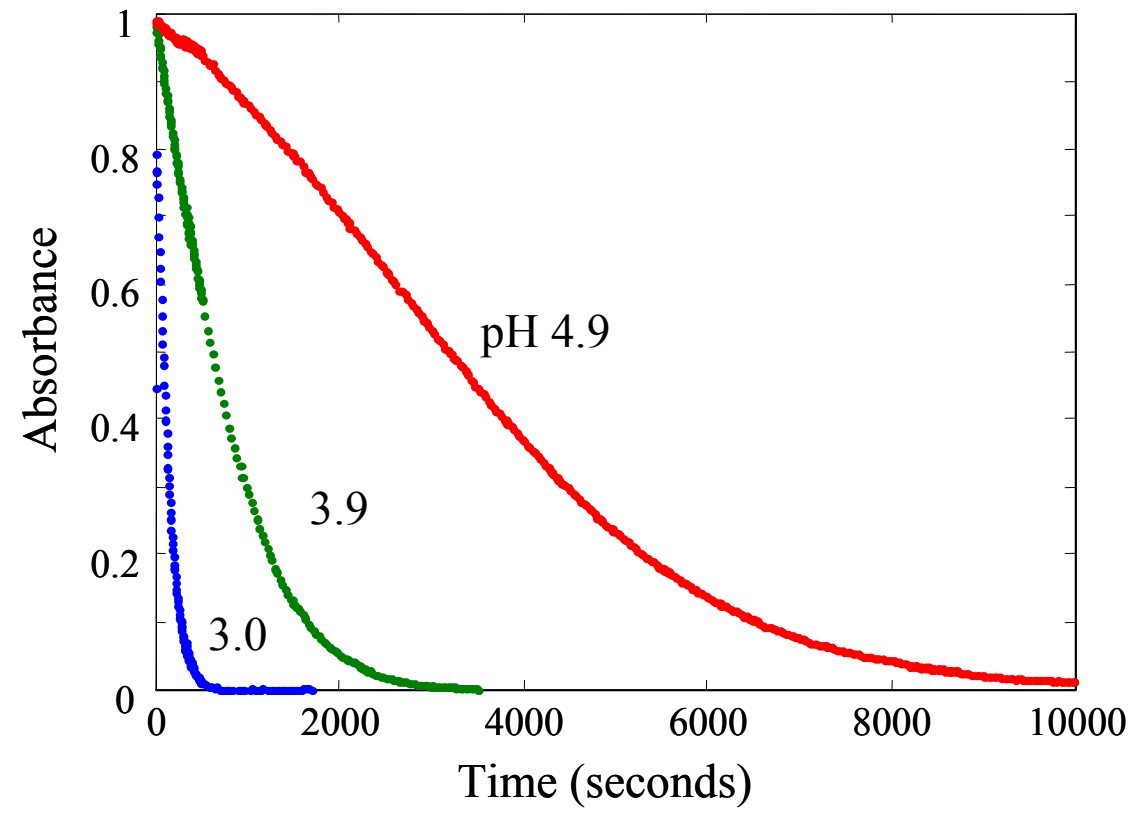

Figure 9. Effect of $\mathrm{pH}$ on Rate Curves (no chloride; $55^{\circ} \mathrm{C} ; 1.0 \mathrm{mM}$ sulfite; $40 \mu \mathrm{M} \mathrm{Hg}^{+2}$ ) 
In the $\mathrm{pH} 4.9$ case, the shape of the absorbance - time curve starts to deviate significantly from what one would expect from a simple first order reaction, which should produce more of an asymptotic decay similar to the plot in Figure 8. However, for the purposes of comparing results from run to run to quantify variable effects, an "observed" rate constant, $\mathrm{k}_{\mathrm{obs}}$, was calculated for each run assuming a simple first order reaction. This was obtained from a least squares fit of the experimental data using the equation:

$$
\ln A_{t}=\ln A_{0}-k_{o b s} t
$$

where $A_{t}$ is the absorbance as a function of time, $A_{0}$ is the initial absorbance, and $t$ is the time in seconds. A good fit to this equation was obtained only for the more "ideal" results near $\mathrm{pH} 3$ and without chloride, but even for conditions where the fit was poorer it is useful to use this value for comparison purposes. As an example, a plot of $\log \mathrm{k}_{\text {obs }}$ versus $\mathrm{pH}$ has a slope of about -0.76 , suggesting that the rate is inversely proportional to hydrogen ion concentration, in the absence of chloride and other complexing agents.

The effect of sulfite on the reaction profiles is shown in Figure 10 for solutions without chloride, at $\mathrm{pH} 3.9$ and $55^{\circ} \mathrm{C}$ and initially containing $40 \mu \mathrm{M} \mathrm{Hg}^{+2}$. The lowest sulfite concentration gives the fastest reaction rate, followed by the intermediate sulfite concentration, with the highest sulfite showing both a very slow decomposition rate and considerable departure from ideal first order behavior. A log-log plot for $\mathrm{k}_{\mathrm{obs}}$ and sulfite concentration gives a reaction order of -1.18 , suggesting that the reduction rate is inversely proportional to sulfite concentration under these conditions. This seems counterintuitive, since sulfite is a reactant in the overall reaction shown as Reaction 2. However, the explanation appears to be that in the absence of chloride, higher sulfite concentrations lead to more of the $\mathrm{Hg}^{+2}$ being present as the mercuric disulfite complex which decomposes to form elemental mercury more slowly than a monosulfite complex that forms at low sulfite concentrations.

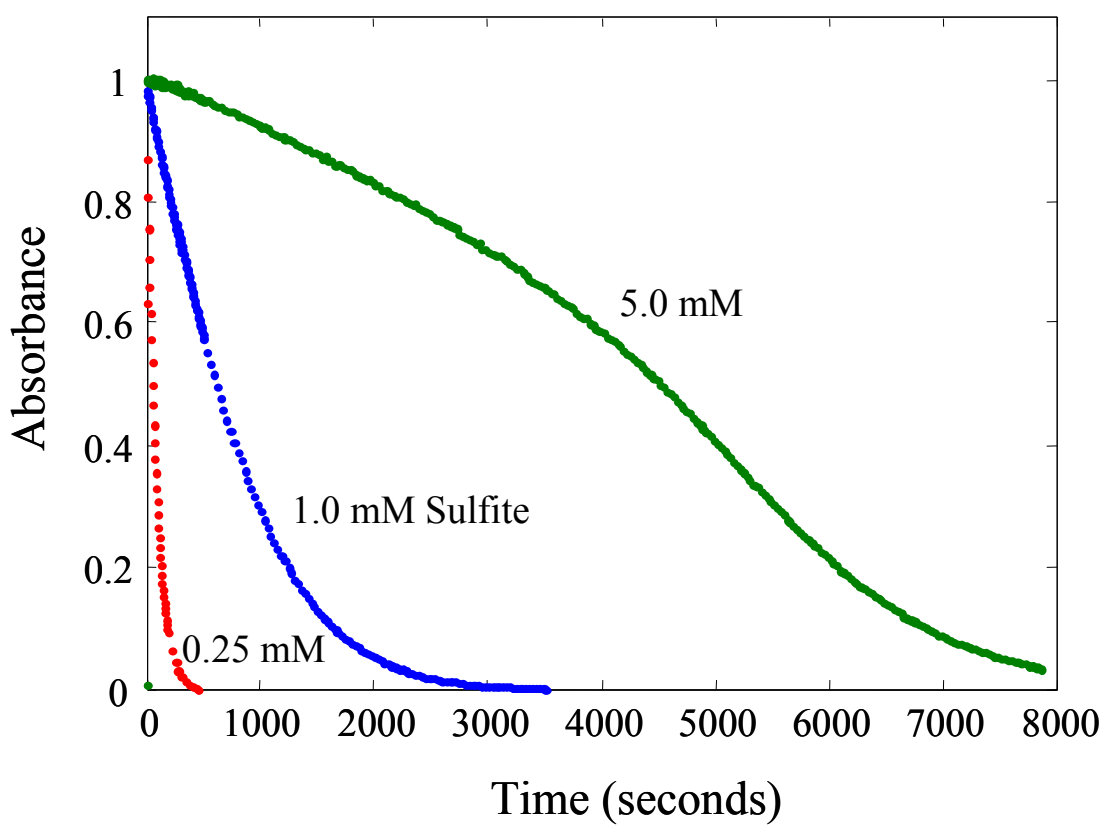

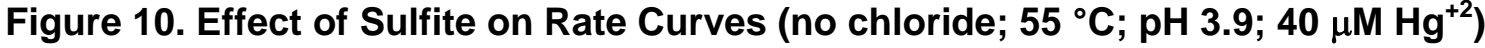


Runs have been done from $45^{\circ} \mathrm{C}$ to $55^{\circ} \mathrm{C}$ at $\mathrm{pH} 3.0$, in the absence of chloride, with initially 1.0 $\mathrm{mM}$ sulfite and $40 \mu \mathrm{M} \mathrm{Hg}^{+2}$. The results for an Arrhenius plot using $\mathrm{k}_{\text {obs }}$ is shown in Figure 11. The results are somewhat scattered, possibly due to using the "ideal" $\mathrm{k}_{\mathrm{obs}}$ approximation. However, the slope of the curve gives an activation energy of $39.2 \mathrm{kcal} / \mathrm{gmole}$, close to the literature value of $39.7 \mathrm{kcal} / \mathrm{gmole} .^{2}$ This is a high activation energy which tends to make the reduction of $\mathrm{Hg}^{+2}$ by sulfite quite sensitive to temperature.

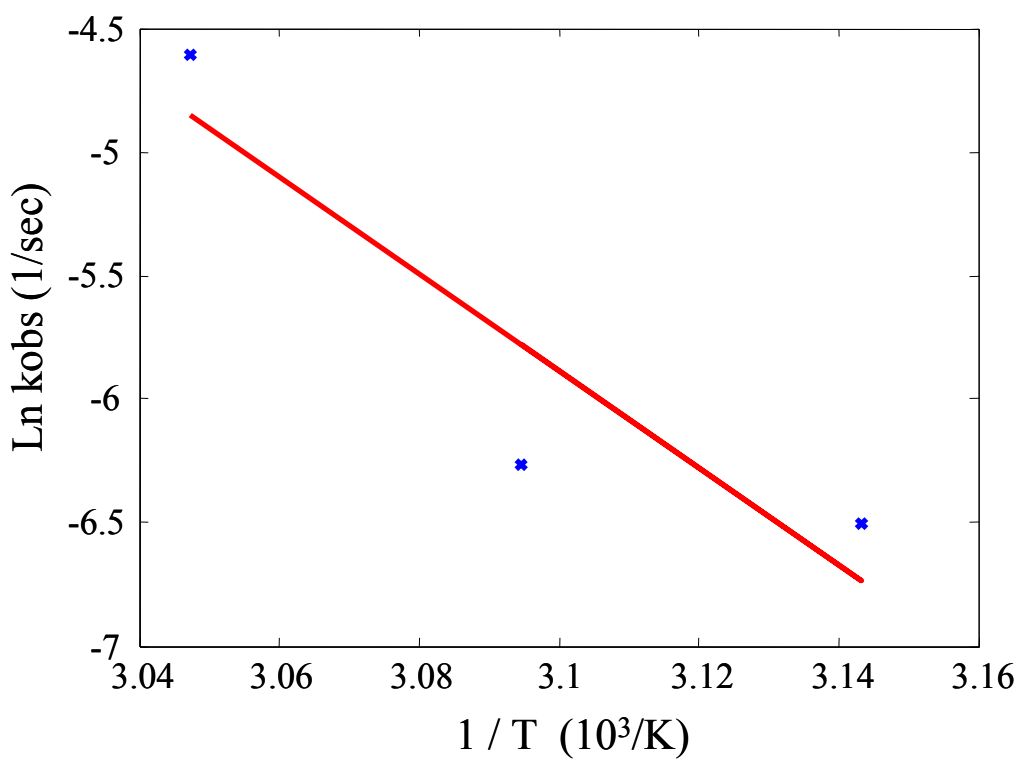

Figure 11. Effect of Temperature on $\mathrm{k}_{\mathrm{obs}}$ (no chloride, $\mathrm{pH} 3.0,1.0 \mathrm{mM}$ sulfite, $40 \mu \mathrm{M} \mathrm{Hg}^{+2}$ ) Kinetics Results for Solutions with Chloride and Other Complexing Agents

While the data shown above provide insight about aqueous reactions between $\mathrm{Hg}^{+2}$ and sulfite in a simple aqueous matrix, wet FGD systems have a number of other anions and cations that may affect these kinetics. In particular, chloride is present in all FGD liquors, and is known to form aqueous complexes with mercury.

Drastically different results are obtained when even low concentrations of chloride are added to the reaction liquor. Figure 12 shows the effects of starting the reaction with $10 \mathrm{mM}$ chloride (approximately $350 \mathrm{ppm}$ ). The lower initial absorbance indicates that the apparent initial concentration of $\mathrm{Hg}\left(\mathrm{SO}_{3}\right)_{2}{ }^{-2}$ is lower when chloride is present, but the major difference is on the rate of disappearance of the complex. The value of $\mathrm{k}_{\text {obs }}$ for the run without chloride is 40 times that of the run with chloride.

The drastic change in rate can also be observed with a different order of reagent mixing. Figure 13 shows a run that was started without any chloride present. Chloride was injected about 70 seconds into the run, resulting in the sharp drop in absorbance noted in the figure, and the change to the much slower disappearance noted at later times. The run was continued for over 7500 seconds. The $\mathrm{k}_{\mathrm{obs}}$ calculated from data obtained after chloride injection was within $25 \%$ of the value found when the run was done with chloride initially present, which is reasonable agreement. 


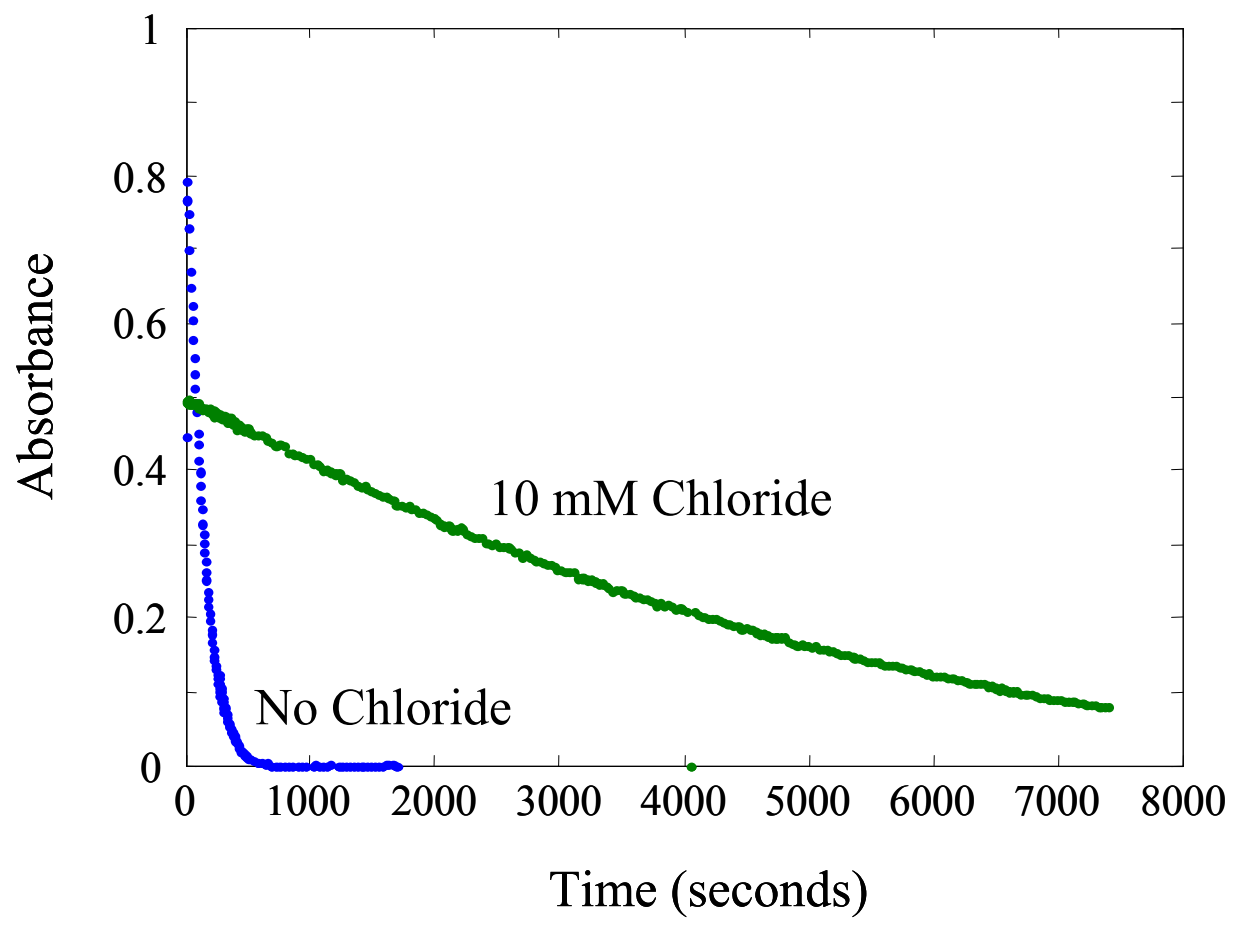

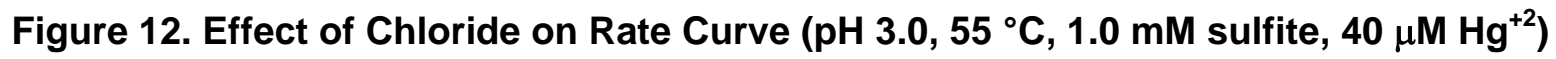

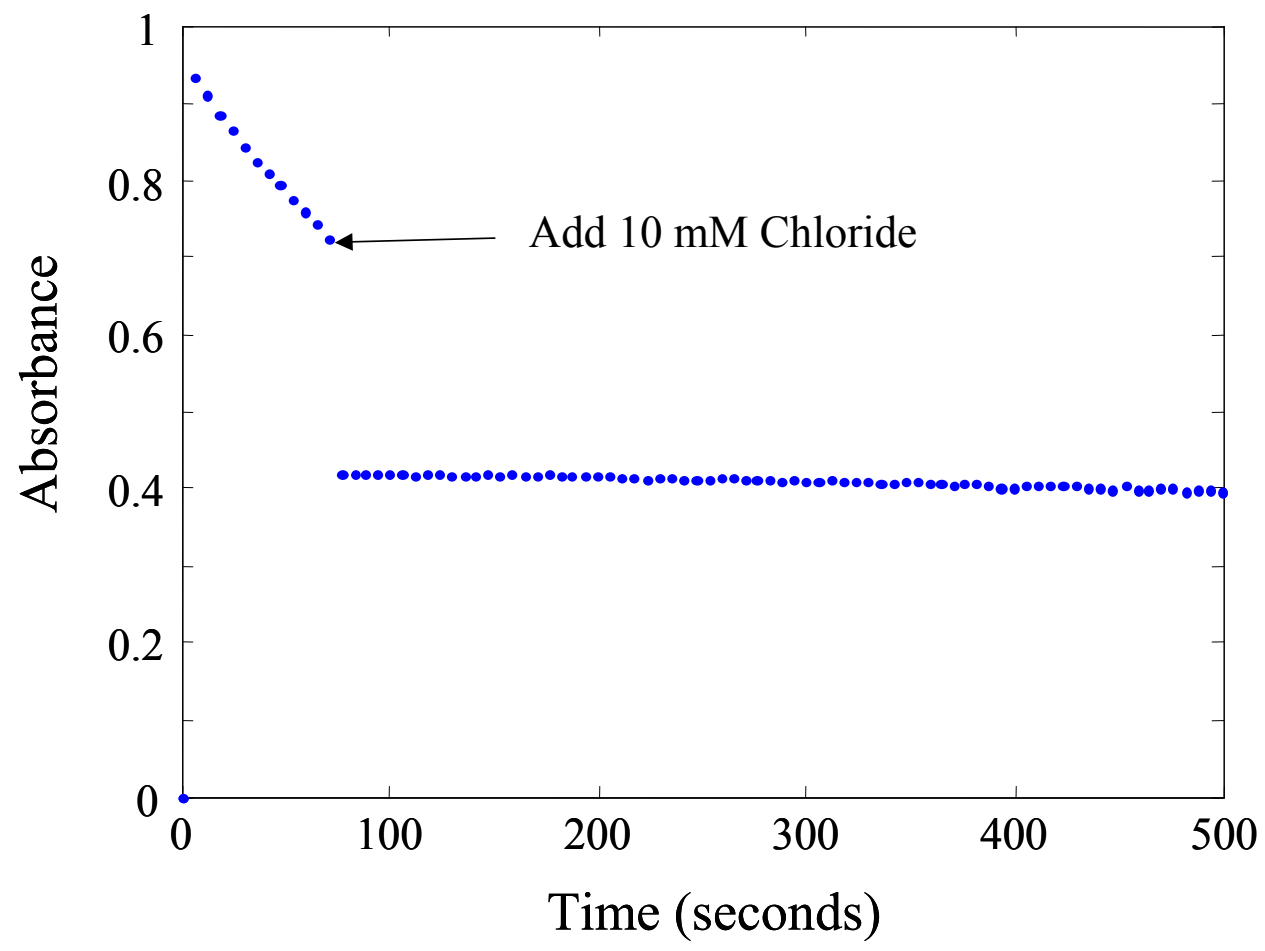

Figure 13. Effect of Adding Chloride After Start of Run (1.0 mM sulfite, $55^{\circ} \mathrm{C}, 40 \mu \mathrm{M} \mathrm{Hg}^{+2}$, $\mathrm{pH}$ 3.0)

Chloride also has a substantial effect on the $\mathrm{pH}$ dependence of the reaction. As shown in Figure 14 , the initial absorbances change with $\mathrm{pH}$ when chloride is present, but the slopes of the curves are much closer to being the same with chloride. This is quantified by a $\log -\log$ plot of $\mathrm{k}_{\mathrm{obs}}$ and 
sulfite concentration, which has a slope of only -0.21 for the $10 \mathrm{mM}$ chloride case. This is shown in Figure 15.

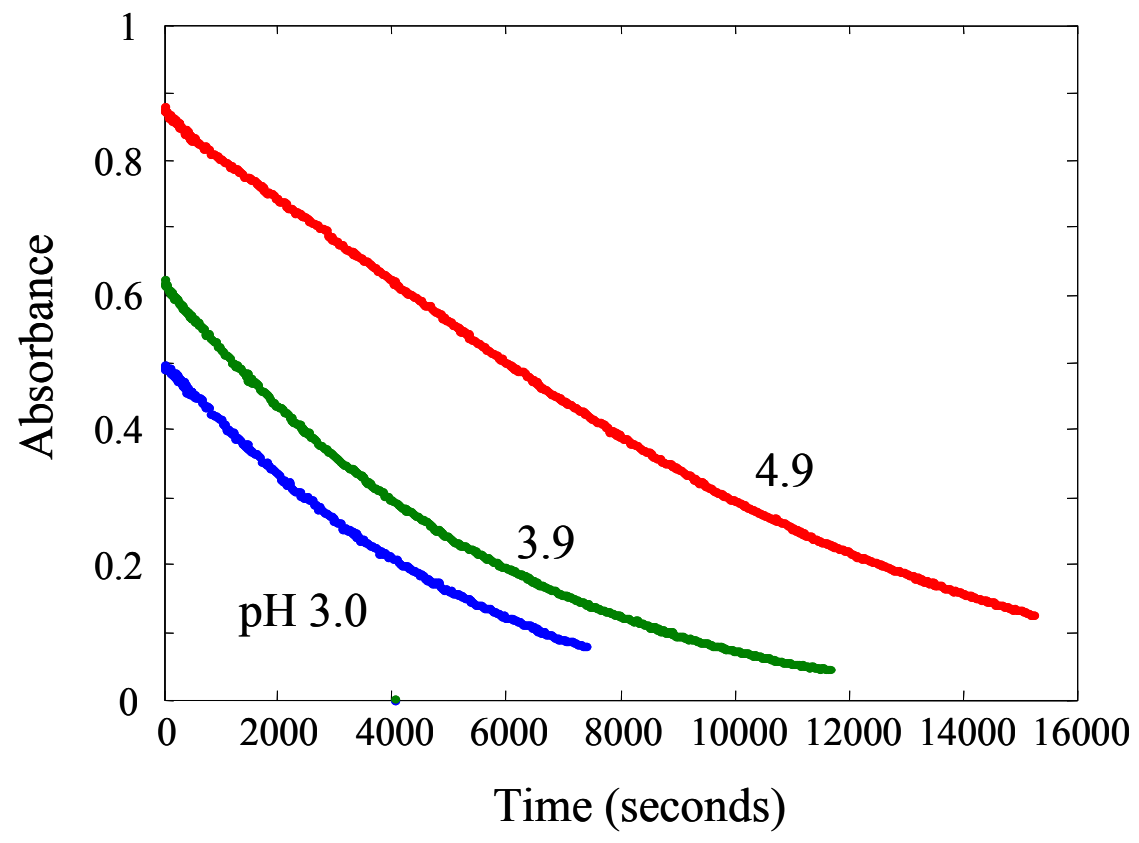

Figure 14. Effect of $10 \mathrm{mM}$ Chloride at Different $\mathrm{pH}$ Values $\left(55^{\circ} \mathrm{C}, 1.0 \mathrm{mM}\right.$ sulfite, $40 \mu \mathrm{M}$ $\mathrm{Hg}^{+2}$ )

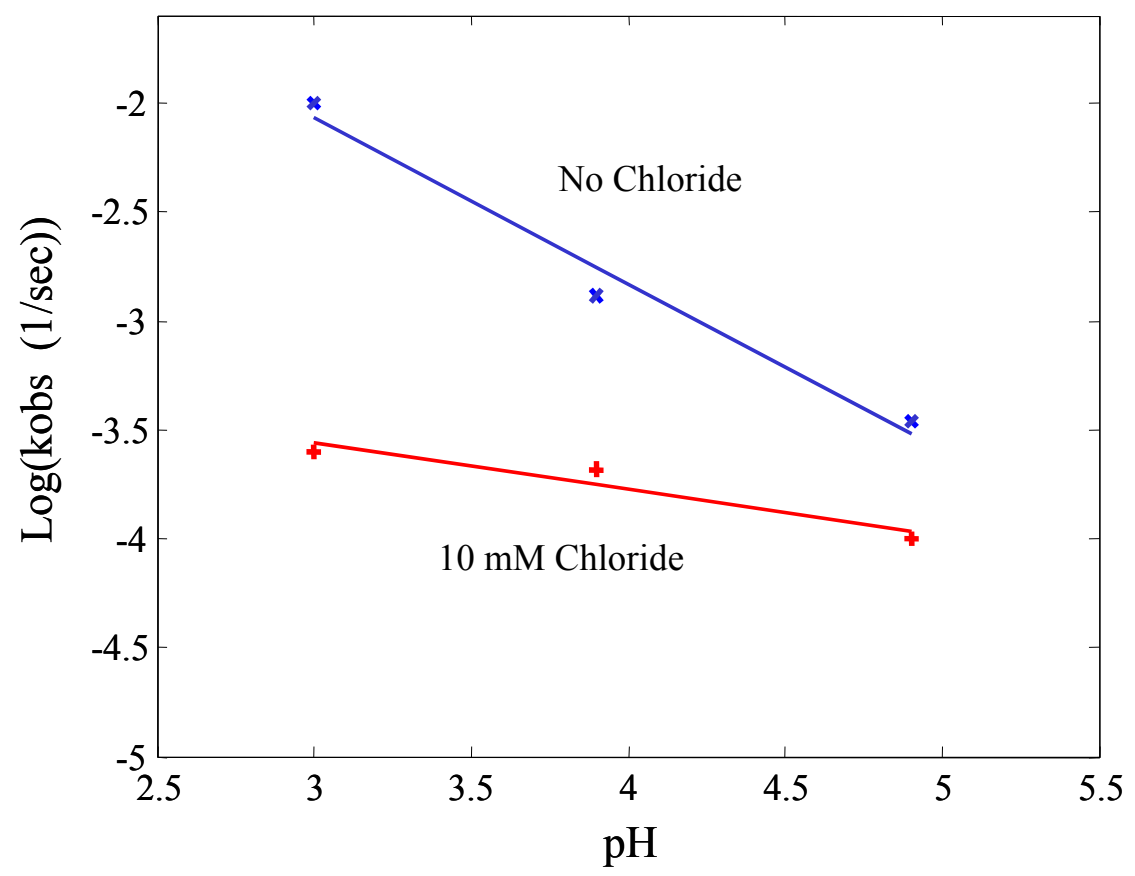

Figure 15. $\mathrm{pH}$ Dependence of $\mathrm{k}_{\mathrm{obs}}$ with and without $0.01 \mathrm{M}$ Chloride $\left(55^{\circ} \mathrm{C}, 1.0 \mathrm{mM}\right.$ sulfite, $40 \mu \mathrm{M} \mathrm{Hg}^{+2}$ )

An early version of the kinetics model predicted a slowing of the $\mathrm{Hg}^{+2}$ reduction rate when chloride is added, but did not predict the $\mathrm{pH}$ dependence. This indicated a change in mechanism 
that was not taken into account in the model. As discussed later in this section, this apparently involved the formation of a mixed complex of $\mathrm{Hg}^{+2}$ containing both chloride and sulfite. The early form of the model used complexes containing chloride and sulfite separately, but not combined.

Another possibility considered was that the reaction starts to go through mercurous intermediates instead of being the "concerted" (effectively two-electron-transfer) process proposed in the literature. Electron transfer reactions of mercurous/mercuric species were added to the model to aid in investigating this possibility, but this mechanism does not appear to be occurring to any significant extent.

As mentioned above, Figure 12 showed a smaller initial absorbance jump (originally believed to be due solely to the formation of mercuric disulfite $\left[\mathrm{Hg}\left(\mathrm{SO}_{3}\right)_{2}{ }^{-2}\right]$ ) when sulfite was added to a solution containing chloride ion, compared to the results for a solution with no chloride present. Figure 12 also showed a major slowing of the rate of decomposition of the mercuric disulfite complex ( $\mathrm{k}_{\mathrm{obs}}$ decreasing by a factor of 25 with chloride present) as indicated by the much lower rate of decay of that absorbance.

Taking this into consideration, the results shown in Figure 13 have substantial diagnostic importance. The run was started with mercuric ion and sulfite ion, but no chloride present; chloride was injected about 70 seconds after the start. When the chloride was injected there was an immediate sharp drop in absorbance, and then a change to the much slower decay of absorbance seen in runs where chloride was present from the beginning. Further examination of the complete spectra from this previous run showed that there was a small but definite shift of about 4-5 $\mathrm{nm}$ in the spectral peak wavelength when the chloride was added, as shown in Figure 16 below.

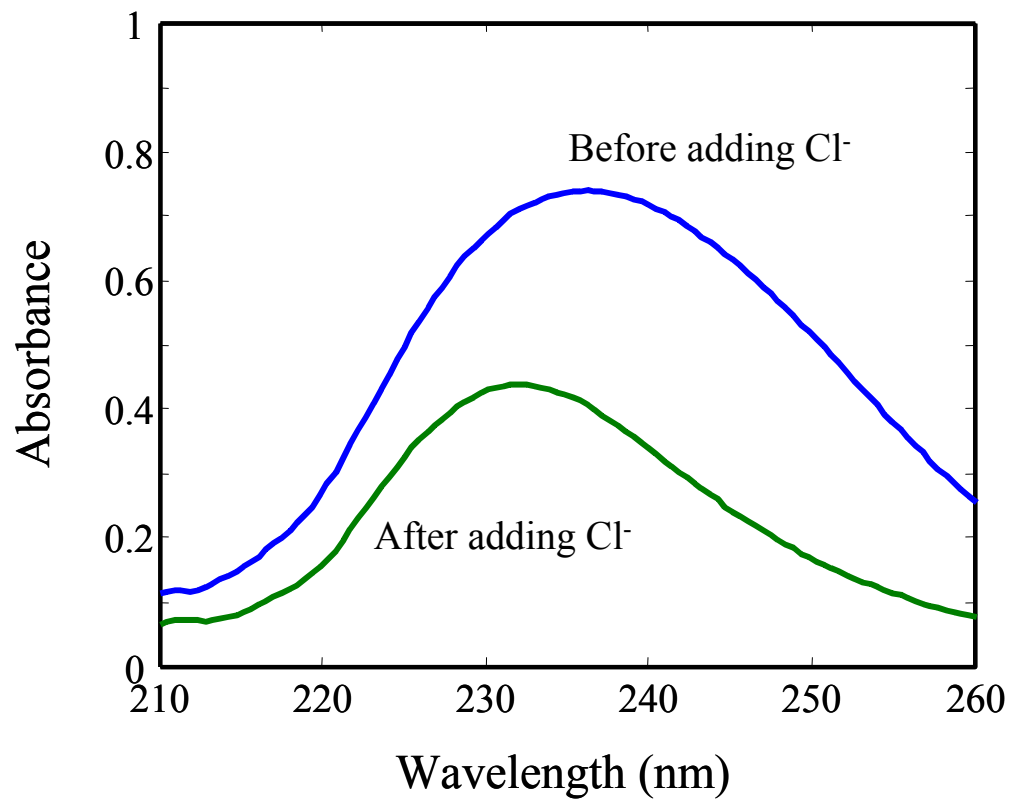

Figure 16. Shift in UV Spectra on Adding $10 \mathrm{mM}$ Chloride to $\mathrm{pH} 3.0,1.0 \mathrm{mM}$ Sulfite, $40 \mu \mathrm{M}$ $\mathrm{Hg}^{+2}$ Solution at $55^{\circ} \mathrm{C}$ 
This shift was essentially completed during the 5 seconds that elapsed between spectrum acquisition. This same difference in spectral peak wavelength was subsequently noted in the individual runs done with and without chloride addition. The peak values occur at approximately $232 \mathrm{~nm}$ with chloride and $237 \mathrm{~nm}$ without chloride. This behavior suggested the formation of a different complex than the $\mathrm{Hg}\left(\mathrm{SO}_{3}\right)_{2}^{-2}$ complex that is formed in the absence of chloride.

Inspection of analytical chemistry literature showed that mixed chloride-sulfite mercuric complexes have been suspected in analytical methods for $\mathrm{SO}_{2}$ that use tetrachloromercurate as an absorbent. Dasgupta and DeCesare assigned a spectral peak similar to the one we observed to the complex $\mathrm{ClHgSO}_{3}{ }^{-}$, but did not investigate it in detail. ${ }^{3}$ During the current project sulfite was "titrated" into a solution of mercuric ion with a low concentration of chloride present. This was done at a low temperature of $10{ }^{\circ} \mathrm{C}$ to minimize mercury reduction. As shown in Figure 17, the absorbance increases rapidly as sulfite is added up to about $0.04 \mathrm{mM}$ sulfite, which is equal to the original concentration of mercuric ion, then changes much more slowly with further increases in sulfite concentration.

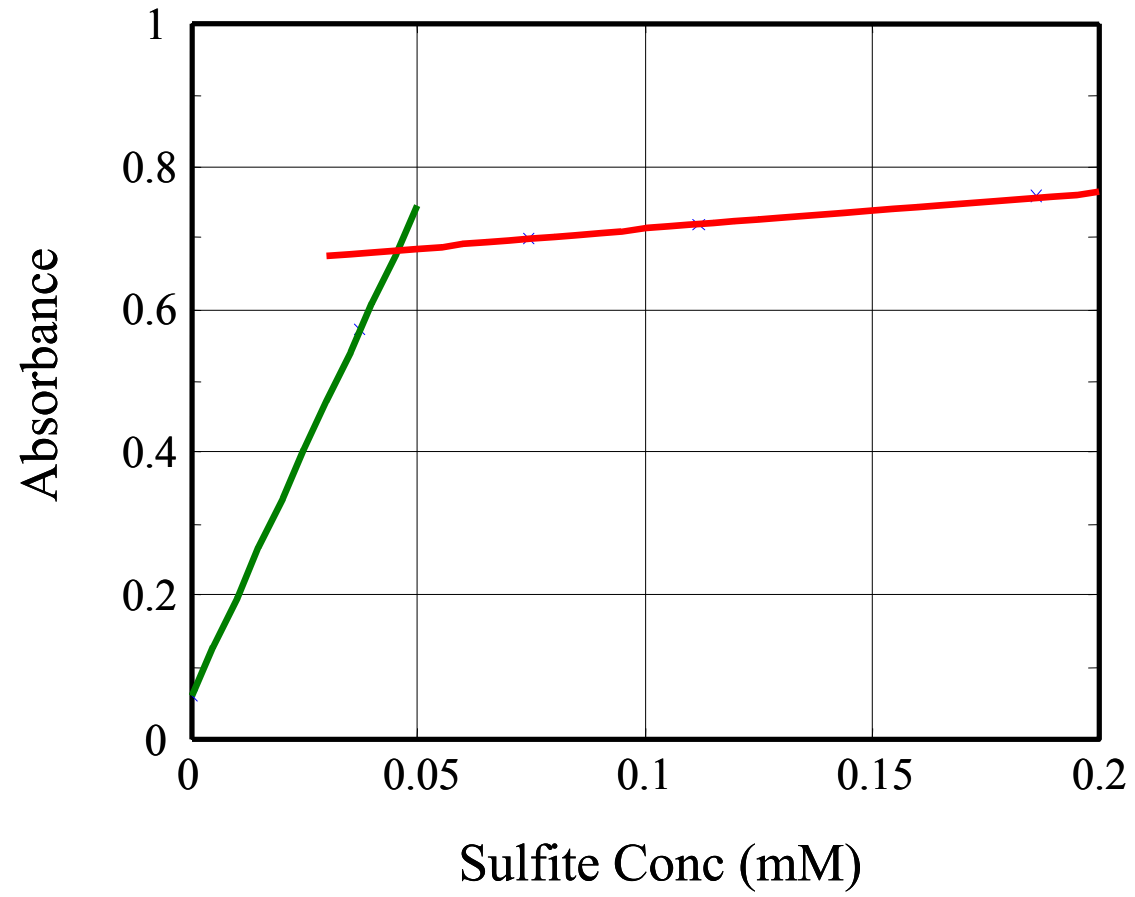

Figure 17. Absorbance at $232 \mathrm{~nm}$ During Addition of Sulfite to a Solution Containing 1.0 $\mathrm{mM}(\sim 35 \mathrm{ppm}) \mathrm{Cl}, 40 \mu \mathrm{M} \mathrm{Hg}^{+2}$ at $\mathrm{pH} 3.5$ and $10^{\circ} \mathrm{C}$

This is consistent with the formation of a 1:1 complex between a chlorinated $\mathrm{Hg}^{+2}$ species and $\mathrm{SO}_{3}^{-2}$, rather than the 2:1 complex between $\mathrm{Hg}^{+2}$ and $\mathrm{SO}_{3}{ }^{-2}$ to form mercuric disulfite. We have obtained good modeling simulations of the basic rate phenomena in low chloride solutions by adding the following reactions to the model.

$\mathrm{HgCl}^{+}+\mathrm{SO}_{3}^{-2} \leftrightarrow \mathrm{ClHgSO}_{3}^{-}$

$\mathrm{ClHgSO}_{3}^{-}+\mathrm{H}_{2} \mathrm{O} \rightarrow \mathrm{Hg}^{0}+\mathrm{HSO}_{4}^{-}+\mathrm{Cl}^{-}+\mathrm{H}^{+}$ 
The chloride ion attached to the mercury apparently slows the decomposition of the complex by a very substantial amount. The monosulfite complex, $\mathrm{HgSO}_{3}$, is thought to decompose much faster than the disulfite complex, $\mathrm{Hg}\left(\mathrm{SO}_{3}\right)_{2}{ }^{-2}$. It now appears that the disulfite complex in turn decomposes or disassociates to $\mathrm{HgSO}_{3}$ much more rapidly than the complex containing chloride.

At higher chloride concentrations the results become increasingly complicated. Typical spectrophotometric results obtained at 10,30 , and $100 \mathrm{mM}$ chloride concentrations, and taken at wavelengths of 231, 232, and $232 \mathrm{~nm}$, respectively, are shown in Figure 18. These chloride millimolar concentrations correspond with approximately $350,1,060$, and 3,550 ppm, respectively Results obtained at 250 and $1000 \mathrm{mM}$ chloride (approximately 8,860 and 35,500 ppm, respectively) taken at 230 and $231 \mathrm{~nm}$ are shown in Figure 19 along with the $10 \mathrm{mM}$ results from Figure 18 for comparison. All of these runs were initiated by injection of sulfite to a cuvette containing chloride and mercuric ions at $" \mathrm{t}=0$." Spectra were taken at 5 second or 10 second intervals. The absorbances in these two figures were taken from the average peak wavelength values during the run. The peak wavelengths varied somewhat during the runs but were generally from $230-235 \mathrm{~nm}$.

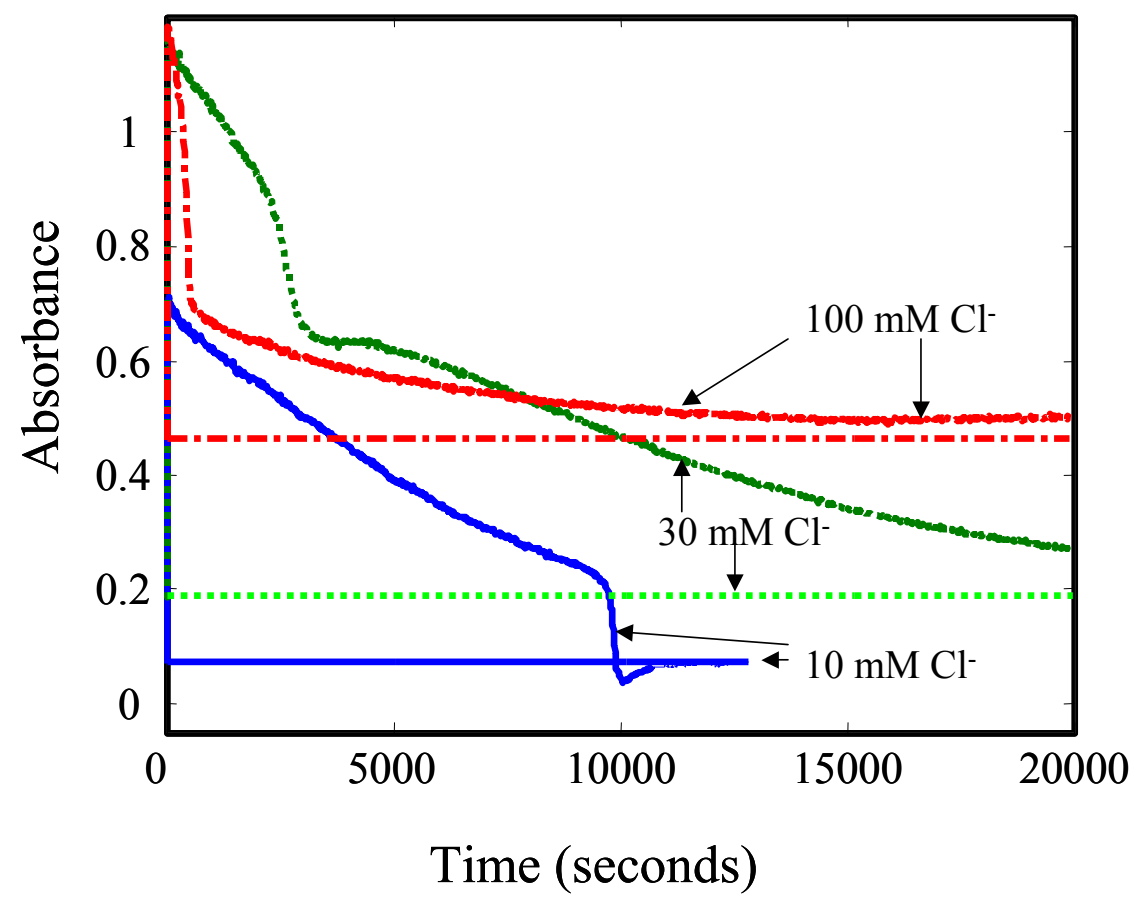

Figure 18. Rate Curves for Addition of $1.0 \mathrm{mM}$ Sulfite to Solutions Containing $10 \mathrm{mM}, 30$ $\mathrm{mM}$, and $100 \mathrm{mM}$ Chloride $\left(55^{\circ} \mathrm{C}, \mathrm{pH}\right.$ 3-3.5, 40 microM $\mathrm{Hg}^{+2}$ ) 


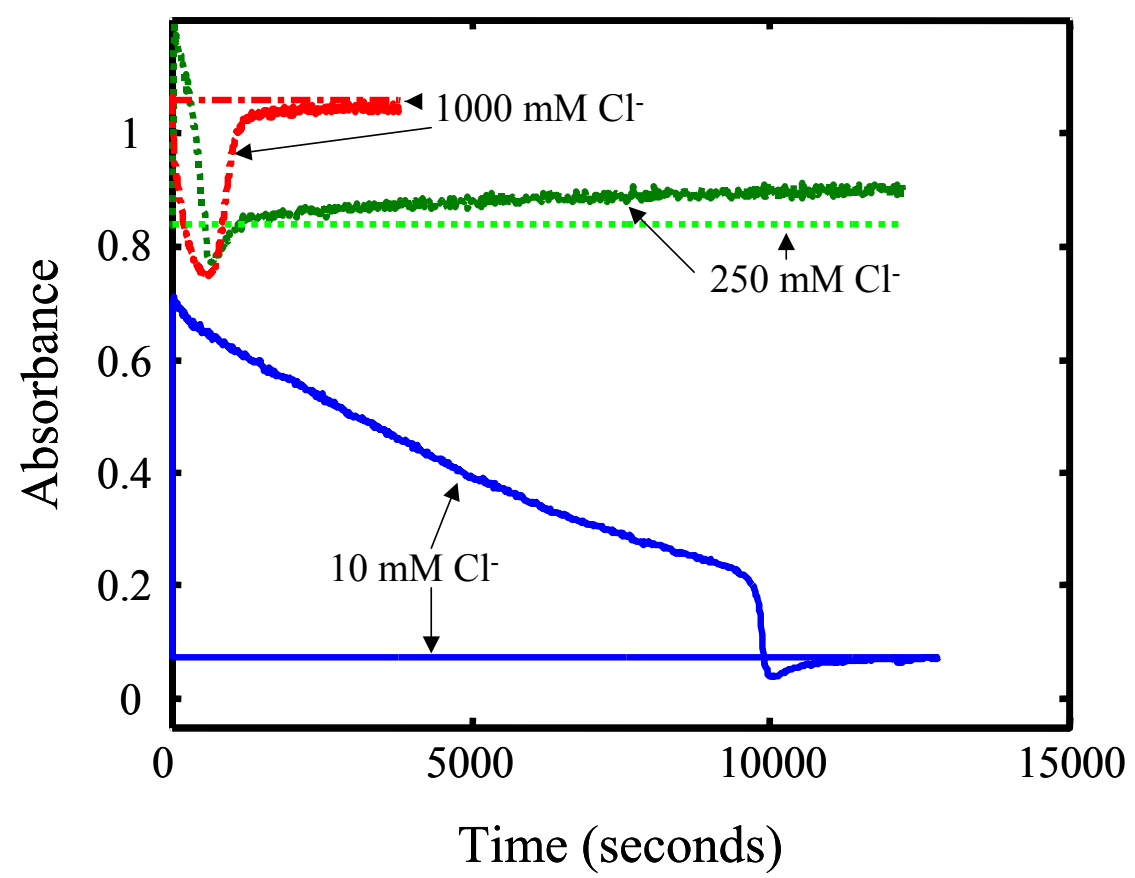

Figure 19. Rate Curves for Addition of $1.0 \mathrm{mM}$ Sulfite to Solutions Containing $10 \mathrm{mM}, 250$ $\mathrm{mM}$, and $1000 \mathrm{mM}$ Chloride $\left(55^{\circ} \mathrm{C}, \mathrm{pH} 3-3.5,40\right.$ microM $\mathrm{Hg}^{+2}$ )

The runs represented in these two figures were done at $55^{\circ} \mathrm{C}$ with $40 \mu \mathrm{M} \mathrm{Hg}^{+2}$ and $1.0 \mathrm{mM}$ sulfite added at time zero. No $\mathrm{pH}$ buffer was used and the $\mathrm{pH}$ for individual runs varied from 33.5 , but the variation from start to end of any given run was usually less than $0.2 \mathrm{pH}$ units. The initial baseline absorbances with chloride added are shown as horizontal lines in both figures. At the lowest chloride concentration, the baseline absorbance by mercuric chloride complexes is fairly small, but it becomes quite large at higher chloride concentration. This effect is nonlinear because the monochloro- and dichloromercuric complexes have fairly low molar light absorptivities, while the trichloro- and tetrachloromercuric complexes have high molar light absorptivities. In $10 \mathrm{mM}$ chloride the primary mercury species is the dichloromercuric complex, $\mathrm{HgCl}_{2}$; in $1000 \mathrm{mM}$ chloride the tetrachloromercuric complex, $\mathrm{HgCl}_{4}{ }^{-2}$ predominates. The tetrachloromercuric complex has an absorptivity slightly higher than the disulfitomercuric complex $\left(\mathrm{Hg}\left(\mathrm{SO}_{3}\right)_{2}{ }^{-2}\right)$ and it peaks at nearly the same wavelength, $231 \mathrm{~nm}$.

In Figure 18, the $10 \mathrm{mM}$ results are explainable by the formation and decay of the $\mathrm{ClHgSO}_{3}{ }^{-}$ complex as described above, up to the point of the fast drop in absorbance seen at about 10,000 seconds. This drop actually goes below the initial absorbance baseline due to chloromercuric complexes but then returns to near that baseline at longer times. The fact that the absorbance returns to baseline levels might call into question whether any net reduction of $\mathrm{Hg}^{+2}$ occurred. However, later stripping experiments carried out under similar conditions definitely show formation and release of elemental mercury, as will be described below.

The $30 \mathrm{mM}$ chloride run shows an initial increase in absorbance that is larger than can be explained by formation of $\mathrm{ClHgSO}_{3}{ }^{-}$. This is followed by a steady decay then a "drop," a short plateau, and a slow steady decay that had not reached the initial baseline after 20,000 seconds. 
The $100 \mathrm{mM}$ chloride case shows a smaller initial increase on sulfite addition than does the 30 $\mathrm{mM}$ case, but a much more rapid initial drop followed by a very slow decay which was still approaching the initial baseline after 20,000 seconds. The $250 \mathrm{mM}$ case shows a yet smaller initial increase when sulfite is added but a rapid drop similar to the $100 \mathrm{mM}$ case, although it goes below the initial baseline then slowly increases to somewhat above it.

The $1000 \mathrm{mM}$ chloride case does not show any increase in absorbance when sulfite is added. Instead, the absorbance decreases to a minimum then increases back to near the initial baseline value. Figure 20, below, shows the $1000 \mathrm{mM}$ chloride results at shorter times along with the growth and decay of a "shoulder" peak at $253 \mathrm{~nm}$. The increase and decay of the absorbance at $253 \mathrm{~nm}$ appears to be roughly correlated with the opposite changes occurring in the $231 \mathrm{~nm}$ spectral region and could thus be due to a reaction intermediate.

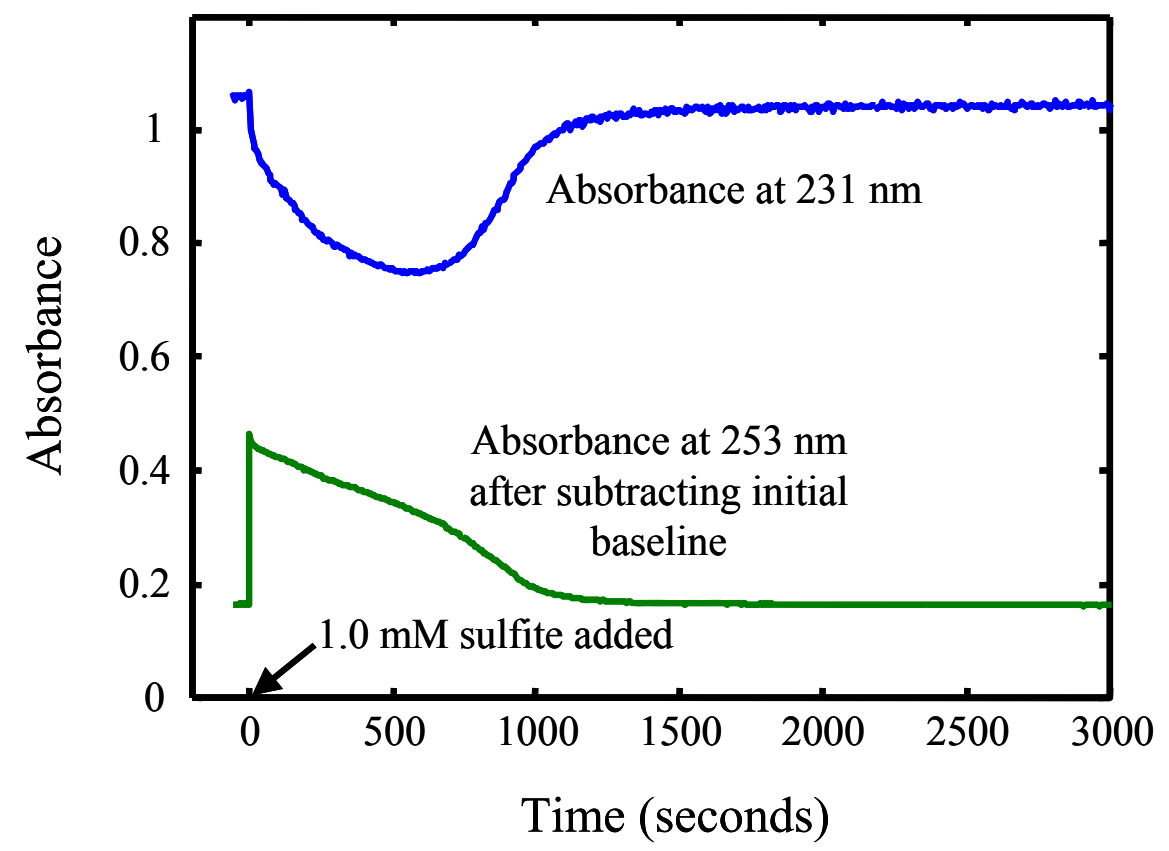

Figure 20. Rate Curves at Two Wavelengths on Addition of $1.0 \mathrm{mM}$ Sulfite to Solution Containing $1000 \mathrm{mM}$ Chloride $\left(55^{\circ} \mathrm{C}, \mathrm{pH} 3.5,40\right.$ microM $\left.\mathrm{Hg}^{+2}\right)$

As mentioned above, this return to the baseline absorbance suggests the possibility that mercuric species are not being reduced to form elemental mercury. As a check on the difficulty of reducing mercuric species at high chloride concentration, we looked at the reduction of mercuric species in $1000 \mathrm{mM}$ chloride using a chip of magnesium metal as the reductant instead of sulfite. There is a small rise in absorbance due to blocking of light by the chip. But aside from this, the results in Figure 21 show a smooth and fairly rapid decrease in total absorbance due to the chloromercuric species, as would be expected from reduction of these species. Thus, there does not appear to be an inherent barrier to reduction of $\mathrm{Hg}^{+2}$ at high chloride concentrations. 


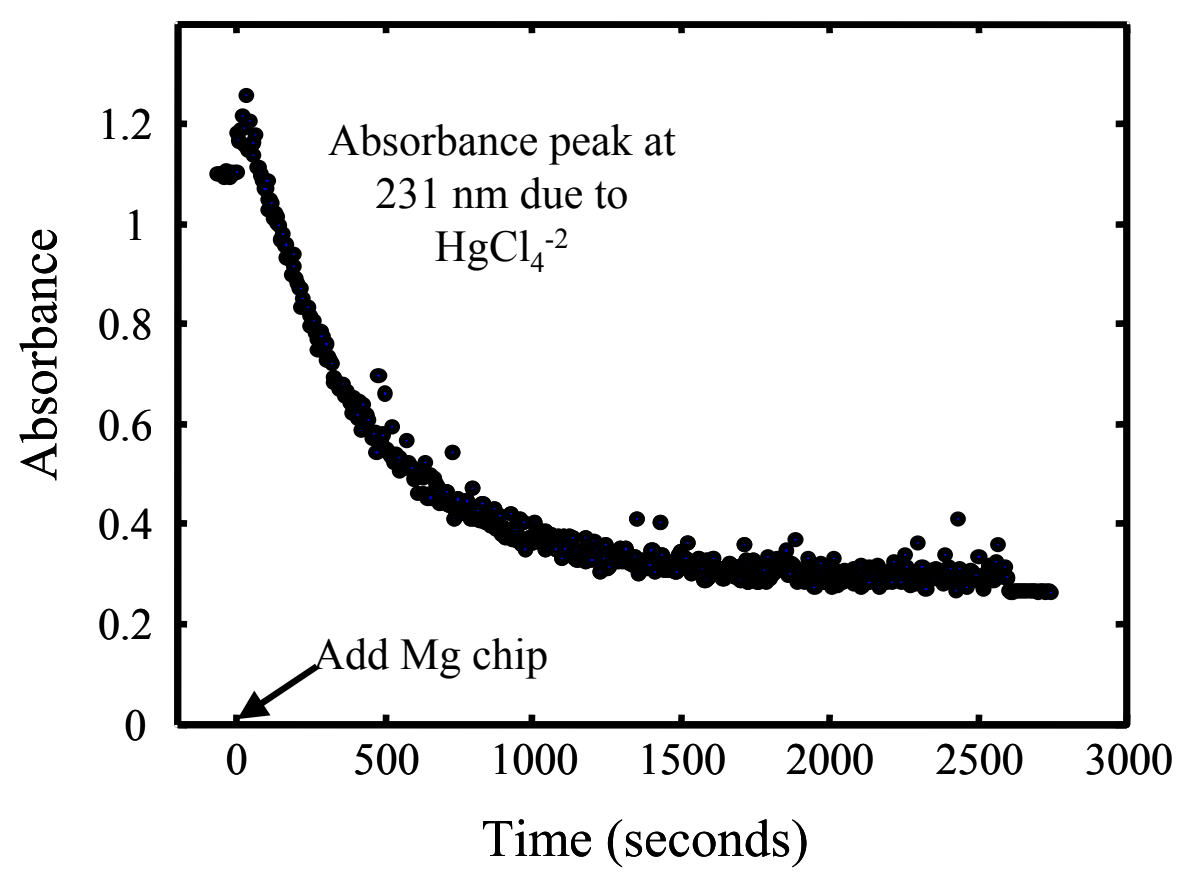

Figure 21. Effect of Adding a Magnesium Chip to a Solution Containing $1.0 \mathrm{M} \mathrm{NaCl}$ and 40 microM $\mathrm{Hg}^{+2}$ at $55^{\circ} \mathrm{C}$

A number of tests were conducted to try to unravel the possible interplay between kinetics and equilibria of formation of multiple complexes of $\mathrm{Hg}^{+2}$ with $\mathrm{Cl}^{-}$and $\mathrm{SO}_{3}{ }^{-2}$. For example, the formation of another mercury complex containing both chloride and sulfite, along with its decomposition reaction, was added to the kinetics model as shown below:

$\mathrm{HgCl}_{2}+\mathrm{SO}_{3}^{-2} \leftrightarrow \mathrm{Cl}_{2} \mathrm{HgSO}_{3}^{-2}$

$\mathrm{Cl}_{2} \mathrm{HgSO}_{3}^{-2}+\mathrm{H}_{2} \mathrm{O} \rightarrow \mathrm{Hg}^{0}+\mathrm{HSO}_{4}^{-}+2 \mathrm{Cl}^{-}+\mathrm{H}^{+}$

Modeling and lab measurements to determine the formation constants of the complexes indicate that this helps fit the observed data to a kinetics model, although the formation of the dichloro complex is less favored than the formation of the monochloro complex. At high chloride concentrations the chloromercuric complexes alone tend to dominate over the formation of mercuric sulfite and mercuric disulfite, and "shut down" the other reactions. However, it is difficult to interpret and determine all of the necessary information based on spectrophotometric results alone. As described later in this section, $\mathrm{Hg}^{0}$ stripping rate measurements were conducted to verify and extend the spectrophotometric results.

\section{Reaction Mechanism Experiments}

A number of experiments were performed to gather information on possible re-emission reaction pathways and mechanisms. This included measuring ionic strength effects, looking for various intermediates, adding $\mathrm{O}_{2}$ to the system, and investigating possible measurement artifacts involving photochemical effects and buffer stability. 
Ionic strength is related to the total concentration of dissolved ionic species in the liquid. Determining ionic strength effects is often helpful for determining reaction mechanisms for model development. The rate of reaction in a solution can be increased, decreased, or unchanged with increasing ionic strength, depending on whether the reactants in a rate-determining reaction step have the same charge, an opposite charge, or if one reactant is uncharged. We looked at the effects of ionic strength by measuring rate constants for the disappearance of mercuric disulfite from solution as a function of added electrolyte concentration, using an "inert," non-complexing electrolyte, sodium perchlorate $\left(\mathrm{NaClO}_{4}\right)$. Results obtained at $\mathrm{pH} 3.0,55^{\circ} \mathrm{C}, 1.0 \mathrm{mM}$ sulfite, 40 $\mu \mathrm{M} \mathrm{Hg}^{+2}$ in the absence of chloride are shown in Figure 22.

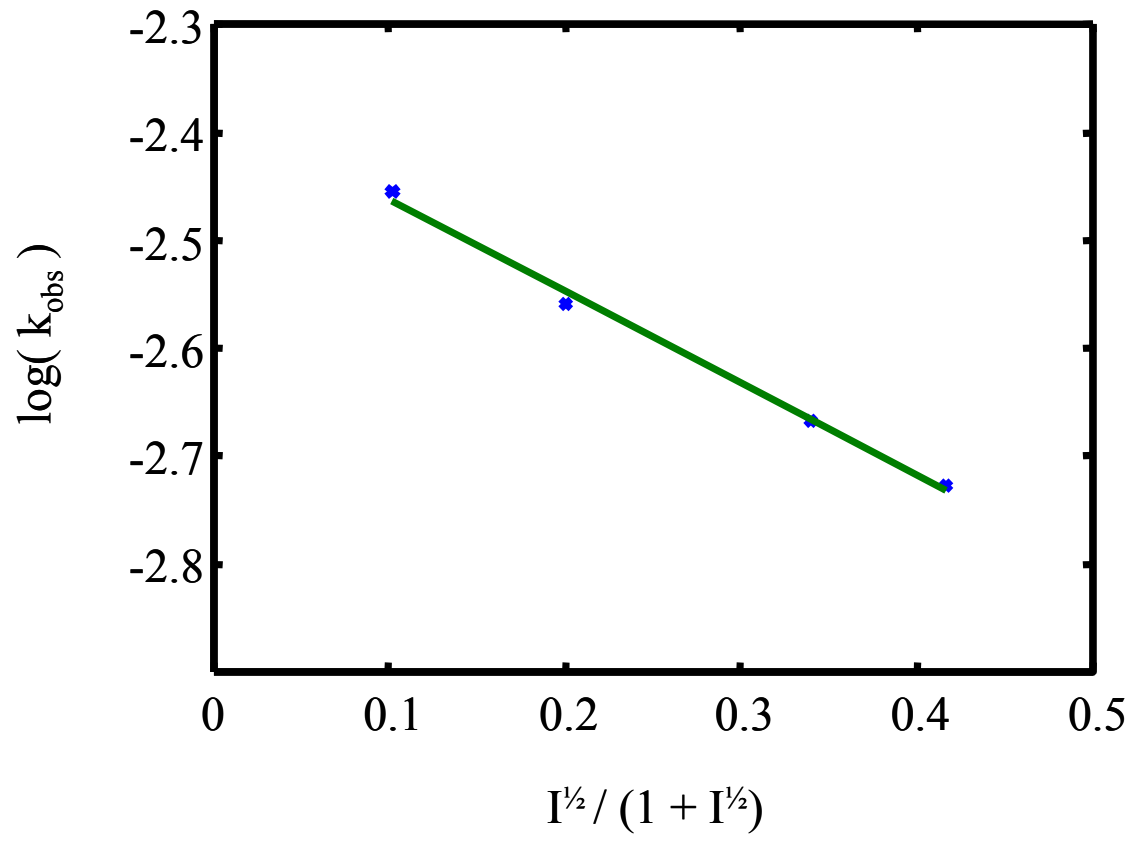

Figure 22. Ionic Strength Dependence of $\mathrm{k}_{\mathrm{obs}}\left(55^{\circ} \mathrm{C}, 1.0 \mathrm{mM}\right.$ sulfite, $\mathrm{pH}$ 3.0, 40 microM $\mathrm{Hg}^{+2}$ )

This shows that the rate decreases with increasing salt concentration. The plotted form uses the Debye-Huckel-Bronsted relation for the "primary salt effect," where $\mathrm{k}$ is the observed rate constant, $\mathrm{k}_{\mathrm{o}}$ is the rate constant at zero ion strength, $\mathrm{I}$ is the ionic strength defined in terms of the charges on the ions $\left(\mathrm{z}_{\mathrm{i}}\right)$ and molar concentrations of the ions $\left(\mathrm{M}_{\mathrm{i}}\right)$, and $\mathrm{A}_{\gamma}$ is a temperaturedependent constant $=0.5371$ at $55^{\circ} \mathrm{C}$.

$\log \mathrm{k}=\log \mathrm{k}_{\mathrm{o}}+2 \mathrm{~A}_{\gamma} \mathrm{z}_{\mathrm{A}} \mathrm{Z}_{\mathrm{B}} \mathrm{I}^{1 / 2} /\left(1+\mathrm{I}^{1 / 2}\right) \quad$ where: $\mathrm{I}=1 / 2 \Sigma \mathrm{z}_{\mathrm{i}}^{2} \mathrm{M}_{\mathrm{i}}$

A value of $z_{A} z_{B}=-0.79$ was obtained from the slope of the curve. A value of -1 indicates that two species, one with a +1 charge and the other with a -1 charge, are involved in a ratedetermining step, and that is probably the case for the experimental result. The value obtained in the presence of $10 \mathrm{mM}$ chloride is slightly lower, -0.69 . The most likely reactant having a charge of +1 is hydrogen ion. For the case with chloride, a candidate for the -1 charged ion is $\mathrm{ClHgSO}_{3}$, and a possible rate-determining reaction is: 
$\mathrm{ClHgSO}_{3}^{-}+\mathrm{H}^{+}+\mathrm{H}_{2} \mathrm{O} \rightarrow \mathrm{Hg}^{0}+\mathrm{HSO}_{4}^{-}+\mathrm{Cl}^{-}+2 \mathrm{H}^{+}$

Since hydrogen ion is not consumed in the overall reaction, this would constitute hydrogen ion catalysis.

However, the data shown in Figure 22 are without chloride in the solution. It is more difficult to identify a candidate -1 charged species for the case without chloride, since the two reactive complexes are usually assumed to be $\mathrm{HgSO}_{3}$ and $\mathrm{Hg}\left(\mathrm{SO}_{3}\right)_{2}{ }^{-2}$. However it is quite possible that the disulfite complex is protonated, giving the singly charged species $\left(\mathrm{HSO}_{3}\right) \mathrm{Hg}\left(\mathrm{SO}_{3}\right)^{-}$which reacts with $\mathrm{H}^{+}$and water similarly to the chloromercuric sulfite.

$\left(\mathrm{HSO}_{3}\right) \mathrm{Hg}\left(\mathrm{SO}_{3}\right)^{-}+\mathrm{H}^{+}+\mathrm{H}_{2} \mathrm{O} \rightarrow \mathrm{Hg}^{0}+\mathrm{HSO}_{4}^{-}+\mathrm{HSO}_{3}^{-}+2 \mathrm{H}^{+}$

This reaction could have another interesting pathway involving simultaneous electron transfer, one from each of the two sulfite ligands, to the mercuric center. Although speculative, this might explain why replacing a sulfite with a chloride on the mercury center slows down the reduction.

As noted previously in this report, under "ideal" conditions at low $\mathrm{pH}$ (3), low sulfite, and no other complexing agents, the reduction of $\mathrm{Hg}^{+2}$ by sulfite produces textbook first order decay curves. However at other conditions, particularly those which slow down the reaction, the shape of the absorbance - time curve starts to deviate significantly from what one would expect from a simple first order reaction, and significant changes are often seen in the time behavior during the run. This is usually a sign that reaction intermediates are being formed that either inhibit or accelerate the overall reaction.

The overall reaction of $\mathrm{Hg}^{+2}$ with sulfite involves a two-electron change for both $\mathrm{Hg}^{+2}$, going to $\mathrm{Hg}^{0}$, and for sulfite, going to sulfate $\left(\mathrm{S}^{+4}\right.$ to $\left.\mathrm{S}^{+6}\right)$. Potential intermediates thus include those formed by one-electron steps such as mercurous $\left(\mathrm{Hg}^{+1}\right)$ species and oxysulfur radicals such as the sulfite radical anion, $\cdot \mathrm{SO}_{3}{ }^{-}$.

A spectrophotometric experiment was done starting with $40 \mu \mathrm{M}$ mercurous ion $\left(\mathrm{Hg}_{2}{ }^{+2}\right)$ instead of the usual $40 \mu \mathrm{M} \mathrm{Hg}^{+2}$, at $55^{\circ} \mathrm{C}$ and $\mathrm{pH} 3.0$, with addition of $1.0 \mathrm{mM}$ sulfite to start the run as usual. The initial mercurous perchlorate solution was prepared by stirring a de-aerated $0.01 \mathrm{M}$ $\mathrm{Hg}\left(\mathrm{ClO}_{4}\right)_{2}$ solution over a mercury pool for 48 hours and dilution. The results are shown in Figure 23. 


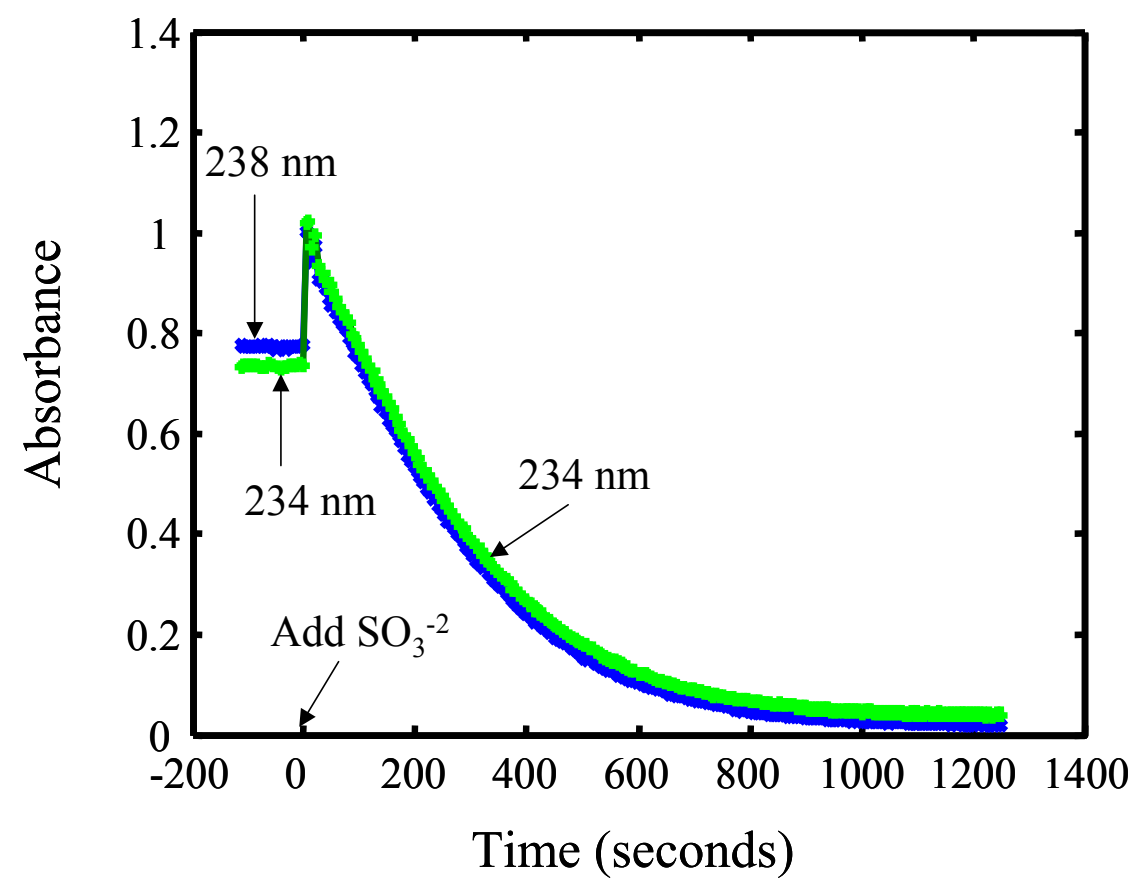

Figure 23. Rate Curve at Two Wavelengths for the Addition of Sulfite to a Solution Initially Containing Mercurous lon at $55^{\circ} \mathrm{C}$ and $\mathrm{pH} 3.0$

Mercurous ion has a significant absorption peak at $238 \mathrm{~nm}$ and this is indicated by the absorbance before addition of sulfite. Examination of the individual spectra shows a distinct change in spectra from one having a peak of $238 \mathrm{~nm}$ (i.e., the absorbance is greater at $238 \mathrm{~nm}$ than at $234 \mathrm{~nm}$ ) at an absorbance of 0.77 to one having a peak at $234 \mathrm{~nm}$ (greater absorbance than at $238 \mathrm{~nm}$ ) and absorbance of 1.00 , occurring within the 5 -second period between spectrum acquisition. The latter spectrum corresponds with $36 \mu \mathrm{M}$ of the mercuric disulfite complex. The URS kinetics model predicts a nearly identical starting concentration of $35 \mu \mathrm{M}$ when starting with $\mathrm{Hg}^{+2}$ rather than mercurous ion in solution. The ensuing decay rate is also essentially the same as would be expected for mercuric disulfite under these conditions.

These results can be explained by rapid and practically complete disproportionation of mercurous ion induced by sulfite, as shown in the following reaction.

$\mathrm{Hg}_{2}{ }^{+2}+2 \mathrm{SO}_{3}^{-2} \rightarrow \mathrm{Hg}^{0}+\mathrm{Hg}\left(\mathrm{SO}_{3}\right)_{2}^{-2}$

This would indicate that while the mercurous ion $\mathrm{Hg}_{2}{ }^{+2}$ may still be a transient intermediate, it probably does not build up to significant concentration levels. There was a persistent residual absorbance peak at $223 \mathrm{~nm}$ with absorbance of 0.20 after the main reactions were completed in this run that is not seen in runs started with $\mathrm{Hg}^{+2}$. Its origin is not known but might be associated with the $\mathrm{Hg}^{0}$ product, perhaps in colloidal form.

Sulfite radical anion is thought to be an important intermediate in FGD sulfite oxidation chemistry. Although the direct reaction of oxygen with sulfite is quite slow, it is catalyzed by transition metal ions (such as iron, manganese, and copper) whose oxidized forms can oxidize 
sulfite to the radical ion. Since sulfite is undergoing oxidation in the reactions we are studying, the sulfite radical ion $\cdot \mathrm{SO}_{3}{ }^{-}$could be formed. This species has an absorption peak at $255 \mathrm{~nm}$, but its absorptivity is low (approximately $1000 \mathrm{~L} /($ gmole $\mathrm{cm})$ ) so it would be difficult to detect in the presence of other UV absorbing species such as we have in these experimental procedures. Since involvement of $\cdot \mathrm{SO}_{3}{ }^{-}$should be indicated by sensitivity of the results to oxygen, we instituted stringent pre-purging of reaction cuvette and restriction of air access to reagents before the run, but did not see any noticeable effect. We then did a run using intentionally aerated solutions and obtained virtually the same spectrophotometric results and $\mathrm{k}_{\mathrm{obs}}$ as usual. Finally, we did $\mathrm{Hg}^{0}$ stripping kinetics runs with pure oxygen instead of nitrogen as the major gas. While the $\mathrm{k}_{\mathrm{obs}}$ values were somewhat lower (by an average of $32 \%$ ) with oxygen than without, no unusual changes in shape of the rate curves were apparent. As was the case with the mercurous ion screening, this does not rule out the transient formation of $\cdot \mathrm{SO}_{3}{ }^{-}$, but it does not appear as if this species plays a major role as judged by aeration effects.

\section{Checks for Experimental Artifacts}

Mercury compounds are known to undergo photochemical reactions. Although the light source used to make our spectrophotometric measurements is low intensity, we checked to see if it could be causing photochemical reactions that might lead to complex kinetic behavior. To check this we repeated a run with the UV light intensity decreased by a factor of ten using simple plastic filters. Although there were some minor differences, the "induction time" and sharp drop in absorbance were similar for the two runs, indicating that photochemical effects are probably minor.

We found one effect that is definitely an experimental artifact, but which is also instructive. Many of the initial runs used a $\mathrm{pH} 3.0$ buffer made from $10 \mathrm{mM}$ chloroacetate/chloroacetic acid. This is a standard buffer and is reasonably stable as a stock solution. However, we found that buffer solutions to which mercuric ion had been added and allowed to stand for several days gave strange but reproducible results, as shown in Figure 24. In the figure, both solutions had 10 $\mathrm{mM} \mathrm{NaCl}, 1.0 \mathrm{mM}$ sulfite, $10 \mathrm{mM} \mathrm{pH} 3.0$ buffer, and $50 \mathrm{mM} \mathrm{NaClO}_{4}$, and were run at $55^{\circ} \mathrm{C}$.

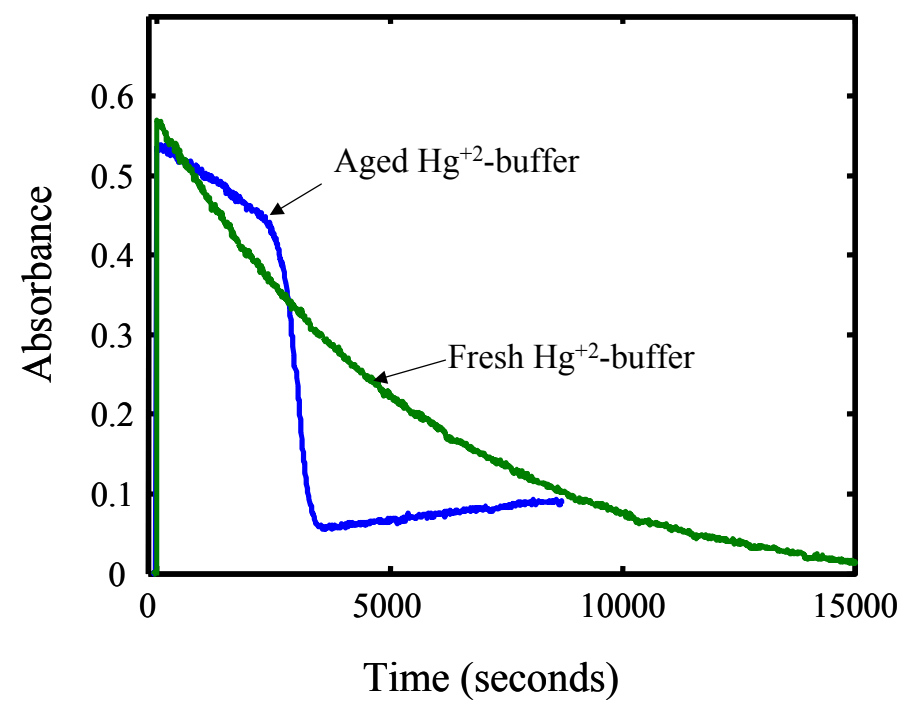

Figure 24. Comparison of Time Profiles for Fresh Chloroacetate Buffer and Buffer Exposed to Mercuric Ion for Several Days 
No such problems have been experienced with acetic acid buffers used at $\mathrm{pH}$ 4-5 or with unbuffered solutions. In retrospect, mercuric ion is probably a good catalyst for the hydrolysis of chloroacetic acid, since it would tend to extract the chlorine atom, leaving a carbonium ion that is very labile for hydrolysis. The likely product would be glycolic acid or glycolate. This species might then chelate or react with mercuric ion, leading to the effects shown. The "bad buffer" compound noticeably enhances the "inductive time" behavior, leading to a sharp drop in absorbance at times much shorter than normally seen in $10 \mathrm{mM}$ chloride solutions.

\section{Macro Cell Results}

A "macro cell" was constructed and checked out as an experimental enhancement as well as check on some of the previous "micro" scale (2-mL reaction volume) UV absorbance results. The cell was designed to allow simultaneous and continuous measurement of UV absorbance, open circuit potential (OCP, or "redox potential"), $\mathrm{pH}$, and temperature. In the micro cell described earlier in this report, only UV absorbance and temperature could be monitored. The volume of the macro cell is large enough $(100 \mathrm{~mL})$ to allow periodic sampling during a run with subsequent measurement of sulfite/sulfate by ion chromatography.

Results from a macro-cell run starting with $10 \mathrm{mM}$ chloride buffered to $\mathrm{pH} 4.0$ with $20 \mathrm{mM}$ acetate, adding first $40 \mu \mathrm{M} \mathrm{Hg}^{+2}$ and then $1.0 \mathrm{mM}$ sulfite at $55^{\circ} \mathrm{C}$, is shown in Figure 25 . The absorbance time profile for this run agrees fairly well with that obtained for 12,000 seconds in the micro cell. The OCP changes show both the effect of adding the "oxidizing" mercuric ion (increase in OCP) and the sulfite (negative shift in OCP). The changes in OCP as the reaction proceeds are relatively small and practically imperceptible at the scale of this figure. However, from several run results it appears that OCP changes due to the effects of mercuric complexes may be discernible. Generally, a slow increase in OCP can be seen at long times as sulfite is consumed (see the right side of Figure 25 below).

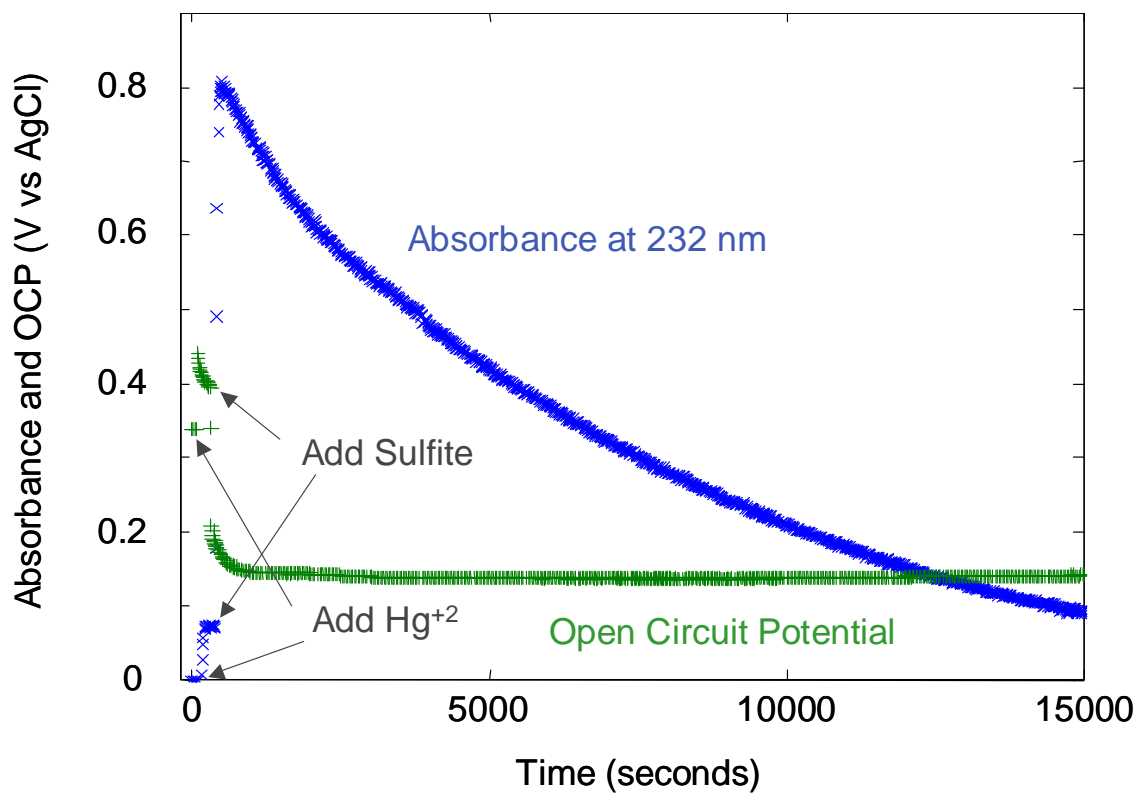

Figure 25. Absorbance and OCP on Addition of $40 \mu \mathrm{M} \mathrm{Hg}^{+2}$ and $1.0 \mathrm{mM}$ Sulfite to Solution Containing $10 \mathrm{mM}$ Chloride and $20 \mathrm{mM}$ Acetate Buffer $\left(55^{\circ} \mathrm{C}, \mathrm{pH} \mathrm{4.1)}\right.$ 
Although the spectrophotometric results agree for this case, some of the micro-cell results show abrupt variations during the run, particularly at higher chloride concentrations. These abrupt transitions were not observed in the larger macro cell. A contributing factor may be $\mathrm{pH}$ excursions when sulfite is added to unbuffered solutions, which have been observed with the continuous $\mathrm{pH}$ monitoring that is possible with the macro cell. Checks of the $\mathrm{pH}$ in the micro cell after each run show it is usually near the starting $\mathrm{pH}$ (before sulfite addition). But this may be fortuitous and due to acidification that occurs on sulfite oxidation, which was observed to occur during the course of a run in the macro cell (see below). Buffers have been used for all runs above $\mathrm{pH} 3.5$, but problems have been encountered with low $\mathrm{pH}$ buffers, as discussed above.

Another unexpected phenomenon observed in the macro-cell runs is the oxidation of sulfite that occurs noticeably over long run periods, even with careful initial purging and then blanketing of the reaction liquid with nitrogen. At long run times (10,000 to 15,000 seconds), about $50 \%$ of the initial $1.0 \mathrm{mM}$ sulfite is oxidized to sulfate, as determined by ion chromatograph measurements. Possible causes of the unexpected oxidation, such as photo-oxidation or oxygen diffusion through cell tubing were investigated. The effect appears to be due to oxygen diffusion, since sulfite oxidation was not affected by turning off the light source, but it was eliminated when the solution was not pumped to and from the spectrophotometric cuvette.

\section{Stripping Rate Tests}

\section{Short-term Tests}

An additional measurement approach was developed to collect data on the time evolution of gas phase elemental mercury produced by the reaction, in what are called "stripping rate" tests in this report. Results are shown in Figure 26 for a run at $50{ }^{\circ} \mathrm{C}$, which had an initial $\mathrm{pH}$ of 3.0 and was saturated with $184 \mathrm{ppm} \mathrm{SO}_{2}$ in the gas phase. At " $\mathrm{t}=0$ " in the graph, an aliquot of mercuric perchlorate was injected into the solution to give an initial liquid phase concentration of $0.5 \mu \mathrm{M}$ $\mathrm{Hg}^{2+}$. As shown, elemental mercury starts to be evolved at once, reaches a peak, and then shows a decline similar in shape to the spectrophotometric decay curves of the mercuric sulfite complex. After the run, the solution $\mathrm{pH}$ was 2.65 and and the liquid contained $0.93 \mathrm{mM}$ sulfite, reasonably close to the target of $1.0 \mathrm{mM}$.

A mercury material balance for this run shows that 53 nanomoles $\left(10^{-9} \mathrm{~g}\right.$-moles $)$ of mercuric ion were injected, 4 nanomoles were remaining in the liquid after the run, and 57 nanomoles of $\mathrm{Hg}^{0}$ were recovered from the gas phase based on integration of the data in Figure 26, giving an overall recovery of $116 \%$. This appears to be good closure although subsequent efforts were made to tighten up the measurements to improve closure. Liquid phase mercury measurements for four other similar runs were all lower than 2.2 nanomoles, indicating that most of the mercury is "re-emitted" under these conditions. 


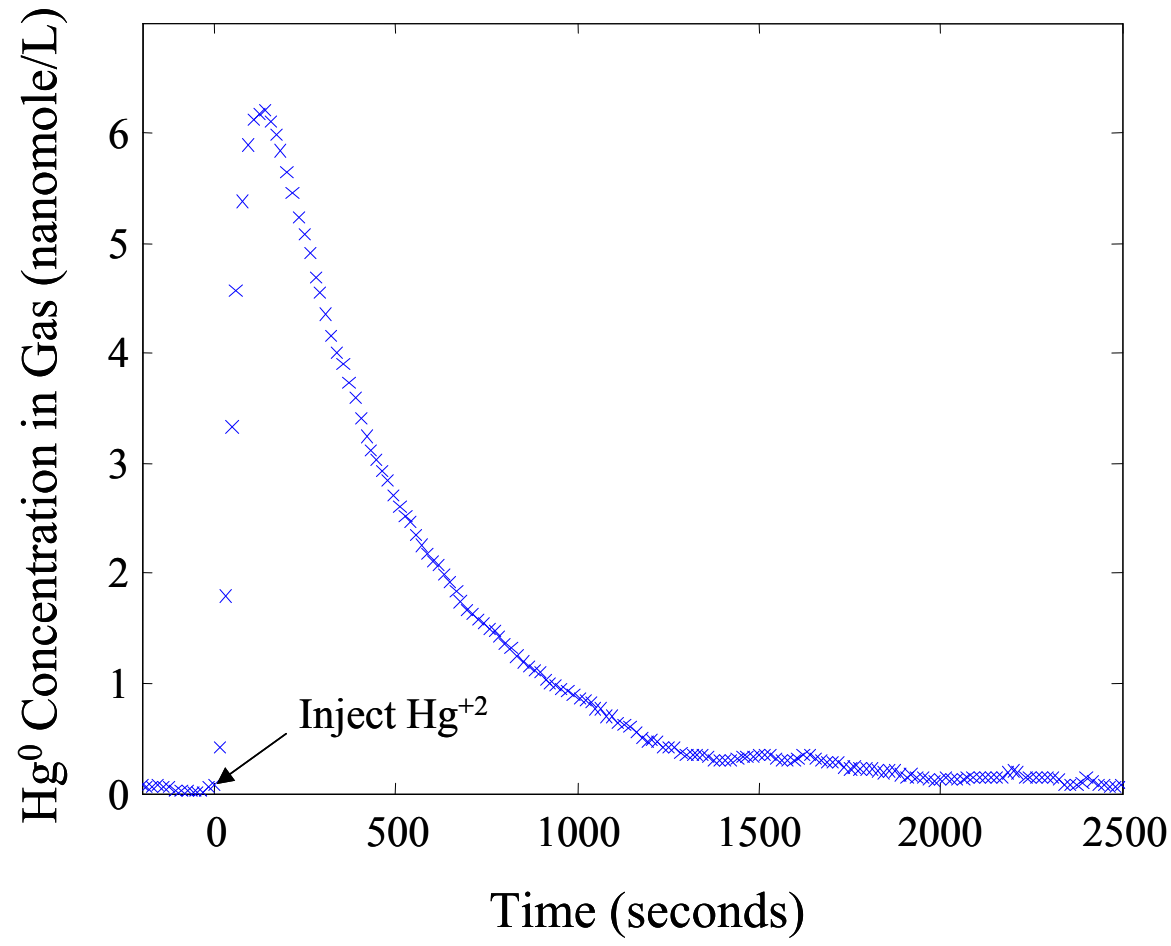

Figure 26. Evolution of Gas Phase $\mathrm{Hg}^{0}$ from Reaction at $50{ }^{\circ} \mathrm{C}$ (initially at $\mathrm{pH} 3.0$ and spiked with $0.5 \mu \mathrm{M} \mathrm{Hg}^{2+}$; $184 \mathrm{ppm} \mathrm{SO} \mathrm{S}_{2}$ in gas; $\mathrm{pH} 2.65$ and $0.93 \mathrm{mM}$ sulfite in liquid after the run)

The apparatus was subsequently modified to measure gas phase mercury concentrations continuously without using absorption/stripping of the mercury on/from gold. The gas phase $\mathrm{Hg}^{0}$ is measured directly in a $17.5 \mathrm{~cm}$ flow tube using a $254 \mathrm{~nm}$ mercury lamp source and photomultiplier detector. The absorptivity of gas phase $\mathrm{Hg}^{0}$ was taken as $4.1 \times 10^{6} \mathrm{~L} /(\mathrm{gmole}$ $\mathrm{cm}){ }^{4}$ This approach provides a more direct measurement and much shorter time between measurements. It also makes the equipment simpler and more reliable.

Typical results obtained with this equipment are shown in Figure 27 for three different levels of $\mathrm{Hg}^{+2}$ injected at $\mathrm{t}=0$. These runs were done at $55^{\circ} \mathrm{C}$ with $124 \mathrm{ppm} \mathrm{SO}_{2}$, balance $\mathrm{N}_{2}$ in the gas passing through the absorber, sulfite level of $1.3 \mathrm{mM}$, and $\mathrm{pH}$ of 3.1 . 


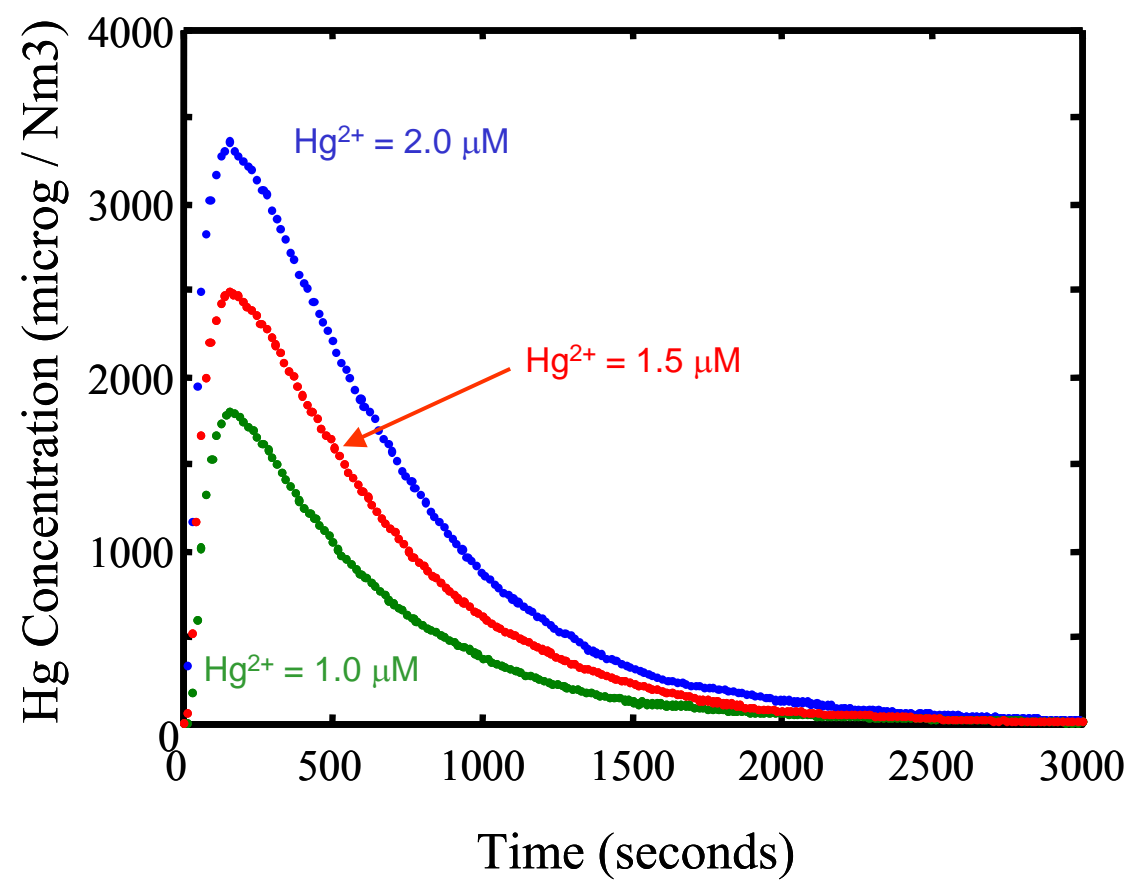

Figure 27. $\mathrm{Hg}^{0}$ Stripping Kinetics Results for Addition of 1.0, 1.5, and $2.0 \mathrm{mM} \mathrm{Hg}^{+2}$ to Solution Containing $1.3 \mathrm{mM}$ Sulfite at pH 3.1, with $124 \mathrm{ppm} \mathrm{SO} \mathrm{S}_{2}$ in Gas Phase at $55^{\circ} \mathrm{C}$

As shown in Figure 27, elemental mercury starts to evolve at once, reaches a peak, and then shows a decline similar in shape to the spectrophotometric decay curves of the mercuric sulfite complex that have been shown previously. Values of the "observed" rate constant, $\mathrm{k}_{\mathrm{obs}}$, were calculated from the slope of the natural log of absorbance versus time in the absorbance decay region of the figure. For these three runs the $\mathrm{k}_{\mathrm{obs}}$ was essentially the same, $2.0 \pm 0.15 \times 10^{-3} \mathrm{sec}^{-1}$, as would be expected for a reaction that is first order in dissolved $\mathrm{Hg}^{+2}$ overall. This is also in very good agreement with the $\mathrm{k}_{\mathrm{obs}}$ calculated from the corresponding spectrophotometric experiment, $3 \times 10^{-3} \mathrm{sec}^{-1}$ (which would be expected to be somewhat higher since it was done at lower sulfite concentration, $1.0 \mathrm{mM}$ vs. $1.3 \mathrm{mM}$ ).

The effect of adding $10 \mathrm{mM}$ chloride on the stripping kinetics is shown in Figure 28. As expected from the spectrophotometric work, both the amount of $\mathrm{Hg}$ stripped and the rate of stripping was lowered drastically. The average $\mathrm{k}_{\mathrm{obs}}$ from three stripping runs is $1.7 \pm 0.7 \times 10^{-4}$ $\mathrm{sec}^{-1}$ and is again in good agreement with the spectrophotometric value of about $2 \times 10^{-4} \mathrm{sec}^{-1}$. 


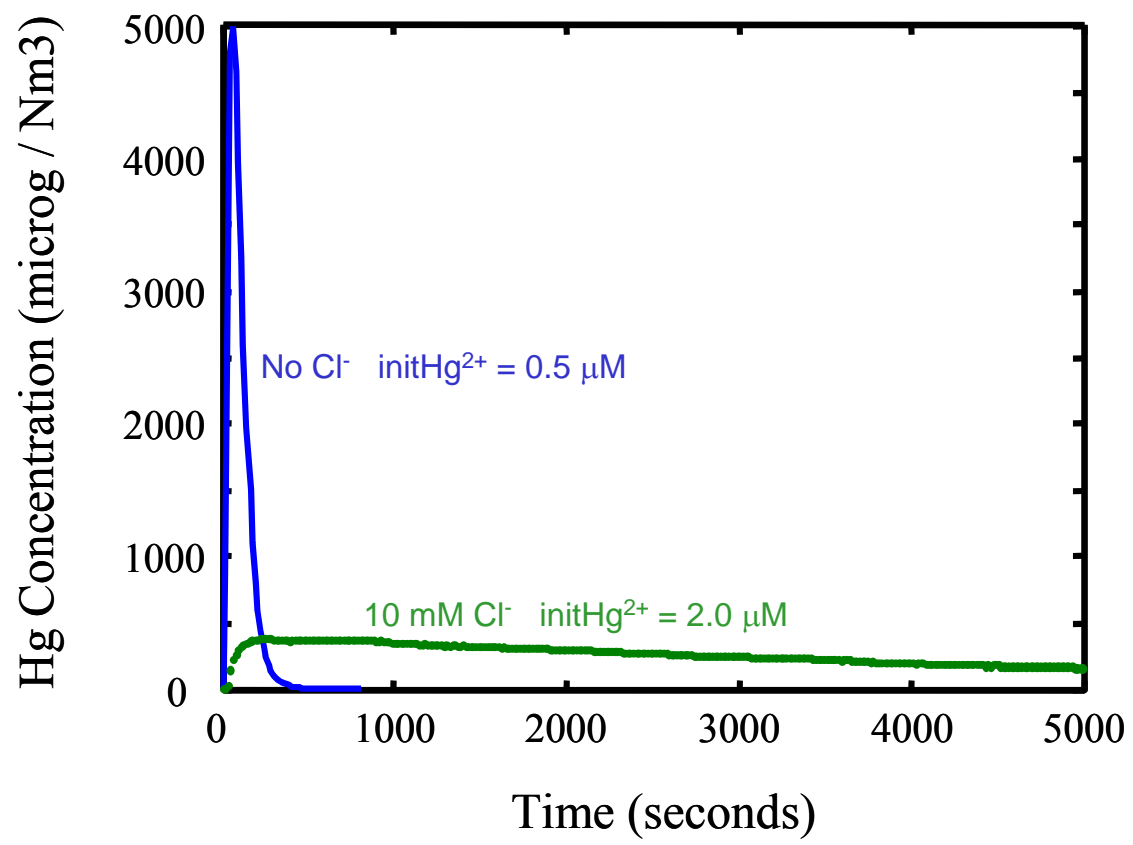

Figure 28. Stripping Kinetics Results with and without $10 \mathrm{mM}$ Chloride at $55^{\circ} \mathrm{C}$

A comparison of stripping kinetics for runs with $10 \mathrm{mM}, 100 \mathrm{mM}$, and $250 \mathrm{mM}$ chloride is shown in Figure 29. The $10 \mathrm{mM}$ chloride run started with an injection of $2.0 \mu \mathrm{M} \mathrm{Hg}^{+2}$; the 100 and $250 \mathrm{mM}$ chloride runs used ten times the initial amount of mercury, from a $20 \mu \mathrm{M} \mathrm{Hg}^{+2}$ injection, to produce measurable vapor phase $\mathrm{Hg}^{0}$ concentrations because of the effects described below.

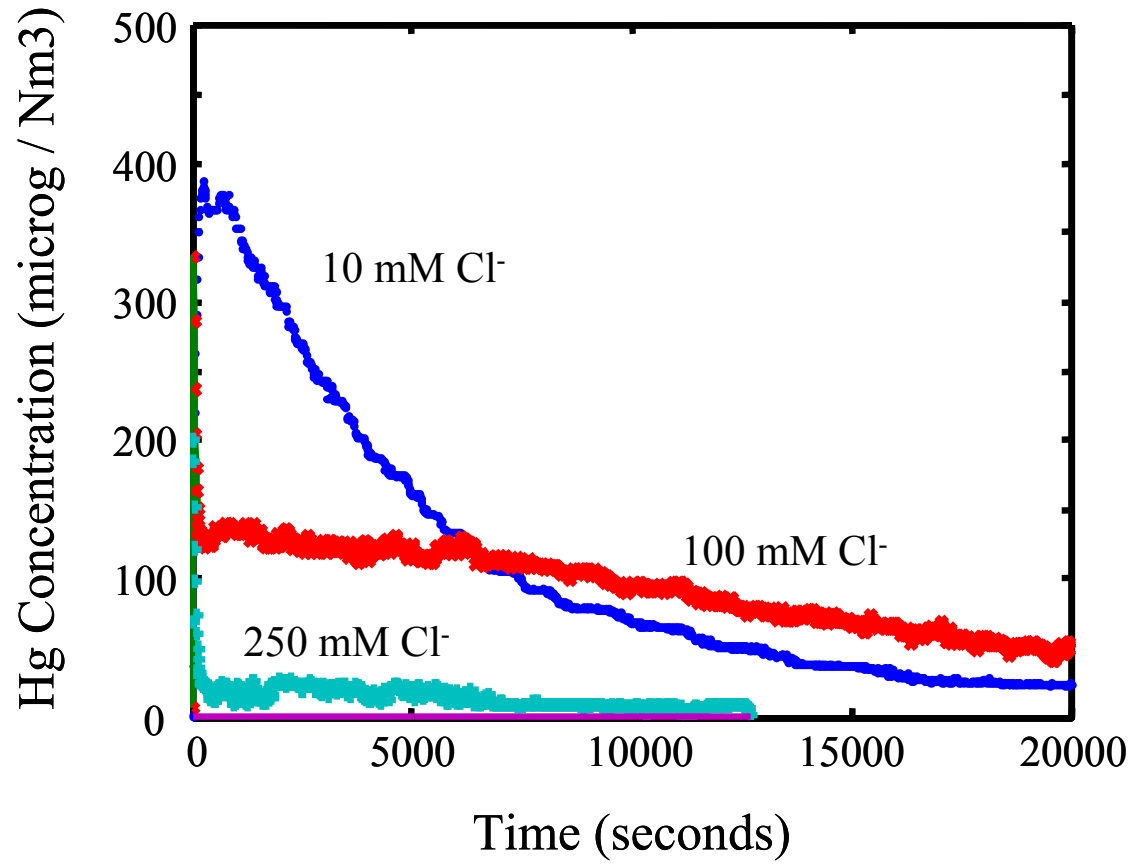

Figure 29. Stripping Kinetics Results with $10 \mathrm{mM}, 100 \mathrm{mM}$ and $250 \mathrm{mM}$ Chloride at $55^{\circ} \mathrm{C}$ 
Again, the data in this figure show that each increasing level of chloride drastically decreases the overall amount and rate of evolution of $\mathrm{Hg}^{0}$ from the solution. Also note that there is typically a "spike" of $\mathrm{Hg}^{0}$ released at the very start of the run. It is tempting to associate this with the spike in absorbance seen at the start of many of the high chloride spectrophotometric runs, but more work to establish a relationship would be desirable.

The sorbent liquids from the stripping kinetics runs were analyzed for mercury after each run by cold vapor atomic absorption. As shown in Figure 30, over 99.5\% of the mercury was stripped out of the solution in the 0 and $10 \mathrm{mM}$ chloride cases. For the $100 \mathrm{mM}$ chloride case only $37 \%$ of the added mercury was stripped and for the $250 \mathrm{mM}$ chloride case less than $3 \%$ was stripped after a total run duration of more than 50 hours. To put these chloride concentrations into the perspective of typical FGD liquor chloride concentrations, $10 \mathrm{mM}(\sim 350 \mathrm{ppm})$ would represent a very low FGD chloride ion concentration, while $100 \mathrm{mM}(\sim 3550 \mathrm{ppm})$ would represent a midrange value for an FGD system with a moderate chloride purge rate. The highest value of 250 $\mathrm{mM}(\sim 8860 \mathrm{ppm})$ is not atypically high for FGD systems with a lower chloride purge rate (e.g., systems that produce wallboard-grade gypsum), which could range up to several times that chloride concentration.

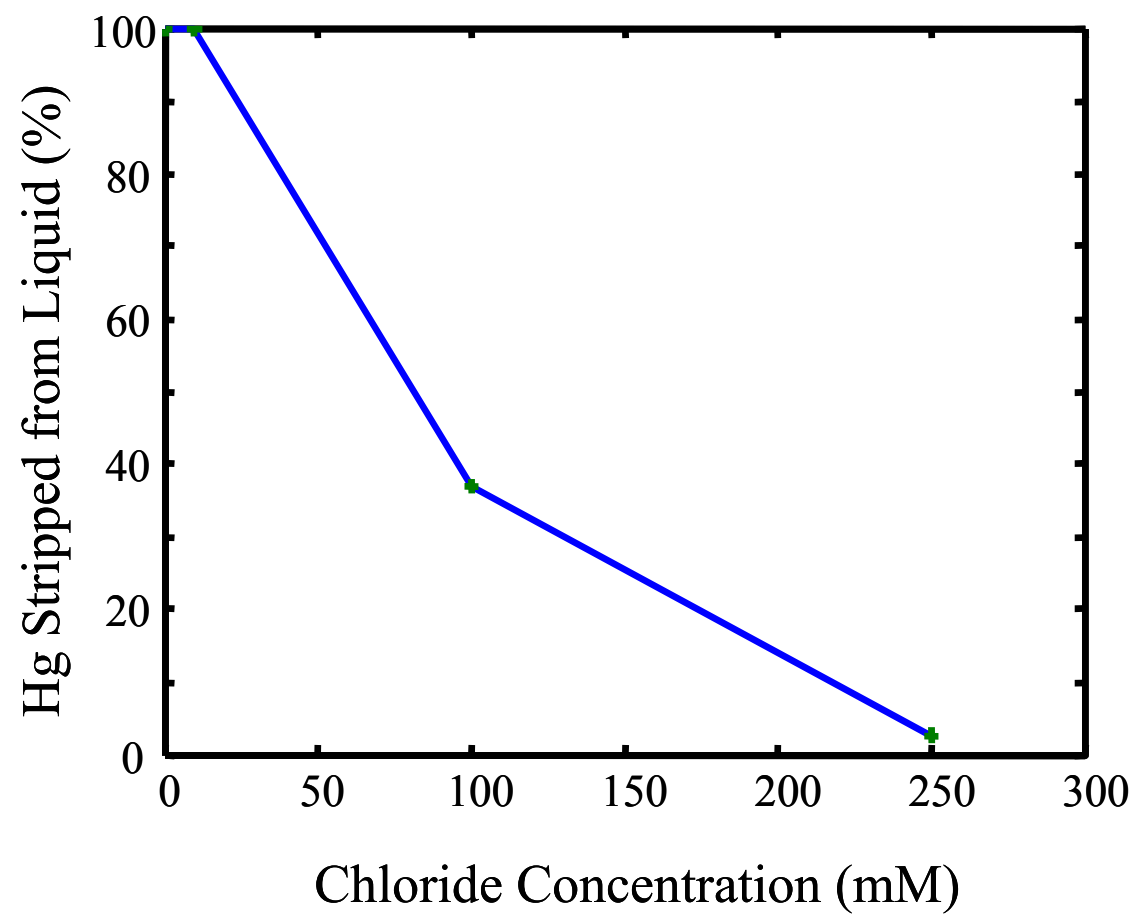

Figure 30. Percentage of Mercury Stripped from Solution, as a Function of Chloride Concentration

We briefly investigated the effects of thiosulfate ion (present in inhibited oxidation FGD liquors) on mercury reduction using the stripping kinetics method. The mercuric-thiosulfate complexes are strong and have high UV absorbance, complicating spectrophotometric measurement even at low thiosulfate concentrations. Results of a stripping kinetics run using $1.0 \mathrm{mM}$ thiosulfate added to a $100 \mathrm{mM}$ chloride solution are compared in Figure 31 to those obtained without thiosulfate 
but also with $100 \mathrm{mM}$ chloride; both were spiked with $20 \mu \mathrm{M} \mathrm{Hg}^{+2}$. Note that $1.0 \mathrm{mM}$ of thiosulfate $(\sim 110 \mathrm{ppm})$ is a relatively low concentration compared to typical values in inhibited oxidation FGD liquors, where values of $1000 \mathrm{ppm}$ and higher are common.

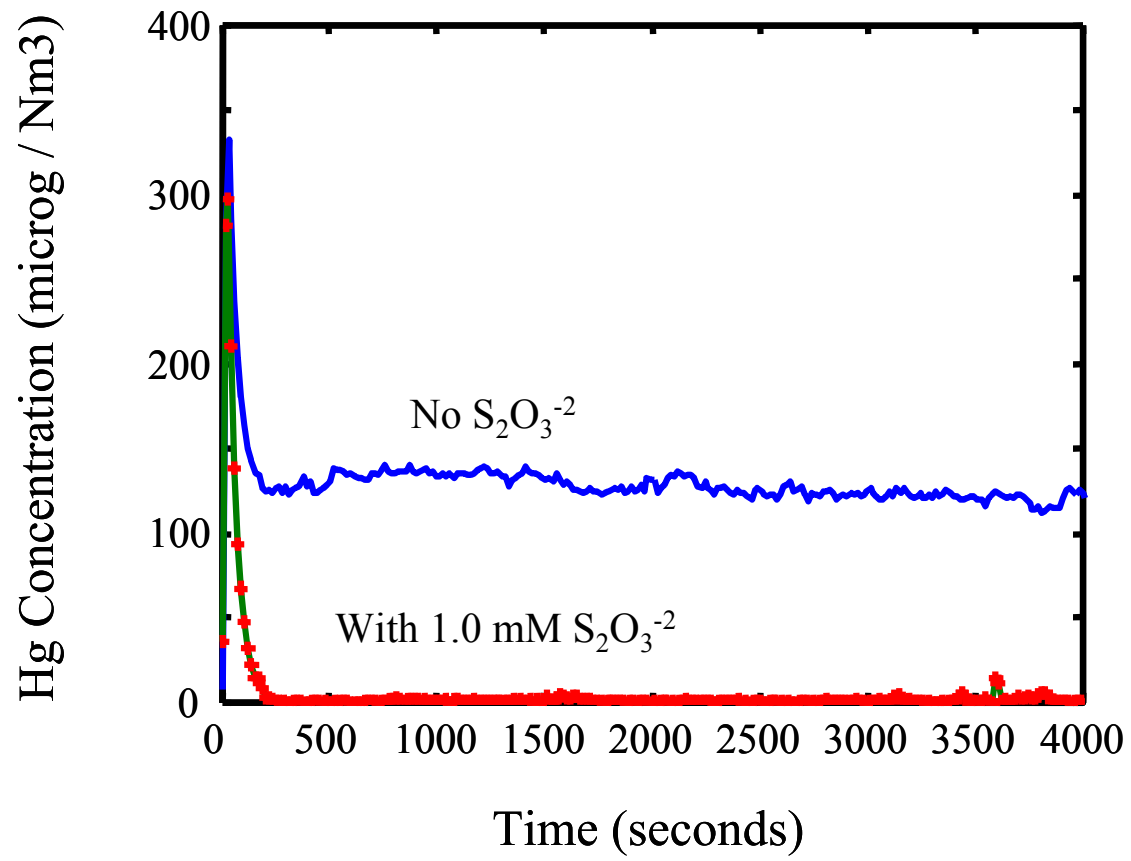

Figure 31. Effect of Adding $1.0 \mathrm{mM}$ Thiosulfate to a $100 \mathrm{mM}$ Chloride Solution on $\mathrm{Hg}^{0}$
Stripping Kinetics

As can be seen, the initial sharp stripping peak is very similar in the two cases. In the case without thiosulfate there follows a period of fairly steady evolution of $\mathrm{Hg}^{0}$. In the thiosulfate case, however, the $\mathrm{Hg}^{0}$ evolution essentially goes to zero after the initial spike. Analysis of the thiosulfate solution for mercury concentration indicated that less than $10 \%$ of the original mercury had been stripped after over 21 hours. Less than $0.1 \%$ of the added mercury could be accounted for in the gas phase for this run. Thus, it appears that even low concentrations of thiosulfate inhibit $\mathrm{Hg}^{0}$ evolution under these conditions, probably due to formation of mercuricthiosulfate complexes which are stable and which block the more rapid reduction pathways involving chloromercuric sulfite complexes.

Another interesting example of effects of a strong complexing agent is shown in a run done with only $80 \mu \mathrm{M}$ iodide ( $\sim 10 \mathrm{ppm})$, which is compared to results with $80 \mu \mathrm{M}$ of chloride ( $\sim 3 \mathrm{ppm}$ ) under the same $\mathrm{pH}$ 3.0, $1.0 \mathrm{mM}$ sulfite, and $55^{\circ} \mathrm{C}$ conditions in Figure 32. 


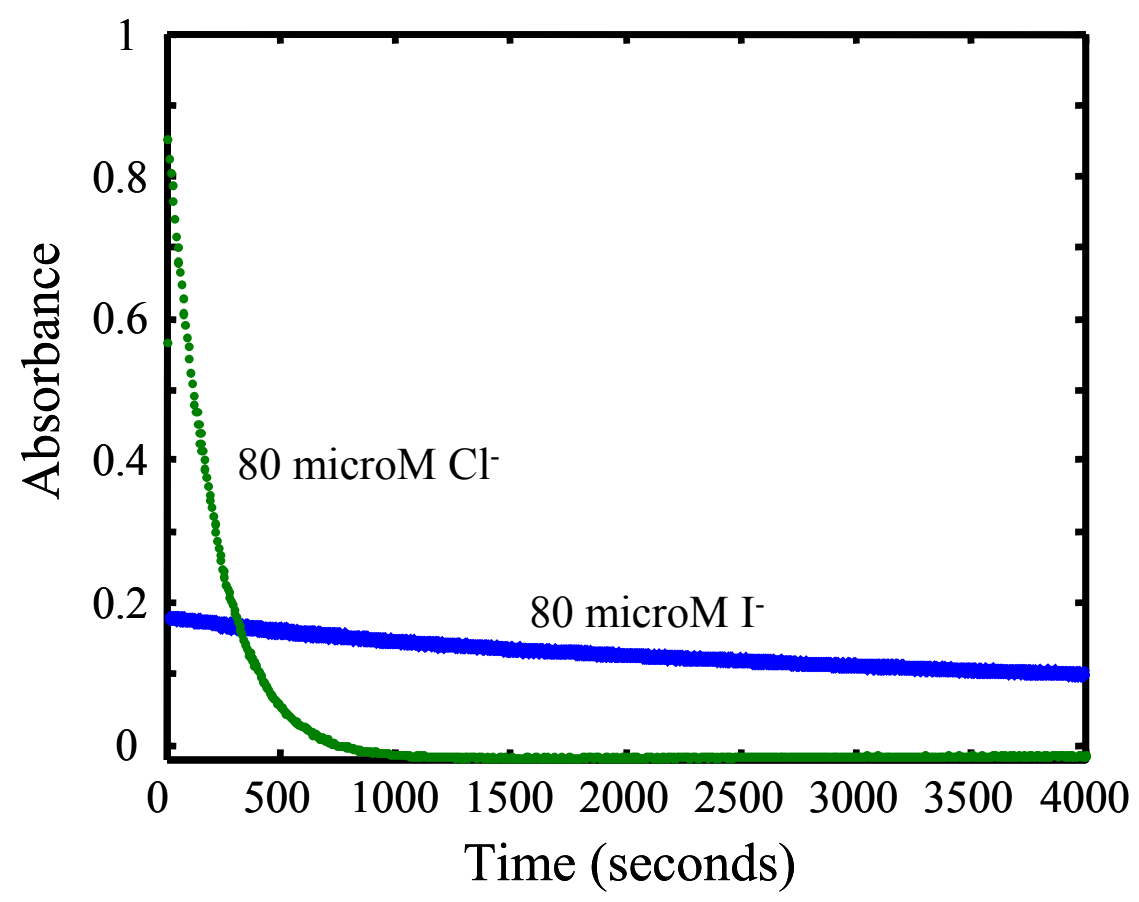

Figure 32. Comparison of Effects of $80 \mu \mathrm{M}$ lodide and $80 \mu \mathrm{M}$ Chloride on Kinetics of Mercuric Ion Reduction

The response with $80 \mu \mathrm{M}$ chloride is similar to and about as fast as without chloride, indicating that chloride cannot compete very well with sulfite in complexing (and reducing) mercuric ion at this low concentration. However, iodide, which is known to be a very strong complexing agent for mercuric ion, reduces the rate of reaction substantially. The $\mathrm{k}_{\mathrm{obs}}$ for the run with iodide is 1.3 x $10^{-4} \mathrm{sec}^{-1}$, similar to but still somewhat slower than that obtained for the $10 \mathrm{mM}$ chloride runs $(10 \mathrm{mM}$ is 125 times the molar concentration of iodide at $80 \mu \mathrm{M})$.

\section{Longer-term Mercury Stripping Tests}

Most of the stripping runs described above were conducted with cold-vapor atomic absorption measurement of elemental mercury in the gas phase above the solutions, to determine $\mathrm{Hg}^{0}$ evolution rates. However, measurement of gas phase concentrations becomes less accurate for conditions where the reactions are quite slow and gas phase mercury concentrations are low, including many typical FGD process conditions. In a later series of longer-term tests, the apparatus was instead operated in combination with periodic liquor sampling and cold-vapor atomic absorption measurement of oxidized mercury remaining in the liquid phase. Thus, the rate of $\mathrm{Hg}^{0}$ evolution has been determined for these slower reaction rate conditions by determining the rate at which $\mathrm{Hg}$ concentrations drop in the reaction liquor.

For these stripping runs, the apparatus was modified to get better pre-saturation of the gas with water, to minimize water evaporation from the solutions. In addition, these runs employ $100 \mathrm{mM}$ acetate buffer to obtain better $\mathrm{pH}$ stability for the long run times. A set of runs was done to determine the effect of varying $\mathrm{pH}(4.0,5.0$, and 6.0$)$ and sulfite concentration $(1,5$, and $20 \mathrm{mM})$ at a fixed chloride value $(100 \mathrm{mM})$ typical of FGD conditions, over a duration of 24 hours. 
During this series of runs, problems were still encountered in maintaining a constant liquid volume in the reactor due to variations in temperature of the pre-saturator, the long duration of the runs and the high gas stripping rates used to insure complete stripping of elemental mercury as it is formed. To correct for these volume changes the initial and final volumes of liquid in the reactor were measured and each mercury concentration data point was corrected assuming the volume varied linearly with time over the duration of the experiment. Maintaining the $\mathrm{pH}$ and sulfite concentration of these solutions is difficult particularly at higher $\mathrm{pH}(6)$ and lower sulfite concentrations.

Some examples of individual run results obtained using this method are shown in Figure 33. All runs reported below were done using $100 \mathrm{mM}$ sodium chloride and $100 \mathrm{mM}$ sodium acetate at 55 ${ }^{\circ} \mathrm{C}$. The inlet $\mathrm{SO}_{2}$ concentration in the gas mixture was varied from approximately $1 \mathrm{ppm}$ to 200 $\mathrm{ppm}$ to match the calculated equilibrium total sulfite value for the desired $\mathrm{pH}$ and sulfite concentration.

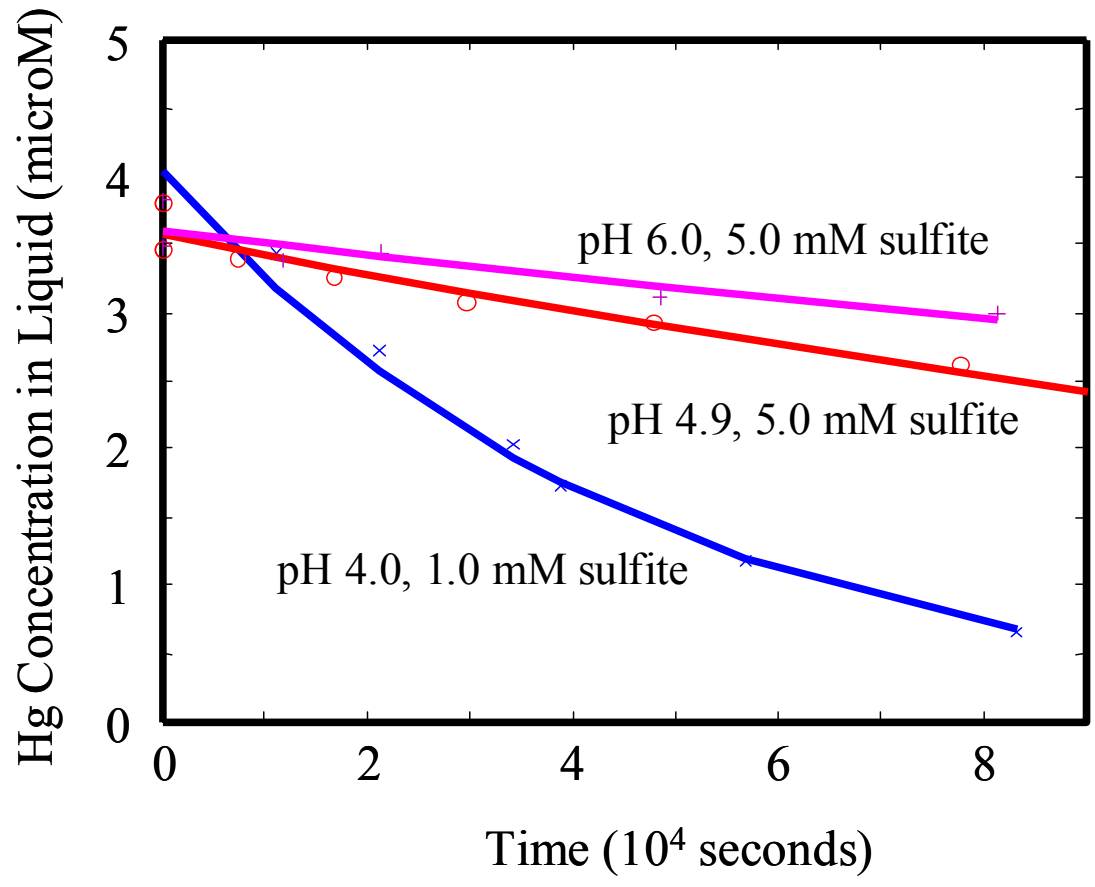

Figure 33. Amount of Mercury Remaining in Solutions of Compositions Shown, also Containing $100 \mathrm{mM} \mathrm{NaCl}$ and $100 \mathrm{mM}$ Acetate Buffer, on Continuous Stripping with $\mathrm{N}_{2}$ $\mathrm{SO}_{2}$ Gas Mixture (Solution spiked with $4.0 \mu \mathrm{M} \mathrm{Hg}\left(\mathrm{ClO}_{4}\right)_{2}$ at $\mathrm{t}=0$ )

Apparent rate constants, $\mathrm{k}_{\mathrm{obs}}$, were calculated for each run from the negative of the slope of a least squares fit of $\ln \left(\mathrm{C}^{0} / \mathrm{C}\right)$ versus time, where $\mathrm{C}^{0}$ is the initial mercury concentration (nominally $4.0 \mu \mathrm{M})$ and $\mathrm{C}$ is the concentration of mercury measured at each sample time. All of the results obtained thus far are shown in below in Figures 34 through 36, where the results for each sulfite level have been separated out. The error bars shown on the figures represent the standard deviation of the points in each $\ln \left(\mathrm{C}^{0} / \mathrm{C}\right)$ versus time curve. Since there was some variation in $\mathrm{pH}$ during the runs, results are plotted for both the initial $\mathrm{pH}$ (symbol "x") and final $\mathrm{pH}$ (symbol "o") values. All three plots are drawn to the same scale to facilitate comparison. The solid lines are from a cubic fit and are only intended to aid visualization. 


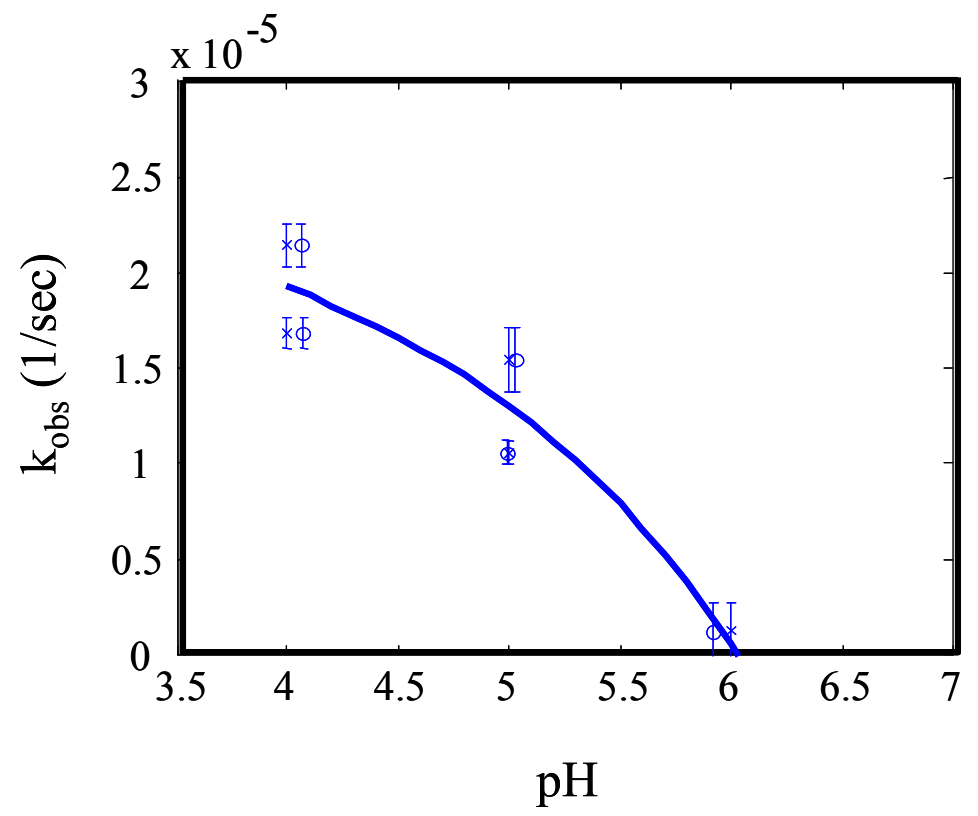

Figure 34. Observed Rate Constants for Reduction and Stripping of Mercury in $1.0 \mathrm{mM}$ Sodium Sulfite Solutions as a Function of pH. (Solutions contained $100 \mathrm{mM} \mathrm{NaCl}$ and 100 $\mathrm{mM}$ sodium acetate at $\left.55^{\circ} \mathrm{C}\right)$.

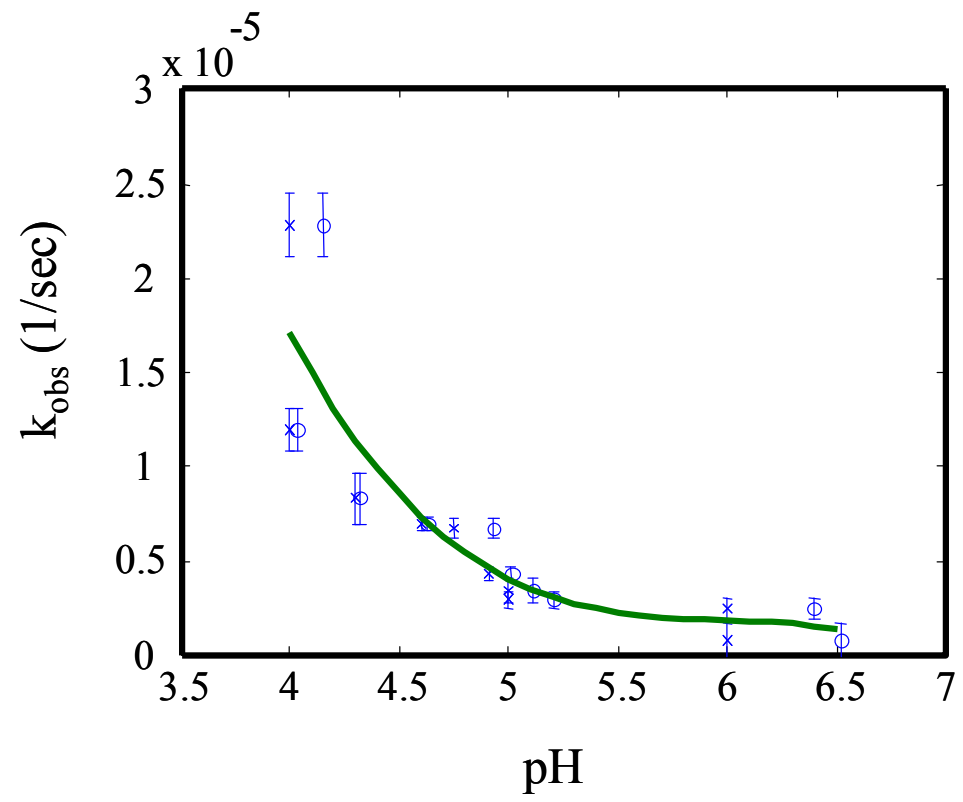

Figure 35. Observed Rate Constants for Reduction and Stripping of Mercury in $5.0 \mathrm{mM}$ Sodium Sulfite Solutions as a Function of pH. (Solutions contained $100 \mathrm{mM} \mathrm{NaCl}$ and 100 $\mathrm{mM}$ sodium acetate at $\left.55^{\circ} \mathrm{C}\right)$. 


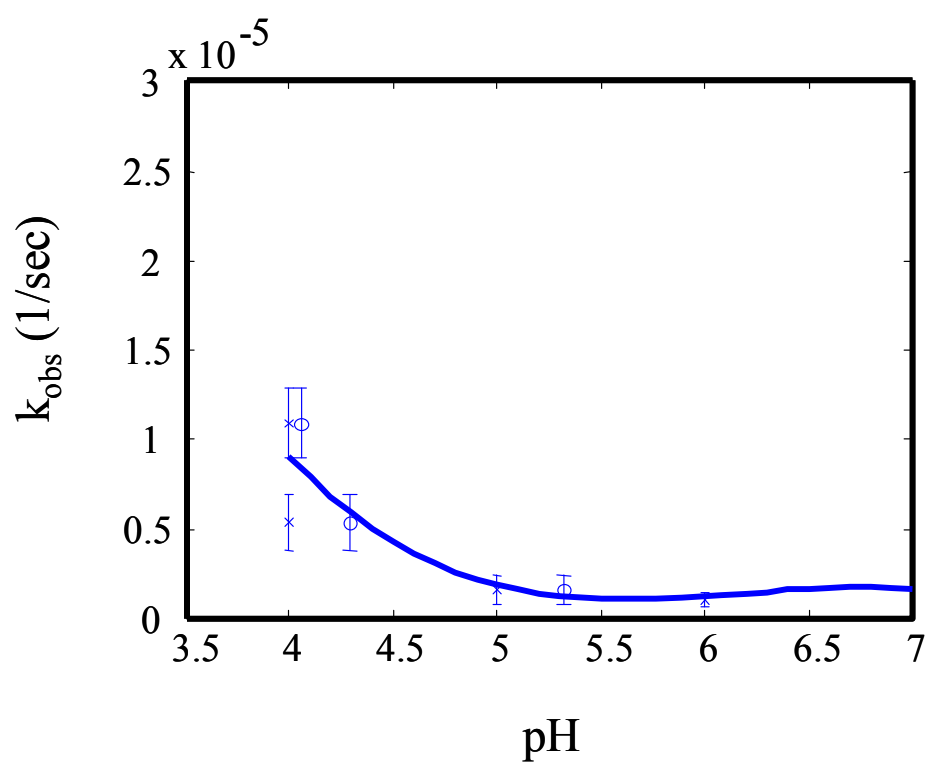

Figure 36. Observed Rate Constants for Reduction and Stripping of Mercury in $20 \mathrm{mM}$ Sodium Sulfite Solutions as a Function of pH. (Solutions contained $100 \mathrm{mM} \mathrm{NaCl}$ and 100 $\mathrm{mM}$ sodium acetate at $\left.55^{\circ} \mathrm{C}\right)$.

Apparent first order rate constants, $\mathrm{k}_{\mathrm{obs}}$, were calculated for each run from the first order rate fits. Results are shown in Figure 37. Since there was some variation in $\mathrm{pH}$ during the high $\mathrm{pH}$ runs in particular, results are plotted for both the initial $\mathrm{pH}$ and final $\mathrm{pH}$, joined by a horizontal line for clarity as needed. The lines and solid markers show results obtained from the kinetics model, basing the corresponding $\mathrm{k}$ values on the rate of formation of $\mathrm{Hg}^{0}$ predicted by the model.

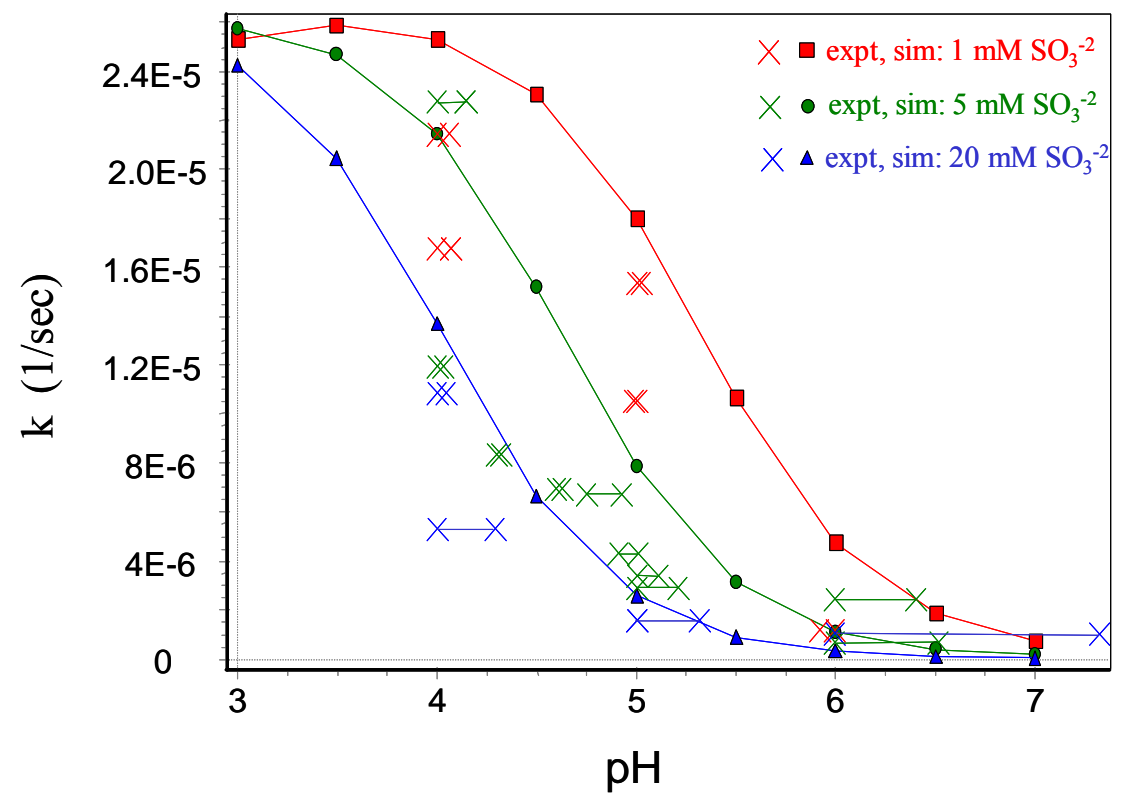

Figure 37. Observed and Model-Simulated Rate Constants for Reduction and Evolution of Mercury in 1.0, 5.0, and $20 \mathrm{mM}$ Sodium Sulfite Solutions as a Function of pH. (Solutions contained $100 \mathrm{mM} \mathrm{NaCl}$ and $100 \mathrm{mM}$ sodium acetate at $55^{\circ} \mathrm{C}$ ) 
These results show that the rate of reduction of oxidized mercury increases significantly (by a factor of about ten) as the $\mathrm{pH}$ decreases from about 5 to 6 down to $\mathrm{pH} 4$ in the presence of 100 $\mathrm{mM}$ chloride. This is consistent with the results obtained at low chloride values using the spectrophotometric method. Although there is considerable scatter, the shape of the rate constant versus $\mathrm{pH}$ curve appears to depend on the sulfite concentration. In general, the rate decreases with increasing sulfite concentration, though the dependence seems to be more pronounced in the transition region between high and low $\mathrm{pH}$. The behavior shown here could be particularly relevant to actual FGD systems since it would indicate that the fastest elemental mercury reemission rates would occur in the absorber and could even vary with type of absorber, position in the absorber, or FGD chemistry.

As an example, in limestone reagent spray-tower absorbers, the absorber recycle slurry is fed to the spray nozzles at a $\mathrm{pH}$ value of about 5.5. As slurry droplets fall through the absorber, countercurrent to the flue gas flow, the droplets are exposed to inlet flue gas with a high inlet $\mathrm{SO}_{2}$ concentration, and the droplet $\mathrm{pH}$ decreases significantly. Values of $\mathrm{pH} 3$ or less are possible. However, in absorbers that operate with high liquid phase alkalinity, such as with magnesium-enhanced lime reagent or with dibasic acid additives, the $\mathrm{pH}$ drop can be much less significant. Similarly, absorber types other than open spray towers may have significantly different droplet $\mathrm{pH}$ profiles.

\section{Task 3: Model Refinement, Bench-scale Validation and Additive Testing}

After the spectrophotometric and mercury stripping runs were mostly completed and a relatively robust kinetics models was developed, the Task 3 bench-scale model validation effort was begun. The initial test plan is discussed below.

\section{Test Plan}

A series of bench scale runs was conducted to determine causes of mercury re-emissions from FGD absorbers and to check and calibrate the chemical kinetics model for predicting such emissions. The test series initially concentrated on the effects of chloride concentration, sulfite concentration, and $\mathrm{pH}$ on $\mathrm{Hg}$ emissions from simulated FGD solutions. Based on lab runs and modeling, chloride is expected to have a dominant effect. For the first series of runs the liquor chloride concentration was fixed at $100 \mathrm{mM}$ (approximately $3500 \mathrm{ppm}$ ), which appears to be a "tipping point" concentration and is also fairly typical of many FGD systems. Following this series, higher and lower concentrations of chloride were tested with somewhat smaller test matrices. Then the effects of other factors which could influence $\mathrm{Hg}$ emissions such as $\mathrm{NO} / \mathrm{NO}_{2}$, thiosulfate, solids, re-emission inhibitor additives (e.g., TMT-15, EDTA), other FGD species $\left(\mathrm{Mg}^{+2}\right.$ and $\left.\mathrm{Ca}^{+2}\right)$, and gas/liquid interface conditions (including inlet $\mathrm{SO}_{2}$ concentration and bubble height/area) were tested under conditions selected from the first test matrix results.

Most tests were done using a "clear liquid" reagent to allow a better focus on key solution concentration effects without the complications of running with a slurry. Concentrated solutions of sodium hydroxide were used to neutralize the absorbed $\mathrm{SO}_{2}$ and thus control the $\mathrm{pH}$. Baseline conditions for this series of runs are given below: 
Sorbent solution:

- Temperature $131^{\circ} \mathrm{F}$,

- $100 \mathrm{mM} \mathrm{NaCl}$ (varied in some runs),

- $10 \mathrm{mM} \mathrm{Na}_{2} \mathrm{SO}_{4}$ initially added,

- $0.5 \mu \mathrm{M} \mathrm{Hg}^{+2}$ injected as $0.5 \mathrm{mM} \mathrm{Hg}\left(\mathrm{ClO}_{4}\right)_{2}$ solution after steady conditions reached,

- $1 \mathrm{M} \mathrm{H}_{2} \mathrm{O}_{2}$ solution added for sulfite control,

- $4 \mathrm{M} \mathrm{NaOH}$ solution added for $\mathrm{pH}$ control.

Simulated flue gas:

- $15-25 \mu \mathrm{g} / \mathrm{Nm}^{3} \mathrm{HgCl}_{2}$ (typically $0.5 \mu \mathrm{g} / \mathrm{Nm}^{3}$ elemental measured),

- $12 \% \mathrm{CO}_{2}$,

- $3 \% \mathrm{O}_{2}$,

- $1000 \mathrm{ppm} \mathrm{SO}_{2}$,

- $15 \mathrm{ppm} \mathrm{HCl}$,

- $\mathrm{No} \mathrm{NO}_{\mathrm{X}}$,

- Balance nitrogen,

- $24 \mathrm{~L} / \mathrm{min}$ nominal total flow (dry basis).

The main overall reaction for $\mathrm{SO}_{2}$ conversion is:

$\mathrm{SO}_{2}+2 \mathrm{NaOH}+1 / 2 \mathrm{O}_{2}=\mathrm{Na}_{2} \mathrm{SO}_{4}+\mathrm{H}_{2} \mathrm{O}$

Using $24 \mathrm{LPM}$ of simulation gas with a $1000 \mathrm{ppm}$ inlet $\mathrm{SO}_{2}$ concentration consumes about 150 $\mathrm{mL}$ of $4 \mathrm{M} \mathrm{NaOH}$ in a five-hour run. This adds $60 \mathrm{mmol}$ of $\mathrm{Na}_{2} \mathrm{SO}_{4}$ to $5.0 \mathrm{~L}$ of scrubber solution. The runs start with sodium sulfate in solution so the relative amount of salt and sulfate buildup during a run is not significant.

The initial test matrix evaluated the following conditions:

- Chloride: $100 \mathrm{mM}$ as $\mathrm{NaCl}$

- Sulfite: $1.0,5.0$, and $20.0 \mathrm{mM}$ as $\mathrm{Na}_{2} \mathrm{SO}_{3}$

- $\mathrm{pH}: 4.0,5.0,6.0,7.0,8.0$

After this initial test matrix was completed and the results were reviewed, a number of follow-on plans were be prepared and implemented. The follow-on plans explored a wider range of FGD conditions, slurry rather than clear solution operation, the effects of additives, etc., as detailed later in this subsection.

\section{Test Results}

Results of bench-scale wet FGD tests completed as part of this project are shown in Table 1. Although the test numbering goes through Test 153, some test numbers were eliminated due to aborted runs or other reasons. The net number of bench-scale wet FGD test results reported is 140 . 
Table 1. Results of Bench-scale Mercury Re-emission Tests

\begin{tabular}{|c|c|c|c|c|c|c|c|}
\hline \multirow{2}{*}{$\begin{array}{l}\text { Run } \\
\text { Number }\end{array}$} & \multirow[b]{2}{*}{ Brief Description } & \multicolumn{3}{|c|}{ Target Conditions } & \multirow[b]{2}{*}{ Additive } & \multirow{2}{*}{$\begin{array}{l}\mathrm{Hg}^{0} \mathrm{Re}- \\
\mathrm{emitted} \\
\left(\mu \mathrm{g} / \mathrm{Nm}^{3}\right)\end{array}$} & \multirow[b]{2}{*}{ Notes, Issues } \\
\hline & & pH & $(\mathrm{mM})$ & $\begin{array}{l}\text { Chloride } \\
\text { (mM) }\end{array}$ & & & \\
\hline 1 & $\begin{array}{l}\text { Base case - medium } \\
\mathrm{pH} \text { and sulfite, } 100 \\
\mathrm{mM} \mathrm{Cl}\end{array}$ & 5.0 & 5.0 & 100 & None & 1.60 & $\begin{array}{l}\text { Current average value } \\
\text { is } 2.1\end{array}$ \\
\hline 2 & $\begin{array}{l}\text { Lower } \mathrm{pH} \text { than base } \\
\text { case }\end{array}$ & 4.0 & 5.0 & 100 & None & 4.60 & \\
\hline 3 & $\begin{array}{l}\text { Higher } \mathrm{pH} \text { than base } \\
\text { case }\end{array}$ & 6.0 & 5.0 & 100 & None & 1.40 & \\
\hline 4 & $\begin{array}{l}\text { Lower sulfite than } \\
\text { base case }\end{array}$ & 5.0 & 1.0 & 100 & None & 5.80 & \\
\hline 5 & Lower $\mathrm{pH}$, low sulfite & 4.0 & 1.0 & 100 & None & 3.80 & \\
\hline 6 & Higher $\mathrm{pH}$, low sulfite & 6.0 & 1.0 & 100 & None & 3.40 & \\
\hline 7 & $\begin{array}{l}\text { Higher sulfite than } \\
\text { base case }\end{array}$ & 5.0 & 20.0 & 100 & None & 2.00 & \\
\hline 8 & High sulfite, low $\mathrm{pH}$ & 4.0 & 20.0 & 100 & None & 5.60 & $\begin{array}{l}\text { Sulfite dropped during } \\
\text { run and was highly } \\
\text { variable; } \mathrm{Hg} \text { out slowly } \\
\text { decreased }\end{array}$ \\
\hline 9 & High sulfite, high $\mathrm{pH}$ & 6.0 & 20.0 & 100 & None & 0.65 & $\begin{array}{l}\text { Up to } 40 \mathrm{mM} \text { short- } \\
\text { duration sulfite spikes } \\
\text { observed }\end{array}$ \\
\hline 10 & High chloride & 5.0 & 20.0 & 250 & None & 0.91 & \\
\hline 11 & Low chloride & 5.0 & 20.0 & 10 & None & 1.97 & \\
\hline 12 & $\begin{array}{l}\text { With } \mathrm{Mg}^{+2} \text {, high } \\
\text { sulfite }\end{array}$ & 5.0 & 20.0 & 100 & $144 \mathrm{mM} \mathrm{Mg}^{+2}$ & 1.35 & $\begin{array}{l}\text { Re-emit } 0.73 \text { overall; } \\
1.35 \text { for last part with } \\
\text { new impinger in CVAA } \\
\text { train }\end{array}$ \\
\hline 13 & Repeat run 8 & 4.0 & 20.0 & 100 & None & 4.98 & \\
\hline 14 & Repeat run 5 & 4.0 & 1.0 & 100 & None & 4.22 & \\
\hline 15 & With $\mathrm{Mg}^{+2}$, low sulfite & 4.0 & 1.0 & 100 & $200 \mathrm{mM} \mathrm{Mg}^{+2}$ & 7.93 & \\
\hline 16 & Repeat run 1 & 5.0 & 5.0 & 100 & None & 3.59 & \\
\hline 17 & With EDTA & 5.0 & 5.0 & 100 & $1 \mathrm{mM} \mathrm{Na}_{2}$ EDTA & 4.99 & $\begin{array}{l}\mathrm{New} \mathrm{Hg}{ }^{+2} \text { stock; redox } \\
\text { potential } \sim 50 \mathrm{mV}\end{array}$ \\
\hline 18 & With TMT & 5.0 & 5.0 & 100 & $0.15 \mathrm{mM}$ TMT & $0.30^{\star}$ & $\begin{array}{l}\text { Low ORP, strange } \\
\text { outlet HgO peaks - avg }\end{array}$ \\
\hline
\end{tabular}




\begin{tabular}{|c|c|c|c|c|c|c|c|}
\hline \multirow{2}{*}{$\begin{array}{l}\text { Run } \\
\text { Number }\end{array}$} & \multirow[b]{2}{*}{ Brief Description } & \multicolumn{3}{|c|}{ Target Conditions } & \multirow[b]{2}{*}{ Additive } & \multirow{2}{*}{$\begin{array}{l}\mathrm{Hg}^{0} \mathrm{Re}- \\
\mathrm{emitted} \\
\left(\mu \mathrm{gg} / \mathrm{Nm}^{3}\right)\end{array}$} & \multirow[b]{2}{*}{ Notes, Issues } \\
\hline & & pH & $\begin{array}{l}\text { Sultite } \\
\text { (mM) }\end{array}$ & $\begin{array}{l}\text { Cnioriae } \\
\text { (mM) }\end{array}$ & & & \\
\hline & & & & & & & emit $=0.74$ \\
\hline 19 & Repeat run 1 & 5.0 & 5.0 & 100 & None & 2.22 & \\
\hline 20 & $\begin{array}{l}\text { With bromide instead } \\
\text { of } \mathrm{Cl}^{-}\end{array}$ & 5.0 & 5.0 & 0 & $100 \mathrm{mM} \mathrm{NaBr}$ & 0.69 & \\
\hline 21 & With lower TMT conc & 5.0 & 5.0 & 100 & $0.01 \mathrm{mM}$ TMT & $\sim 0$ to $\sim 32$ & $\begin{array}{l}\text { With lower TMT conc; } \\
\text { big initial } \mathrm{Hg}^{0} \text { peak }\end{array}$ \\
\hline 22 & $\begin{array}{l}\text { Low Cl-, medium } \\
\text { sulfite }\end{array}$ & 5.0 & 5.0 & 10 & None & 3.78 & \\
\hline 23 & $\begin{array}{l}\text { Sodium diethyldithio- } \\
\text { carbamate }\end{array}$ & 5.0 & 5.0 & 100 & $0.15 \mathrm{mM}$ DEDTC & 0.68 & $\begin{array}{l}\text { Early Hg peak may be } \\
\text { due to transition from } \\
\text { very high to lower } \\
\text { sulfite }\end{array}$ \\
\hline 25 & $\begin{array}{l}\text { Repeat run } 1 \text { except } \\
\text { inject } 0.25 \mathrm{uM} \mathrm{Hg}^{+2}\end{array}$ & 5.0 & 5.0 & 100 & None & 1.60 & \\
\hline 26 & $\begin{array}{l}\text { Repeat run } 1 \text { except } \\
\text { inject } 1.0 \mathrm{uM} \mathrm{Hg}{ }^{+2}\end{array}$ & 5.0 & 5.0 & 100 & None & 3.70 & \\
\hline 27 & With NOx & 5.0 & 5.0 & 100 & $\begin{array}{l}260 \mathrm{ppm} \mathrm{NO} \text { with } \\
15 \mathrm{ppm} \mathrm{NO} \mathrm{N}_{2}\end{array}$ & 0.72 & $\begin{array}{l}\text { Varies: } 0.5-1.3 \text { and } \\
\text { going down }\end{array}$ \\
\hline 28 & High pH & 7.0 & 5.0 & 100 & None & 0.99 & \\
\hline 29 & With fly ash & 5.0 & 5.0 & 100 & Fly ash & 2.01 & \\
\hline 30 & With adipic acid & 5.0 & 5.0 & 100 & $\begin{array}{l}3.4 \mathrm{mM} \text { adipic } \\
\text { acid }\end{array}$ & 4.06 & Very stable \\
\hline 31 & $\begin{array}{l}\text { Repeat run } 1 \text { except } \\
\text { inject } 1.5 \mathrm{uM} \mathrm{Hg++;} \\
\text { run longer before } \\
\text { injection to get } 0 \\
\text { point }\end{array}$ & 5.0 & 5.0 & 100 & None & 6.16 & $\begin{array}{l}\text { Measured } 0.44 \\
\text { ug/ } / \mathrm{Nm}^{3} \text { before } \mathrm{Hg}^{+2} \\
\text { injected; sulfite noisy }\end{array}$ \\
\hline 32 & With formic acid & 5.0 & 5.0 & 100 & $\begin{array}{l}7.25 \mathrm{mM} \mathrm{Na} \\
\text { formate }\end{array}$ & very high & $\begin{array}{l}\text { Emits } 10 \text { just with } \\
\mathrm{HgCl}_{2} \text { in gas }\end{array}$ \\
\hline 33 & $\begin{array}{l}\text { With intermediate } \\
\text { TMT conc }\end{array}$ & 5.0 & 5.0 & 100 & 0.05 mM TMT & 14 to $\sim 1.5$ & $\begin{array}{l}\text { Average after peak is } \\
1.9\end{array}$ \\
\hline 34 & With TMT + MgCl2 & 5.0 & 5.0 & 100 & $\begin{array}{l}0.05 \mathrm{mM} \mathrm{TMT}+ \\
200 \mathrm{mM} \mathrm{MgCl}_{2}\end{array}$ & 1.20 & Peak $\sim 6.5$ \\
\hline 35 & With thiosulfate, $\mathrm{pH} 5$ & 5.0 & 5.0 & 100 & $1 \mathrm{mM} \mathrm{Na}_{2} \mathrm{~S}_{2} \mathrm{O}_{3}$ & 0.19 & \\
\hline
\end{tabular}




\begin{tabular}{|c|c|c|c|c|c|c|c|}
\hline \multirow{2}{*}{$\begin{array}{l}\text { Run } \\
\text { Number }\end{array}$} & \multirow[b]{2}{*}{ Brief Description } & \multicolumn{3}{|c|}{ Target Conditions } & \multirow[b]{2}{*}{ Additive } & \multirow{2}{*}{$\begin{array}{l}\mathrm{Hg}^{0} \mathrm{Re}- \\
\mathrm{emitted} \\
\left(\mu \mathrm{gg} / \mathrm{Nm}^{3}\right)\end{array}$} & \multirow[b]{2}{*}{ Notes, Issues } \\
\hline & & pH & $(\mathrm{mM})$ & $(\mathrm{mM})$ & & & \\
\hline 36 & With thiosulfate, $\mathrm{pH} 4$ & 4.0 & 5.0 & 100 & $1 \mathrm{mM} \mathrm{Na}_{2} \mathrm{~S}_{2} \mathrm{O}_{3}$ & 0.22 & \\
\hline 37 & With thiosulfate, $\mathrm{pH} 6$ & 6.0 & 5.0 & 100 & $1 \mathrm{mM} \mathrm{Na}_{2} \mathrm{~S}_{2} \mathrm{O}_{3}$ & 1.59 & \\
\hline 38 & $\begin{array}{l}\text { With TMT + Mg(OH)2 } \\
+\mathrm{HClO} 4\end{array}$ & 5.0 & 5.0 & 100 & 0.05 mM TMT & $\begin{array}{l}3.7 \text { after } \\
\text { peak }\end{array}$ & $\begin{array}{l}\text { Emisions slowly } \\
\text { decreasing, } \sim 1.5 \text { at } \\
\text { end }\end{array}$ \\
\hline 39 & $\begin{array}{l}\text { Repeat } 1 \mathrm{mM} \text { sulfite } \\
\text { at } \mathrm{pH} 5\end{array}$ & 5.0 & 1.0 & 100 & None & 6.13 & \\
\hline 40 & $\begin{array}{l}1 \mathrm{mM} \text { sulfite at } \mathrm{pH} \\
7.0\end{array}$ & 7.0 & 1.0 & 100 & None & 2.30 & $\begin{array}{l}\text { Subtracted } 0.9 \text { for } \\
\text { residual } \mathrm{Hg}^{\circ} \text { in outlet } \\
\text { gas }\end{array}$ \\
\hline 41 & $\begin{array}{l}1 \mathrm{mM} \text { sulfite at } \mathrm{pH} \\
4.0\end{array}$ & 4.0 & 1.0 & 100 & None & 5.06 & \\
\hline 42 & $1 \mathrm{mM}$ sulfite at $\mathrm{pH} 6.0$ & 6.0 & 1.0 & 100 & None & 1.47 & $\begin{array}{l}\text { Outlet spike corrected } \\
2.70 \text { without correction }\end{array}$ \\
\hline 43 & $\begin{array}{l}\text { Base case with } 10 \\
\text { mM acetate }\end{array}$ & 5.0 & 5.0 & 100 & $10 \mathrm{mM}$ acetate & 3.28 & \\
\hline 44 & Base case at $50^{\circ} \mathrm{C}$ & 5.0 & 5.0 & 100 & $50^{\circ} \mathrm{C}$ & 1.42 & Very steady run \\
\hline 45 & $20 \mathrm{~mm}$ sulfite, $\mathrm{pH} 7.0$ & 7.0 & 20.0 & 100 & None & 0.85 & \\
\hline 46 & $\begin{array}{l}250 \text { mM chloride; } \\
\text { repeated in Run } 51\end{array}$ & 5.0 & 20.0 & 250 & None & $1.25 \ldots 3.5$ & $\begin{array}{l}1.25 \text { the first hour then } \\
\text { went up to } \sim 4\end{array}$ \\
\hline 47 & $10 \mathrm{mM}$ chloride & 5.0 & 20.0 & 10 & None & 1.72 & $\begin{array}{l}\text { With outlet } \mathrm{Hg}^{\circ} \\
\text { residual correction } \\
\text { applied }\end{array}$ \\
\hline 48 & $\mathrm{pH} 8.0,20 \mathrm{mM}$ sulfite & 8.0 & 20.0 & 100 & None & 0.72 & $\begin{array}{l}\text { Corrected outlet using } \\
\text { FG spike values }\end{array}$ \\
\hline 49 & pH 8.0; 5 mM sulfite & 8.0 & 5.0 & 100 & None & 0.98 & $\begin{array}{l}\text { Corrected outlet using } \\
\text { FG spike values }\end{array}$ \\
\hline 50 & pH 8.0; 1 mM sulfite & 8.0 & 1.0 & 100 & None & 3.24 & Stopping at $15: 30$ \\
\hline 51 & $\begin{array}{l}250 \text { mM Cl, pH 5, } 20 \\
\text { mM sulfite; repeat } \\
\text { Run } 46\end{array}$ & 5.0 & 20.0 & 250 & None & 2.08 & \\
\hline 52 & $\begin{array}{l}15 \mathrm{mM} \mathrm{Ca}^{+2} ; \text { base } \\
\text { case }\end{array}$ & 5.0 & 5.0 & 100 & $15 \mathrm{mM} \mathrm{Ca}^{+2}$ & 4.39 & Initial spike to almost 8 \\
\hline 53 & $15 \mathrm{mM} \mathrm{Ca}^{+2} ; \mathrm{pH} 7$ & 7.0 & 5.0 & 100 & $15 \mathrm{mM} \mathrm{Ca}^{+2}$ & 2.50 & Had an initial spike to \\
\hline
\end{tabular}




\begin{tabular}{|c|c|c|c|c|c|c|c|}
\hline \multirow[b]{2}{*}{$\begin{array}{l}\text { Run } \\
\text { Number }\end{array}$} & \multirow[b]{2}{*}{ Brief Description } & \multicolumn{3}{|c|}{ Target Conditions } & \multirow[b]{2}{*}{ Additive } & \multirow{2}{*}{$\begin{array}{l}\mathrm{Hg}^{0} \mathrm{Re}- \\
\mathrm{emitted} \\
\left(\mu \mathrm{g} / \mathrm{Nm}^{3}\right)\end{array}$} & \multirow[b]{2}{*}{ Notes, Issues } \\
\hline & & pH & $\begin{array}{l}\text { Sulfite } \\
(\mathrm{mM})\end{array}$ & $\begin{array}{l}\text { Chloride } \\
(\mathrm{mM})\end{array}$ & & & \\
\hline & & & & & & & 14 \\
\hline 54 & $\begin{array}{l}\mathrm{pH} 5.0,5 \mathrm{mM} \text { sulfite, } \\
\text { repeat run } 1\end{array}$ & 5.0 & 5.0 & 100 & None & 2.16 & \\
\hline 55 & $\begin{array}{l}\mathrm{pH} \mathrm{5,1} \mathrm{mM} \text { sulfite, } \\
15 \mathrm{mM} \mathrm{Ca}^{+2}\end{array}$ & 5.0 & 1.0 & 100 & $15 \mathrm{mM} \mathrm{Ca}^{+2}$ & 3.54 & \\
\hline 56 & $\begin{array}{l}\mathrm{pH} \mathrm{4,} 1 \mathrm{mM}^{+} \text {sulfite, } \\
15 \mathrm{mM} \mathrm{Ca}^{+2}\end{array}$ & 4.0 & 1.0 & 100 & $15 \mathrm{mM} \mathrm{Ca}^{+2}$ & 5.91 & Corrected output \\
\hline 57 & $\begin{array}{l}\mathrm{pH} \mathrm{6,1} \mathrm{mM}^{2} \text { sulfite, } \\
15 \mathrm{mM} \mathrm{Ca}^{+2}\end{array}$ & 6.0 & 1.0 & 100 & $15 \mathrm{mM} \mathrm{Ca}^{+2}$ & 3.93 & $\begin{array}{l}6.40 \text { before correcting } \\
\text { outlet conc }\end{array}$ \\
\hline 58 & $\begin{array}{l}\mathrm{pH} 8,1 \mathrm{mM}^{2} \text { sulfite, } \\
15 \mathrm{mM} \mathrm{Ca}^{+2}\end{array}$ & 8.0 & 1.0 & 100 & $15 \mathrm{mM} \mathrm{Ca}^{+2}$ & 4.13 & $\begin{array}{l}\text { Going to redo this one } \\
\text { (high spikes on inlet) }\end{array}$ \\
\hline 59 & $\begin{array}{l}\text { Low absorber volume } \\
\text { (3.0"); base case }\end{array}$ & 5.0 & 5.0 & 100 & None & 4.71 & $\begin{array}{l}1100 p^{p m ~ S O} \mathrm{~S}_{2} \text { in, } 475 \\
\text { out }\end{array}$ \\
\hline 60 & $\begin{array}{l}\text { High absorber } \\
\text { volume (9.5"); base } \\
\text { case }\end{array}$ & 5.0 & 5.0 & 100 & None & 1.55 & $\begin{array}{l}1150 \mathrm{ppm} \mathrm{SO}_{2} \text { in, } 124 \\
\text { out }\end{array}$ \\
\hline 61 & $\begin{array}{l}10 \mathrm{mM} \mathrm{Ca}^{+2} ; \text { base } \\
\text { case }\end{array}$ & 5.0 & 5.0 & 100 & $10 \mathrm{mM} \mathrm{Ca}^{+2}$ & -0.40 & Inlet is high and erratic \\
\hline 62 & $\begin{array}{l}5 \mathrm{mM} \mathrm{Ca}^{+2} ; \text { base } \\
\text { case }\end{array}$ & 5.0 & 5.0 & 100 & $5 \mathrm{mM} \mathrm{Ca}^{+2}$ & 1.24 & \\
\hline 63 & Repeat Run 58 & 8.0 & 1.0 & 100 & $15 \mathrm{mM} \mathrm{Ca}^{+2}$ & 8.32 & $\begin{array}{l}\text { Odd run - increased } \\
\text { sulfite at } 15: 00 \text { and } \\
\text { outlet went way up } \\
\text { again; ORP very high; } \\
\text { avg sulfite was } 0.86 \\
\text { mM }\end{array}$ \\
\hline 64 & $\begin{array}{l}15 \mathrm{mM} \mathrm{Ca}^{+2}+200 \\
\mathrm{mM} \mathrm{Mg}^{+2} ; \text { base case }\end{array}$ & 5.0 & 5.0 & 100 & $\begin{array}{l}15 \mathrm{mM} \mathrm{Ca}^{+2}+ \\
200 \mathrm{mM} \mathrm{Mg}^{+2}\end{array}$ & 2.24 & \\
\hline 65 & Base case at $45^{\circ} \mathrm{C}$ & 5.0 & 5.0 & 100 & $45^{\circ} \mathrm{C}$ & 0.62 & $\begin{array}{l}\text { It probably should be } \\
\text { lower than 0.62; took } \\
\text { long time for outlet } \\
\text { response to come } \\
\text { down from cal check } \\
\text { spike }\end{array}$ \\
\hline 66 & $\begin{array}{l}\text { Base case without } \\
\mathrm{HCl} \text { in gas }\end{array}$ & 5.0 & 5.0 & 100 & $\mathrm{No} \mathrm{HCl}$ in gas & 1.68 & $\begin{array}{l}\text { May be lower; near } \\
\text { end, outlet going down } \\
\text { and inlet up }\end{array}$ \\
\hline 67 & Repeat base case & 5.0 & 5.0 & 100 & None & 2.84 & Smooth run \\
\hline
\end{tabular}




\begin{tabular}{|c|c|c|c|c|c|c|c|}
\hline \multirow[b]{2}{*}{$\begin{array}{l}\text { Run } \\
\text { Number }\end{array}$} & \multirow[b]{2}{*}{ Brief Description } & \multicolumn{3}{|c|}{ Target Conditions } & \multirow[b]{2}{*}{ Additive } & \multirow{2}{*}{$\begin{array}{l}\mathrm{Hg}^{0} \mathrm{Re}- \\
\mathrm{emitted} \\
\left(\mu \mathrm{g} / \mathrm{Nm}^{3}\right)\end{array}$} & \multirow[b]{2}{*}{ Notes, Issues } \\
\hline & & pH & $\begin{array}{l}\text { Sulfite } \\
(\mathrm{mM})\end{array}$ & $\begin{array}{l}\text { Chloride } \\
(\mathrm{mM})\end{array}$ & & & \\
\hline 68 & Glycolic acid effect & 5.0 & 5.0 & 100 & $\begin{array}{l}3 \mathrm{mM} \text { glycolic } \\
\text { acid }\end{array}$ & 14.20 & $\begin{array}{l}\text { Outlet Hg erratic but } \\
\text { stable average value }\end{array}$ \\
\hline 69 & TMT with $\mathrm{Ca}^{+2}$ & 5.0 & 5.0 & 100 & $\begin{array}{l}0.05 \mathrm{mM} \mathrm{TMT}^{+} \\
15 \mathrm{mM} \mathrm{Ca}^{+2}\end{array}$ & 0.00 & $\begin{array}{l}\text { Initial spike to } 13 \text { but } \\
\text { very low after } \sim 1 \text { hour }\end{array}$ \\
\hline 70 & Low TMT with $\mathrm{Ca}^{+2}$ & 5.0 & 5.0 & 100 & $\begin{array}{l}0.005 \mathrm{mM} \mathrm{TMT}^{+} \\
15 \mathrm{mM} \mathrm{Ca}^{+2}\end{array}$ & 1.49 & $\begin{array}{l}\text { Lots of problems - low } \\
\text { liquor volume }\end{array}$ \\
\hline 71 & Nitrite in base case & 7.0 & 5.0 & 100 & $1 \mathrm{mM} \mathrm{NaNO}_{2}$ & 1.14 & $\begin{array}{l}\text { Re-emits } \sim 1.5 \text { at first, } \\
\text { gradually decreases }\end{array}$ \\
\hline 72 & Thiosulfate at $\mathrm{pH} 7.0$ & 7.0 & 5.0 & 100 & $1 \mathrm{mM} \mathrm{Na}_{2} \mathrm{~S}_{2} \mathrm{O}_{3}$ & 2.40 & $\begin{array}{l}\text { After } \mathrm{Hg}^{+2} \text { finally } \\
\text { injected at end of run }\end{array}$ \\
\hline 73 & $\begin{array}{l}\text { Repeat thiosulfate at } \\
\mathrm{pH} 7.0\end{array}$ & 7.0 & 5.0 & 100 & 1-2 $\mathrm{mM} \mathrm{Na}_{2} \mathrm{~S}_{2} \mathrm{O}_{3}$ & 2.47 & $\begin{array}{l}\text { At end of run after } 2 \text { nd } \\
\text { dose of } \mathrm{Na}_{2} \mathrm{~S}_{2} \mathrm{O}_{3}\end{array}$ \\
\hline 74 & $\begin{array}{l}\text { Repeat pH } 7.0 \text { base } \\
\text { case }\end{array}$ & 7.0 & 5.0 & 100 & None & 0.45 & $\begin{array}{l}\text { Some sulfite analytical } \\
\text { problems; ORP spikes } \\
\text { downward }\end{array}$ \\
\hline 75 & Adipic acid $+\mathrm{Ca}^{+2}$ & 5.0 & 5.0 & 100 & $\begin{array}{l}15 \mathrm{mM} \mathrm{Ca}^{+2}+ \\
3.4 \mathrm{mM} \text { adipic } \\
\text { acid }\end{array}$ & 7.14 & $\begin{array}{l}\text { Higher than either } \\
\mathrm{Ca}^{+2} \text { or adipic alone; } \\
\text { used last } 2 \text { hours; } \\
\text { sulfite control } \\
\text { problems at first }\end{array}$ \\
\hline 76 & $\begin{array}{l}\text { Thiosulfate (from } \\
\text { solid reagent) at } \mathrm{pH} \\
7.0\end{array}$ & 7.0 & 5.0 & 100 & $1 \mathrm{mM} \mathrm{Na} 2 \mathrm{~S}_{2} \mathrm{O}_{3}$ & 2.22 & $\begin{array}{l}\text { Initial spike to } \sim 20 \text { and } \\
\text { took a while to fall }\end{array}$ \\
\hline 77 & $\begin{array}{l}\mathrm{Ca}^{+2} \text { with } \mathrm{Na} \\
\text { diethyldithio- } \\
\text { carbamate }\end{array}$ & 5.0 & 5.0 & 100 & $\begin{array}{l}15 \mathrm{mM} \mathrm{Ca}+2+ \\
0.15 \mathrm{mM} \text { DEDTC }\end{array}$ & 1.61 & $\begin{array}{l}\text { Emissions higher first } \\
45 \text { min; avg } 1.9 \text { if use } \\
\text { that }\end{array}$ \\
\hline 78 & With $\mathrm{NO}_{\mathrm{x}}$ and $\mathrm{Ca}^{+2}$ & 5.0 & 5.0 & 100 & $\begin{array}{l}15 \mathrm{mM} \mathrm{Ca}^{+2} \text { with } \\
260 \mathrm{ppm} \mathrm{NO}^{2}+15 \\
\text { ppm NO}\end{array}$ & 2.00 & Quite steady \\
\hline 79 & Thiosulfate with $\mathrm{Ca}^{+2}$ & 5.0 & 5.0 & 100 & $\begin{array}{l}15 \mathrm{mM} \mathrm{Ca}^{+2}+1 \\
\mathrm{mM} \mathrm{Na}_{2} \mathrm{~S}_{2} \mathrm{O}_{3}\end{array}$ & 0.02 & \\
\hline 81 & Base case at $45{ }^{\circ} \mathrm{C}$ & 5.0 & 5.0 & 100 & $45^{\circ} \mathrm{C}$ & -0.10 & $\begin{array}{l}\text { Data logger not } \\
\text { running }\end{array}$ \\
\hline 83 & $\begin{array}{l}\text { Base case, start with } \\
\text { no } \mathrm{H}_{2} \mathrm{O} \text { to check } \mathrm{HCl} \\
\text { measurement }\end{array}$ & 5.0 & 5.0 & 100 & None & 1.74 & Smooth run \\
\hline 84 & $\begin{array}{l}\text { Base case without } \\
\text { chloride }\end{array}$ & 5.0 & 5.0 & 0 & None & 2.30 & $\begin{array}{l}\text { Outlet slowly } \\
\text { decreasing during run; } \\
\text { initial value } \sim 2.7 \text { for } 1 \\
\text { hr; compare run } 22\end{array}$ \\
\hline
\end{tabular}




\begin{tabular}{|c|c|c|c|c|c|c|c|}
\hline \multirow[b]{2}{*}{\begin{tabular}{|l} 
Run \\
Number
\end{tabular}} & \multirow[b]{2}{*}{ Brief Description } & \multicolumn{3}{|c|}{ Target Conditions } & \multirow[b]{2}{*}{ Additive } & \multirow{2}{*}{$\begin{array}{l}\mathrm{Hg}^{0} \mathrm{Re}- \\
\mathrm{emitted} \\
\left(\mu \mathrm{g} / \mathrm{Nm}^{3}\right)\end{array}$} & \multirow[b]{2}{*}{ Notes, Issues } \\
\hline & & pH & \begin{tabular}{|l} 
Sulfite \\
$(\mathrm{mM})$
\end{tabular} & $\begin{array}{l}\text { Chloride } \\
(\mathrm{mM})\end{array}$ & & & \\
\hline 85 & $\begin{array}{l}\mathrm{Ca}^{+2} \text { with lower } \mathrm{Na} \\
\text { diethyldithio- } \\
\text { carbamate }\end{array}$ & 5.0 & 5.0 & 100 & $\begin{array}{l}15 \mathrm{mM} \mathrm{Ca}^{+2}+ \\
0.022 \mathrm{mM} \\
\text { DEDTC }\end{array}$ & 1.10 & $\begin{array}{l}\text { Slightly higher right } \\
\text { after injection }\end{array}$ \\
\hline 86 & $\begin{array}{l}\text { Thiosulfate with } \mathrm{Ca}^{+2} \\
\text { at high } \mathrm{pH}\end{array}$ & 7.0 & 5.0 & 100 & $\begin{array}{l}15 \mathrm{mM} \mathrm{Ca}^{+2}+1 \\
\mathrm{mM} \mathrm{Na}_{2} \mathrm{~S}_{2} \mathrm{O}_{3}\end{array}$ & 0.69 & $\begin{array}{l}\text { Very erratic run; sulfite } \\
\text { erratic too }\end{array}$ \\
\hline 87 & $\begin{array}{l}\text { Repeat pH 8, } 1 \text { mM } \\
\text { sulfite (run 50) }\end{array}$ & 8.0 & 1.0 & 100 & None & 6.95 & \\
\hline 88 & $\begin{array}{l}\text { Base case with } \\
\text { HADS (made fresh) }\end{array}$ & 5.0 & 5.0 & 100 & $5 \mathrm{mM}$ HADS & 2.84 & \\
\hline 89 & Thiosulfate at $\mathrm{pH} 8$ & 8.0 & 5.0 & 100 & $1 \mathrm{mM} \mathrm{Na}_{2} \mathrm{~S}_{2} \mathrm{O}_{3}$ & 4.39 & \\
\hline 90 & $\begin{array}{l}\text { Base case with } \\
\text { HADS }\end{array}$ & 5.0 & 5.0 & 100 & $3.5 \mathrm{mM}$ HADS & 4.31 & $\begin{array}{l}\text { Slowly decreased to } \\
\text { this value; } 4.9 \text { if use } \\
\text { earlier results }\end{array}$ \\
\hline 91 & Base case & 5.0 & 5.0 & 100 & $\mathrm{Hg}^{+2}$; excess & 4.10 & $\begin{array}{l}\text { Slowly decreasing; } \\
\text { corrected for injecting } \\
\text { too much } \mathrm{Hg}+2\end{array}$ \\
\hline 92 & $\begin{array}{l}\mathrm{pH} 4.0,5 \mathrm{mM} \text { sulfite, } \\
\text { no chloride }\end{array}$ & 4.0 & 5.0 & 0 & $\begin{array}{l}\text { No } \mathrm{HCl} \text { in gas } \\
\text { either }\end{array}$ & 27.3 & $\begin{array}{l}\text { Steadily decreasing } \\
\text { from } \sim 35 \text { to } 22\end{array}$ \\
\hline 93 & Base case & 5.0 & 5.0 & 100 & & 1.91 & $\begin{array}{l}\text { Analyzers moving } \\
\text { around, emission } \\
\text { decreased last half of } \\
\text { run }\end{array}$ \\
\hline 94 & $\begin{array}{l}\text { No chloride, } \mathrm{pH}^{+} 4.0 \\
\text { with } 15 \mathrm{mM} \mathrm{Ca}^{+2}\end{array}$ & 4.0 & 5.0 & 0 & $\mathrm{Ca}^{+2} ; 15 \mathrm{mM}$ & 23.40 & $\begin{array}{l}\text { Decreased steadily } \\
\text { from } 31 \text { to } \sim 20 \text { over } \\
3.5 \text { hours }\end{array}$ \\
\hline 95 & $\begin{array}{l}\mathrm{pH} 8 \text { with } 2 \mathrm{mM} \\
\text { sulfite }\end{array}$ & 8.0 & 2.0 & 100 & none & 6.36 & \\
\hline 96 & $\begin{array}{l}\text { Repeat Run } 61,10 \\
\mathrm{mM} \mathrm{Ca}^{+2}\end{array}$ & 5.0 & 5.0 & 100 & $\mathrm{Ca}^{+2} ; 10 \mathrm{mM}$ & 3.10 & $\begin{array}{l}\text { This is for } 1 \text { st } 2 \text { hrs; } \\
\text { then inlet went high; e } \\
\text { for whole run about } \\
2.4\end{array}$ \\
\hline 97 & $\begin{array}{l}\text { Repeat Run 62, } 5 \\
\mathrm{mM} \mathrm{Ca}^{+2}\end{array}$ & 5.0 & 5.0 & 100 & $\mathrm{Ca}^{+2} ; 5 \mathrm{mM}$ & 3.30 & $\begin{array}{l}\text { Avg for } 5 \mathrm{hr} \text { while } \\
\text { slowly decreased }\end{array}$ \\
\hline 98 & $\begin{array}{l}\mathrm{pH} 8.0,5 \text { mM sulfite; } \\
\text { repeat Run } 49\end{array}$ & 8.0 & 5.0 & 100 & none & 5.40 & Steady \\
\hline 99 & Base case & 5.0 & 5.0 & 100 & none & 3.12 & $\begin{array}{l}\text { Slow downward trend } \\
\text { but nice run; Data } \\
\text { logger avg pH 4.84; } \\
\text { assume abs pH } 0.07 \\
\text { lower }\end{array}$ \\
\hline
\end{tabular}




\begin{tabular}{|c|c|c|c|c|c|c|c|}
\hline \multirow{2}{*}{$\begin{array}{l}\text { Run } \\
\text { Number }\end{array}$} & \multirow[b]{2}{*}{ Brief Description } & \multicolumn{3}{|c|}{ Target Conditions } & \multirow[b]{2}{*}{ Additive } & \multirow{2}{*}{$\begin{array}{l}\mathrm{Hg}^{0} \mathrm{Re}- \\
\mathrm{emitted} \\
\left(\mu \mathrm{g} / \mathrm{Nm}^{3}\right)\end{array}$} & \multirow[b]{2}{*}{ Notes, Issues } \\
\hline & & pH & $\begin{array}{l}\text { Sulrite } \\
(\mathrm{mM})\end{array}$ & $\begin{array}{l}\text { Chloride } \\
\text { (mM) }\end{array}$ & & & \\
\hline 100 & Nalmet 8034 & 5.0 & 5.0 & 100 & $\begin{array}{l}\text { Nalmet 8034; } \\
0.05 \mathrm{mM}\end{array}$ & 0.01 & $\begin{array}{l}\text { This is for about } 3 \\
\text { hours after a very } \\
\text { large (53) initial spike - } \\
\text { decayed in } \sim 1 \text { hour }\end{array}$ \\
\hline 101 & $\begin{array}{l}\text { Base case (several } \\
\text { prev. days aborted } \\
\text { due to high outlet } \mathrm{Hg} \text {, } \\
\text { contam. from } \\
\text { Nalmet?) }\end{array}$ & 5.0 & 5.0 & 100 & None & 2.47 & Steady \\
\hline 102 & $\mathrm{pH}$ 6, $15 \mathrm{mM} \mathrm{Ca}^{+2}$ & 6.0 & 5.0 & 100 & $\mathrm{Ca}^{+2} ; 15 \mathrm{mM}$ & 2.23 & $\begin{array}{l}\text { Nearly } 5.5 \mathrm{cc} \mathrm{Hg}^{+2} \\
\text { slight decline }\end{array}$ \\
\hline 103 & $\begin{array}{l}\mathrm{pH} 5,1 \mathrm{mM}^{+2} \text { sulfite, } \\
15 \mathrm{mM} \mathrm{Ca}^{2}\end{array}$ & 5.0 & 1.0 & 100 & $\mathrm{Ca}^{+2} ; 10 \mathrm{mM}$ & 4.54 & $\begin{array}{l}\text { A sulfite spike made } \\
\text { this a little lower than } \\
\text { would have been }\end{array}$ \\
\hline 104 & $\begin{array}{l}\mathrm{pH} \mathrm{5,} 1 \mathrm{mM} \text { sulfite, } 5 \\
\mathrm{mM} \mathrm{Ca}^{+2}\end{array}$ & 5.0 & 1.0 & 100 & $\mathrm{Ca}^{+2} ; 5 \mathrm{mM}$ & 4.66 & \\
\hline 105 & $\begin{array}{l}\mathrm{pH} \mathrm{4,} 1 \mathrm{mM} \text { sulfite, } 5 \\
\mathrm{mM} \mathrm{Ca}^{+2}\end{array}$ & 4.0 & 1.0 & 100 & $\mathrm{Ca}^{+2} ; 5 \mathrm{mM}$ & 6.28 & $\begin{array}{l}\text { Seemed to drop after } \\
\text { calibration injection }\end{array}$ \\
\hline 106 & $\begin{array}{l}\mathrm{pH} \mathrm{6,1} \text { mM sulfite, } 5 \\
\mathrm{mM} \mathrm{Ca}^{+2}\end{array}$ & 6.0 & 1.0 & 100 & $\mathrm{Ca}^{+2} ; 5 \mathrm{mM}$ & 3.12 & \\
\hline 107 & Base case & 5.0 & 5.0 & 100 & None & 2.74 & pH high \\
\hline 108 & $\begin{array}{l}\mathrm{pH} 4.0,5 \mathrm{mM} \text { sulfite, } \\
15 \mathrm{mM} \mathrm{Ca}^{+2}\end{array}$ & 4.0 & 5.0 & 100 & $\mathrm{Ca}^{+2} ; 15 \mathrm{mM}$ & 4.92 & $\begin{array}{l}\text { Does not use last hour } \\
\text { or so where } \mathrm{Hg} \\
\text { decreased a lot at } \\
\text { same time measured } \\
\text { sulfite dropped to } 0\end{array}$ \\
\hline 109 & $\begin{array}{l}\mathrm{pH} \text { 4.0, } 20 \mathrm{mM} \\
\text { sulfite, } 15 \mathrm{mM} \mathrm{Ca}\end{array}$ & 4.0 & 20.0 & 100 & $\mathrm{Ca}^{+2} ; 15 \mathrm{mM}$ & 6.08 & $\begin{array}{l}\text { Slowly decreases from } \\
\text { initial of about } 8\end{array}$ \\
\hline 110 & $\begin{array}{l}\text { pH 5.0, } 20 \mathrm{mM} \\
\text { sulfite, } 15 \mathrm{mM} \mathrm{Ca}\end{array}$ & 5.0 & 20.0 & 100 & $\mathrm{Ca}^{+2} ; 15 \mathrm{mM}$ & 2.53 & $\begin{array}{l}\text { Two brief spikes of } \\
\text { higher emissions when } \\
\text { sulfite went low }\end{array}$ \\
\hline 111 & $\begin{array}{l}\mathrm{pH} \text { 6.0, } 20 \mathrm{mM} \\
\text { sulfite, } 15 \mathrm{mM} \mathrm{Ca}\end{array}$ & 6.0 & 20.0 & 100 & $\mathrm{Ca}^{+2} ; 15 \mathrm{mM}$ & 1.90 & \\
\hline 112 & $\begin{array}{l}\text { Base case after long } \\
\text { time off }\end{array}$ & 5.0 & 5.0 & 100 & none & 2.20 & \\
\hline 113 & Repeat base case & 5.0 & 5.0 & 100 & none & 1.65 & $\begin{array}{l}\text { Inlet looks a little high; } \\
\text { gold column may have } \\
\text { needed changing }\end{array}$ \\
\hline 114 & Base case & 5.0 & 5.0 & 100 & none & {$[0.90]$} & $\begin{array}{l}\text { Not a good run; sulfite } \\
\text { varies and liquor }\end{array}$ \\
\hline
\end{tabular}




\begin{tabular}{|c|c|c|c|c|c|c|c|}
\hline \multirow{2}{*}{$\begin{array}{l}\text { Run } \\
\text { Number }\end{array}$} & \multirow[b]{2}{*}{ Brief Description } & \multicolumn{3}{|c|}{ Target Conditions } & \multirow[b]{2}{*}{ Additive } & \multirow{2}{*}{$\begin{array}{l}\mathrm{Hg}^{0} \mathrm{Re}- \\
\mathrm{emitted} \\
\left(\mu \mathrm{g} / \mathrm{Nm}^{3}\right)\end{array}$} & \multirow[b]{2}{*}{ Notes, Issues } \\
\hline & & $\mathrm{pH}$ & $(\mathrm{mM})$ & $(\mathrm{mM})$ & & & \\
\hline & & & & & & & volume mystery \\
\hline 117 & $\begin{array}{l}0.066 \text { mM L-cysteine; } \\
\text { base case }\end{array}$ & 5.0 & 5.0 & 100 & $\begin{array}{l}\text { cysteine, L; } 0.066 \\
\text { mM }\end{array}$ & 4.11 & $\begin{array}{l}\text { Fairly smooth run; inlet } \\
\text { slowly increasing }\end{array}$ \\
\hline 119 & $\begin{array}{l}\text { Base case after } \\
\text { replacing lines }\end{array}$ & 5.0 & 5.0 & 100 & none & 1.10 & Temperature low \\
\hline 120 & $\begin{array}{l}\text { Base case with temp } \\
\text { back to } 55^{\circ} \mathrm{C}\end{array}$ & 5.0 & 5.0 & 100 & none & 2.10 & \\
\hline 121 & Low inlet $\mathrm{SO}_{2}$ & 5.0 & 5.0 & 100 & none & 1.68 & Absorber pH high \\
\hline 122 & $\begin{array}{l}\text { High inlet } \mathrm{SO}_{2}, 2000 \\
\text { ppm }\end{array}$ & 5.0 & 5.0 & 100 & none & 1.36 & \\
\hline 123 & $3 \mathrm{~L}$ reactor volume & 5.0 & 5.0 & 100 & none & 1.26 & $\begin{array}{l}\text { Inlet went high for } \\
\text { some reason else } \\
\text { would be closer to } 2\end{array}$ \\
\hline 128 & $\begin{array}{l}\text { Base case after fixing } \\
\text { rusty fitting problem }\end{array}$ & 5.0 & 5.0 & 100 & none & 2.45 & Nice run \\
\hline 129 & $0.2 \mathrm{mM}$ sulfite, $\mathrm{pH} 5$ & 5.0 & 0.2 & 100 & $\begin{array}{l}\text { meas avg sulfite } \\
0.24 \mathrm{mM}\end{array}$ & 11.6 & No inlet mercury \\
\hline 130 & $0.2 \mathrm{mM}$ sulfite, $\mathrm{pH} 4$ & 4.0 & 0.2 & 100 & $\begin{array}{l}\text { meas avg sulfite } \\
0.22 \mathrm{mM}\end{array}$ & 4.96 & \\
\hline 131 & $0.2 \mathrm{mM}$ sulfite, $\mathrm{pH} 6$ & 6.0 & 0.2 & 100 & $\begin{array}{l}\text { meas avg sulfite } \\
0.23 \mathrm{mM}\end{array}$ & 10.3 & $\begin{array}{l}\text { Use abs } \mathrm{pH} \text { from data } \\
\text { logger file; assume } 5.0 \\
\mathrm{~g} \mathrm{Hg}^{+2} \text { soln added }\end{array}$ \\
\hline 132 & $\begin{array}{l}0.2 \text { mM sulfite, pH 5; } \\
\text { repeat Run } 129\end{array}$ & 5.0 & 0.2 & 100 & $\begin{array}{l}\text { meas avg sulfite } \\
0.22 \mathrm{mM}\end{array}$ & 8.38 & \\
\hline 133 & Base case & 5.0 & 5.0 & 100 & None & 2.60 & \\
\hline 136 & Base case & 5.0 & 5.0 & 100 & None & 2.24 & \\
\hline 137 & $\begin{array}{l}\text { No sulfite or } \mathrm{SO}_{2}, 10 \\
\text { mM sulfate }\end{array}$ & 5.0 & 0.0 & 100 & None & 1.9 to 8.9 & $\begin{array}{l}\text { Started off at about } 2 \\
\text { and then rose and } \\
\text { leveled off at about } 9\end{array}$ \\
\hline 139 & $\begin{array}{l}\text { Base case with extra } \\
\mathrm{Hg}^{0} \text { in gas }\end{array}$ & 5.0 & 5.0 & 100 & None & 1.78 & \\
\hline 140 & $\begin{array}{l}\text { Base case with } 200 \\
\text { mM acetate }\end{array}$ & 5.0 & 5.0 & 100 & Acetate; $\sim 200 \mathrm{mM}$ & 1.10 & $\begin{array}{l}\text { Decreases with time, } \\
\text { starts } \sim 1.5\end{array}$ \\
\hline 141 & $\begin{array}{l}\text { Base case with } 100 \\
\text { mM acetate }\end{array}$ & 5.0 & 5.0 & 100 & Acetate; 100 mM & 1.85 & $\begin{array}{l}\text { Decreases, first hour } \\
\text { avg } 2.20\end{array}$ \\
\hline 142 & $\mathrm{pH} 4.0100 \mathrm{mM}$ & 4.0 & 5.0 & 100 & Acetate; $100 \mathrm{mM}$ & 4.16 & Decreases, first hour \\
\hline
\end{tabular}




\begin{tabular}{|c|c|c|c|c|c|c|c|}
\hline \multirow{2}{*}{$\begin{array}{l}\text { Run } \\
\text { Number }\end{array}$} & \multirow[b]{2}{*}{ Brief Description } & \multicolumn{3}{|c|}{ Target Conditions } & \multirow[b]{2}{*}{ Additive } & \multirow{2}{*}{$\begin{array}{l}\mathrm{Hg}^{0} \mathrm{Re}- \\
\mathrm{emitted} \\
\left(\mu \mathrm{g} / \mathrm{Nm}^{3}\right)\end{array}$} & \multirow[b]{2}{*}{ Notes, Issues } \\
\hline & & pH & $\begin{array}{l}\text { Sultite } \\
\text { (mM) }\end{array}$ & $\mid \begin{array}{l}\text { Chioride } \\
(\mathrm{mM})\end{array}$ & & & \\
\hline & acetate & & & & & & avg is 5.8 \\
\hline 143 & $\begin{array}{l}\mathrm{pH} 6.0,100 \mathrm{mM} \\
\text { acetate }\end{array}$ & 6.0 & 5.0 & 100 & Acetate; 100 mM & 1.30 & Slowly decreases \\
\hline 144 & Base case & 5.0 & 5.0 & 100 & None & 2.14 & Smooth run \\
\hline 145 & $\begin{array}{l}\text { With } 10 \mathrm{mM} \mathrm{Fe}^{+2}, \mathrm{pH} \\
\text { 4.0 }\end{array}$ & 4.0 & 5.0 & 100 & $\mathrm{Fe}(\mathrm{ClO} 4)_{2} ; 10 \mathrm{mM}$ & 3.86 & $\begin{array}{l}\text { Emissions very high } \\
(>60) \text { at start of run; } \\
\text { sulfite control } \\
\text { problems }\end{array}$ \\
\hline 146 & $\begin{array}{l}\text { With } 10 \mathrm{mM} \mathrm{Fe}^{+3}, \mathrm{pH} \\
4.0\end{array}$ & 4.0 & 5.0 & 100 & $\mathrm{FeCl}_{3} ; 10 \mathrm{mM}$ & 4.99 & $\begin{array}{l}\text { Smoother run except } \\
\text { for erratic sulfite (avg } \\
3.7 \mathrm{mM})\end{array}$ \\
\hline 147 & Base case & 5.0 & 5.0 & 100 & none & 2.88 & Nice run \\
\hline 148 & 0.05 mM Pravo 1.1 & 5.0 & 5.0 & 100 & $\begin{array}{l}\text { Pravo 1.1; } 0.05 \\
\text { mM }\end{array}$ & 1.87 & \\
\hline 149 & 0.05 mM Pravo 1.2 & 5.0 & 5.0 & 100 & $\begin{array}{l}\text { Pravo 1.2; } 0.05 \\
\text { mM }\end{array}$ & 1.08 & Nice run \\
\hline 150 & Base case & 5.0 & 5.0 & 100 & None & 2.31 & $\begin{array}{l}\text { Strange prolonged } \\
\text { spike in middle, } \\
\text { eliminated spike from } \\
\text { run file }\end{array}$ \\
\hline 151 & Pravo 1.3 & 5.0 & 5.0 & 100 & $\begin{array}{l}\text { Pravo 1.3; } 0.05 \\
\mathrm{mM}\end{array}$ & 1.38 & \\
\hline 152 & Pravo 0 & 5.0 & 5.0 & 100 & Pravo 0; $0.05 \mathrm{mM}$ & 2.19 & $\begin{array}{l}\text { Slowly increases from } \\
\text { about } 1.5\end{array}$ \\
\hline 153 & Base case & 5.0 & 5.0 & 100 & None & 1.76 & $\begin{array}{l}\text { Only two manual pH } \\
\text { points but } \mathrm{A} / \mathrm{D} \mathrm{pH} \text { also } \\
\text { high; sulfite control } \\
\text { erratic; not a good run }\end{array}$ \\
\hline
\end{tabular}

Since there are far too many variables to do a full study of each, for the initial series of runs an approach was adopted where a "base case" condition of $\mathrm{pH}$ 5.0, $5.0 \mathrm{mM}$ sulfite, $100 \mathrm{mM}$ chloride and $55^{\circ} \mathrm{C}$ was chosen. This condition was repeated periodically, and variable effects were compared to that condition. Results obtained upon introducing other species or conditions were run and compared to the base case result to see if additional study was warranted. If it was, either the parameter was varied or runs were done at different $\mathrm{pH}$ and sulfite conditions, or both. Although this base case condition was a compromise of many varied potential FGD conditions (and did not include calcium, see below), it has provided a starting point for a number of comparisons, as detailed below. The mean value of the base case re-emission $\left(0.5 \mu \mathrm{M} \mathrm{Hg}\left(\mathrm{ClO}_{4}\right)_{2}\right.$ added) is $2.30 \mu \mathrm{g} / \mathrm{Nm}^{3}$ with a standard deviation of $0.52 \mu \mathrm{g} / \mathrm{Nm}^{3}$ for eighteen measurements. 


\section{Sulfite-pH-Chloride Dependence}

One of the initial points of focus has been the sulfite concentration $-\mathrm{pH}-$ chloride dependence of re-emissions. Some preliminary results are shown in Figure 38 and indicate that for the 5-mM and $20-\mathrm{mM}$ sulfite cases the expected trend of rates increasing as $\mathrm{pH}$ is lowered is obtained. The 1- $\mathrm{mM}$ sulfite case has higher re-emission rates than the higher sulfite concentrations at $\mathrm{pH} 5$ and 6 , as expected, but anomalous behavior is seen at $\mathrm{pH} 4$ and perhaps at $\mathrm{pH}$ values above 7 . The model predicts a small maximum in re-emissions for the 1-mM sulfite level between $\mathrm{pH} 3$ and 4 . This particular combination of low $\mathrm{pH}$ and low sulfite is difficult to control and additional testing in that region is planned. There is also an uncertainty as to which $\mathrm{pH}$ to use for comparing experiment and modeling: in our apparatus; the $\mathrm{pH}$ of the absorber is typically 0.3 to $0.4 \mathrm{pH}$ units lower than the $\mathrm{pH}$ of the reaction tank, which is the value which is controlled and reported here.

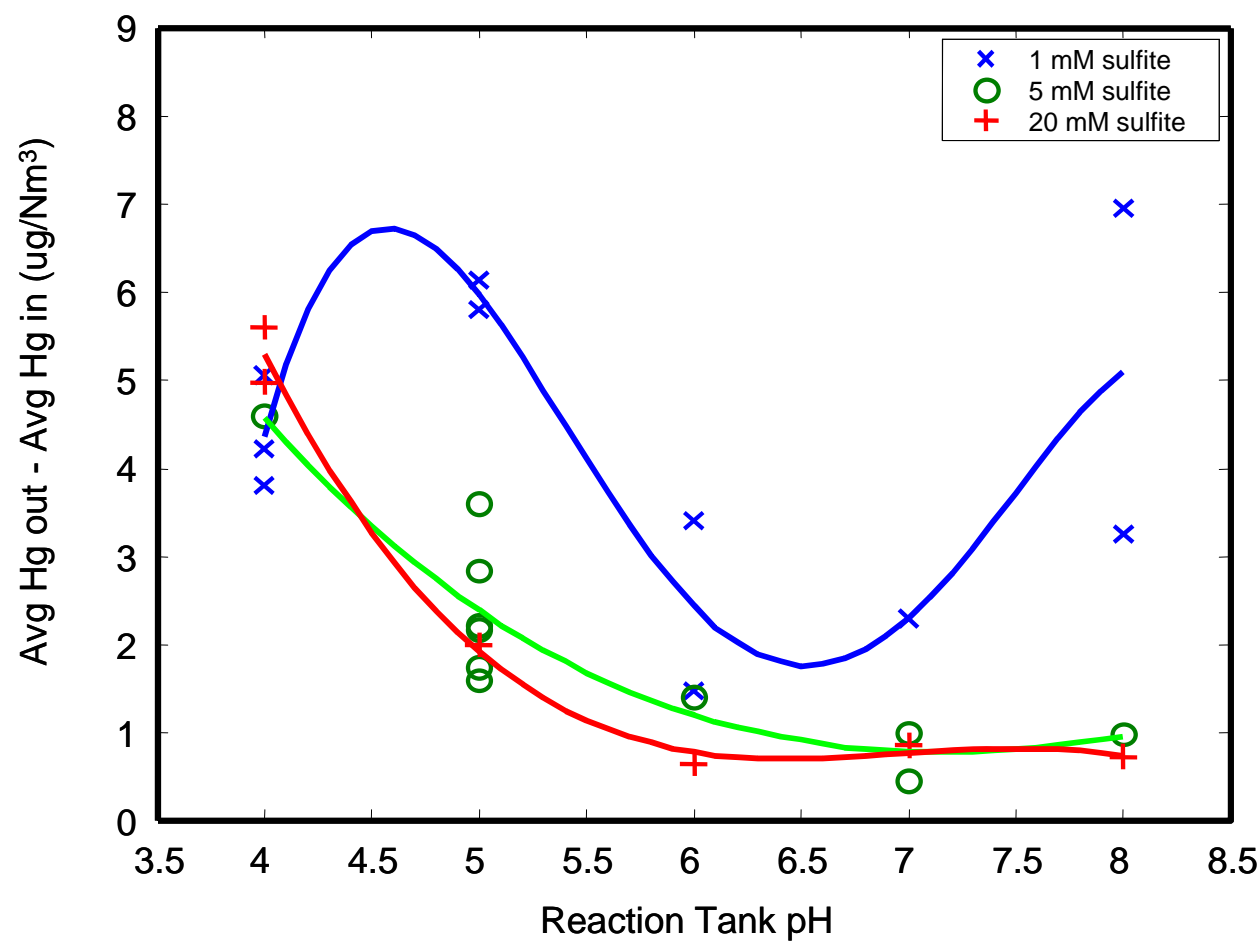

Figure 38. Bench-scale Re-emissions as a Function of pH

Although the general trend is for re-emissions to decrease with increasing $\mathrm{pH}$ in the $\mathrm{pH}$ 4-7 region, these results show that at low sulfite concentration (1-2 mM) the re-emissions can increase rapidly at elevated $\mathrm{pH}(\mathrm{pH} 8.0)$. This effect is smaller and somewhat erratic at sulfite values of $5 \mathrm{mM}$, and is not seen at $20 \mathrm{mM}$ sulfite.

The effects of very low sulfite values are of interest since such conditions exist in forced oxidation FGD systems and since lower sulfites are expected to give higher re-emissions. Several runs were made with $0.2 \mathrm{mM}$ sulfite (which is as low as could be detected and controlled with the present equipment) and at three $\mathrm{pH}$ values. Results are shown below in Figure 39. 


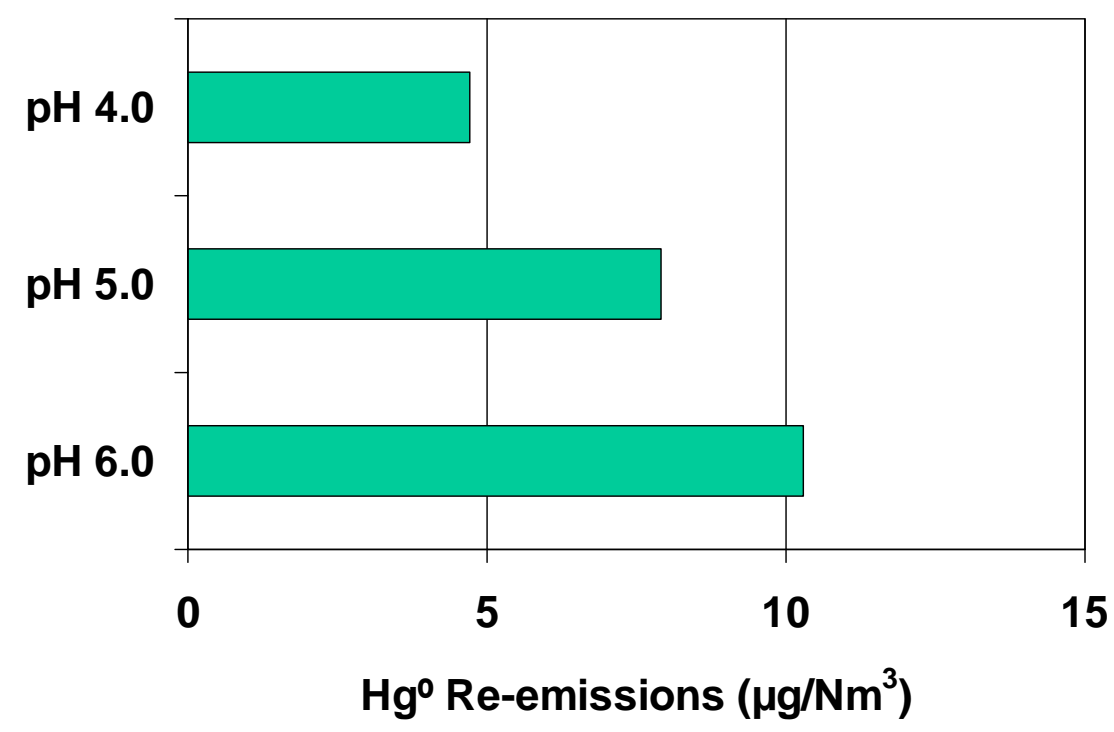

Figure 39. Effect of pH on Re-emissions at $0.2 \mathrm{mM}$ Sulfite, $100 \mathrm{mM}$ Chloride

In contrast to what we observed at higher sulfite concentrations, the re-emissions increase somewhat dramatically with increasing $\mathrm{pH}$. This is illustrated in Figure 40 by overlaying the data from Figure 40 on the previous data plot from Figure 38. This same trend with $\mathrm{pH}$ is predicted by the kinetics model, but it does not predict increases as large as observed.

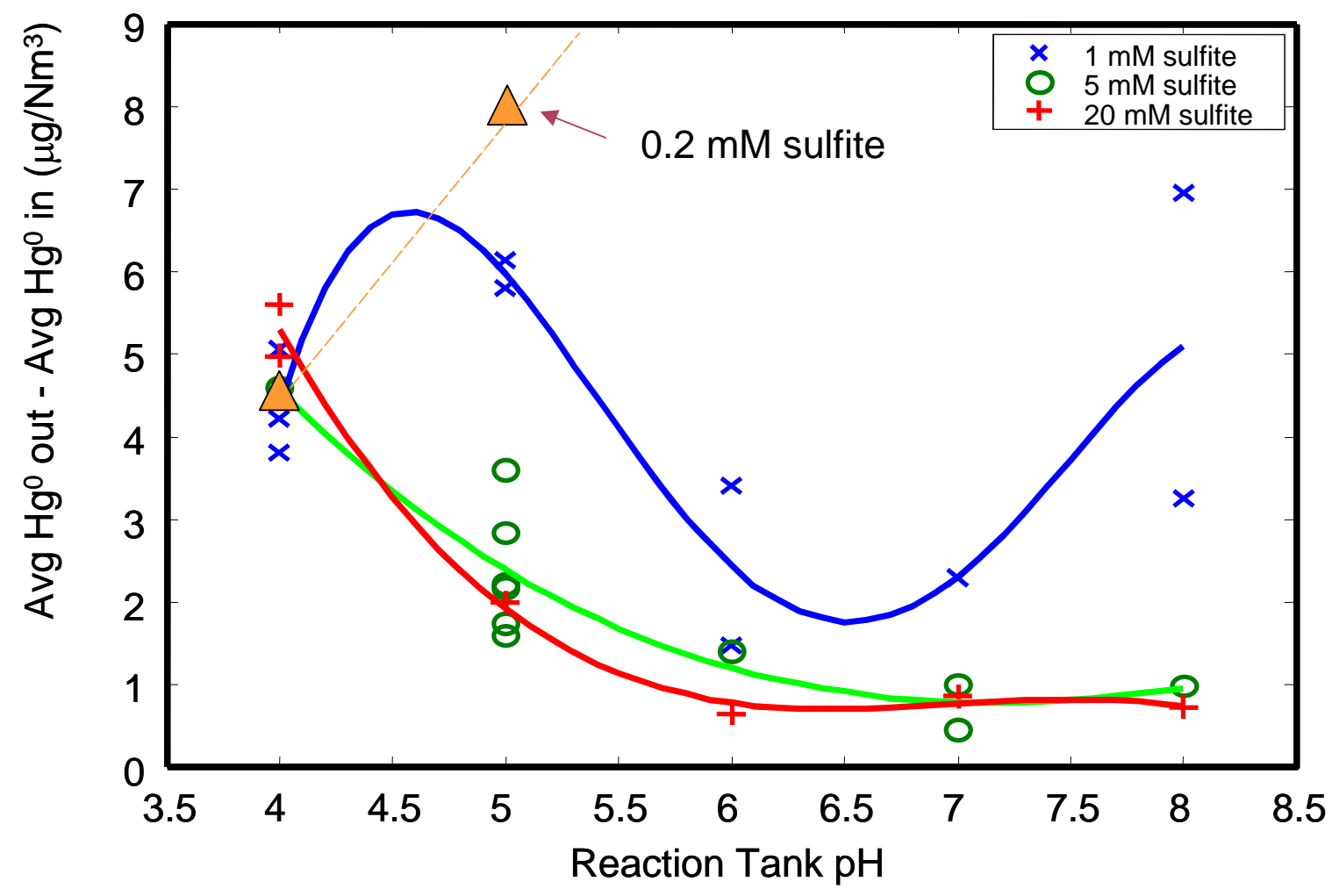

Figure 40. Bench-scale Re-emissions as a Function of $\mathrm{pH}$, including $0.2 \mathrm{mM}$ Sulfite Data 
As shown Table 1 and plotted in Figure 41, increasing the chloride concentration to $250 \mathrm{mM}$ significantly reduces re-emission. Lowering the chloride to $10 \mathrm{mM}$ produces somewhat higher re-emission. Replacing chloride with $100 \mathrm{mM}$ bromide (Run 20) yields somewhat lower reemission than $250 \mathrm{mM}$ chloride.

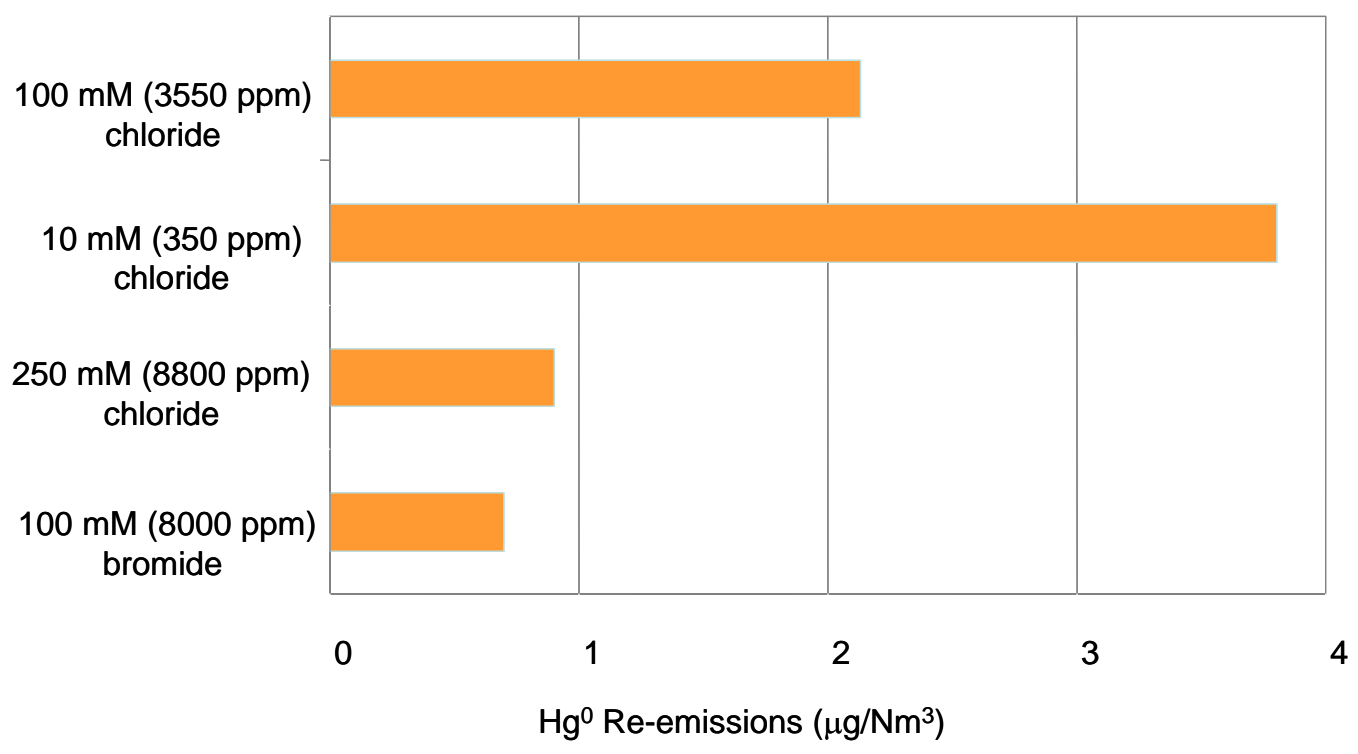

Figure 41. Effects of Chloride and Bromide Concentrations on Bench-scale Mercury Reemissions at pH 5, $5 \mathrm{mM}$ sulfite

\section{Effect of Mercury Concentration in FGD Liquor}

The effect of initial total oxidized mercury in solution (from the injection of the aqueous $\mathrm{HgCl}_{2}$ solution) is shown in Figure 42. The values shown are for the "base case" (see below) of $\mathrm{pH} 5.0$, $5.0 \mathrm{mM}$ sulfite, $100 \mathrm{mM}$ chloride, and $55^{\circ} \mathrm{C}$. The linear relationship agrees with model predictions. The "y-intercept" is approximately the same concentration of elemental mercury as the input to the absorber from the gas mixing apparatus.

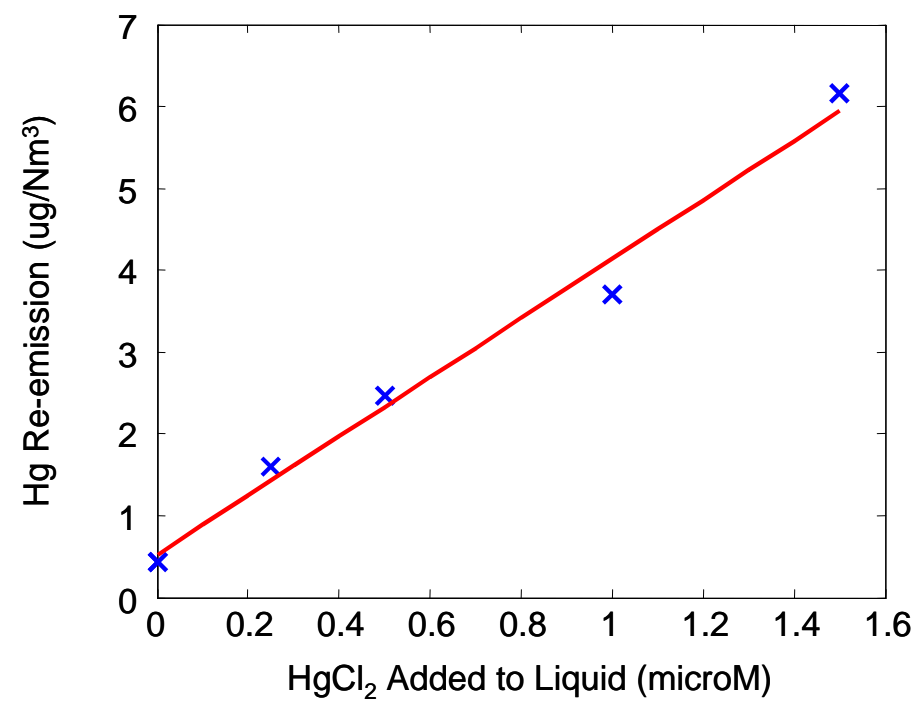

Figure 42. Bench-scale Re-emissions as a Function of $\mathrm{HgCl}_{2}$ Added 


\section{Effect of Other FGD Cations}

The effect of magnesium ion is also complex, and in accord with modeling results it appears that at high sulfite concentrations, magnesium has little effect on re-emission (lowering it somewhat in Run 12). However, at low sulfite concentration $\mathrm{Mg}^{+2}$ tends to increase re-emission (Run 15). This is probably due to the ion pairing of $\mathrm{Mg}^{+2}$ with $\mathrm{SO}_{3}{ }^{-2}$, which tends to lower the effective sulfite concentration, allowing the reduction of mercuric sulfite (and possibly chlorosulfite) complexes to speed up.

Calcium ion, at $15 \mathrm{mM}$, produced a significant increase in re-emissions at the base-case level of $5.0 \mathrm{mM}$ sulfite and $\mathrm{pH} 5.0\left(4.39 \mu \mathrm{g} / \mathrm{Nm}^{3}\right)$. The activity product of $\mathrm{CaCO}_{3}$ is quite low at this $\mathrm{pH}$ and, correspondingly, there was no apparent precipitation of calcium salts during this run. One might expect an ion pairing effect for $\mathrm{CaSO}_{3}{ }^{0}$ similar to that described above for magnesium, and the ion pair association constant for $\mathrm{CaSO}_{3}{ }^{0}$ is approximately three times higher than that of $\mathrm{MgSO}_{3}{ }^{0}$ at $25^{\circ} \mathrm{C} .{ }^{5}$ However, the magnesium effect was only pronounced at low sulfite $(1 \mathrm{mM})$ and $200 \mathrm{mM} \mathrm{Mg}^{+2}$ added. The calcium effect was large with a lower $15 \mathrm{mM} \mathrm{Ca}^{+2}$ concentration added and at a higher, $5 \mathrm{mM}$ sulfite concentration where re-emissions would normally be less. When we varied the calcium concentration, we found that the effect got much smaller or disappeared at $10 \mathrm{mM}$ and $5 \mathrm{mM}$ calcium. This is suggestive of the involvement of a threshold phenomenon such as a phase change. Aqueous equilibrium calculations indicate that although we start with a solution that is subsaturated in $\mathrm{CaSO}_{4} 2 \mathrm{H}_{2} \mathrm{O}$ (gypsum), by the time the $\mathrm{HgCl}_{2}$ is injected to initiate the main part of the run, the sulfate concentration can increase due to sulfite oxidation to a point that is close to or somewhat above the solubility limit of gypsum with 15 $\mathrm{mM} \mathrm{Ca}^{+2}$ present. The lower $10 \mathrm{mM}$ and $5 \mathrm{mM}$ concentrations of calcium used in later runs would be expected to produce solutions that remain subsaturated in gypsum throughout the run. Thus, the increased re-emissions during the $15 \mathrm{mM}$ calcium run seem to be associated with the onset of gypsum nucleation. There may be an effect of gypsum nuclei on the re-emissions reaction, with the active surface perhaps serving as a catalyst. Testing aimed at characterizing such an effect is planned.

In a similar run with $15 \mathrm{mM}$ calcium at $\mathrm{pH}$ 7.0, precipitation and a "cloudy" solution was observed, as expected for precipitation of $\mathrm{CaCO}_{3}$ at this $\mathrm{pH}$. Re-emissions were also relatively high for this run at this $\mathrm{pH}$, measuring $2.50 \mu \mathrm{g} / \mathrm{Nm}^{3}$. Since calcium has a decided effect and it is a component of practically all FGD systems, it was included in the base case formulation for some of the subsequent base case testing.

Since the addition of calcium ion to the solution has a larger and more complex effect than anticipated, we did a series of runs with the calcium level set at $15 \mathrm{mM}$ (close to typical FGD operation) and varied the $\mathrm{pH}$ and sulfite concentration. As shown in Figure 43, the re-emissions rate increased somewhat with calcium ion addition at a reaction tank $\mathrm{pH}$ of 4.0. The effect was much larger at pH 6.0, as shown by Figure 44. Results at pH 5.0 (not plotted) were intermediate between those at $\mathrm{pH} 4.0$ and 6.0 . 


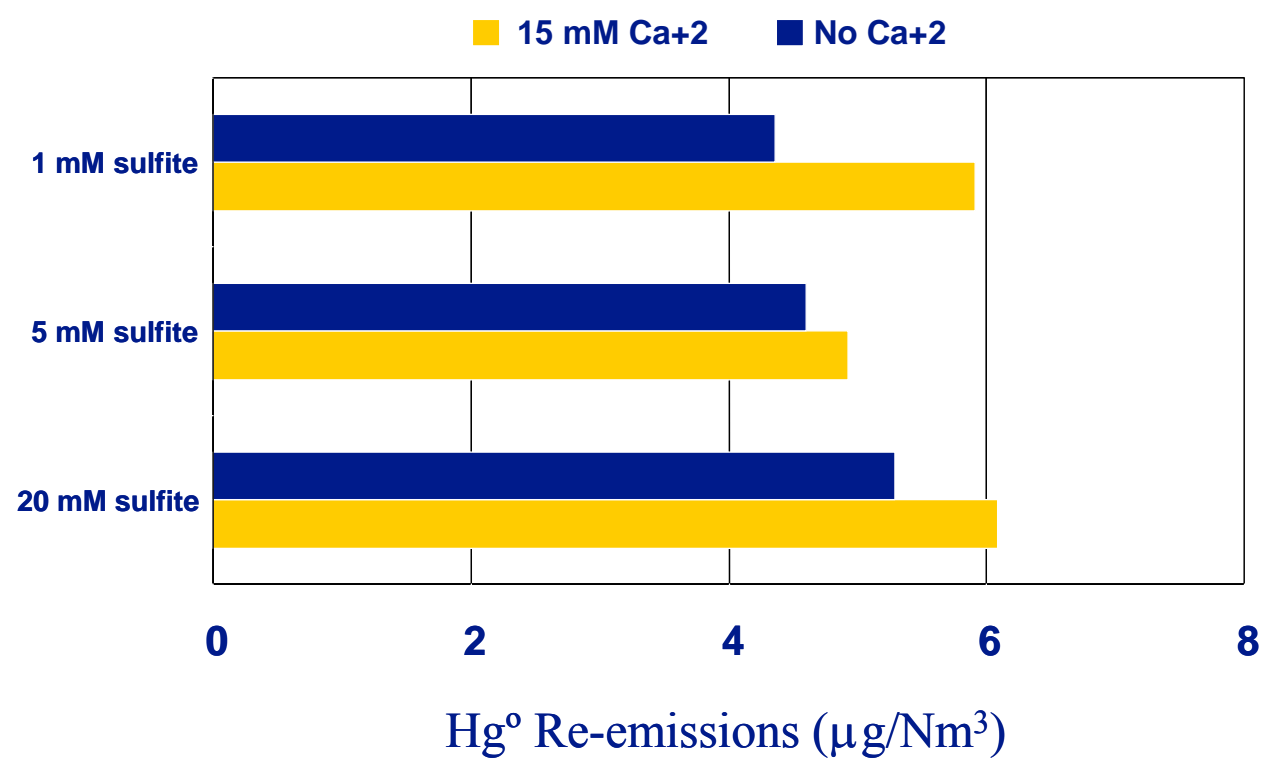

Figure 43. Effect of Calcium on $\mathrm{Hg}^{0}$ Re-emissions at pH 4.0 with Varying Sulfite, $100 \mathrm{mM}$ Chloride

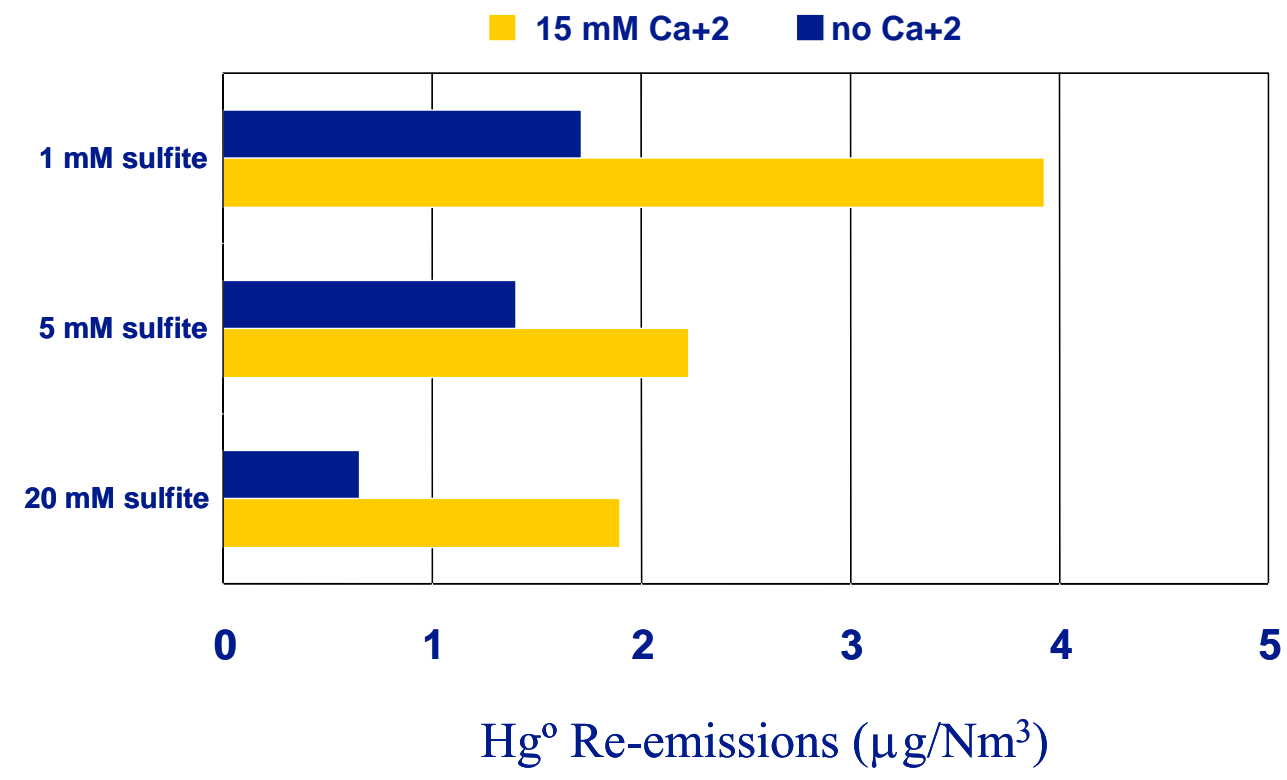

Figure 44. Effect of Calcium on $\mathrm{Hg}^{0}$ Re-emissions at pH 6.0 with Varying Sulfite, $100 \mathrm{mM}$ Chloride

The reason for this behavior is still unclear. It may be that catalysis of the mercuric reduction reactions by calcium ion or calcium sulfate solids are simply more noticeable at higher $\mathrm{pH}$, where the reaction is slower, than at the lowest $\mathrm{pH}$ where the reactions are already rapid. 


\section{Effect of $\mathrm{NO}_{X}$}

The role of $\mathrm{NO}_{\mathrm{X}}$ in the gas stream and resulting nitrogen compounds in the FGD liquor is of interest, especially since these species add another oxidation/reduction component. $\mathrm{NO}_{\mathrm{X}}$ concentrations in the flue gas and nitrogen compound concentrations in the FGD liquor can vary markedly depending on whether the boiler has an SCR in service upstream of the FGD system. Results are shown in Figure 45.

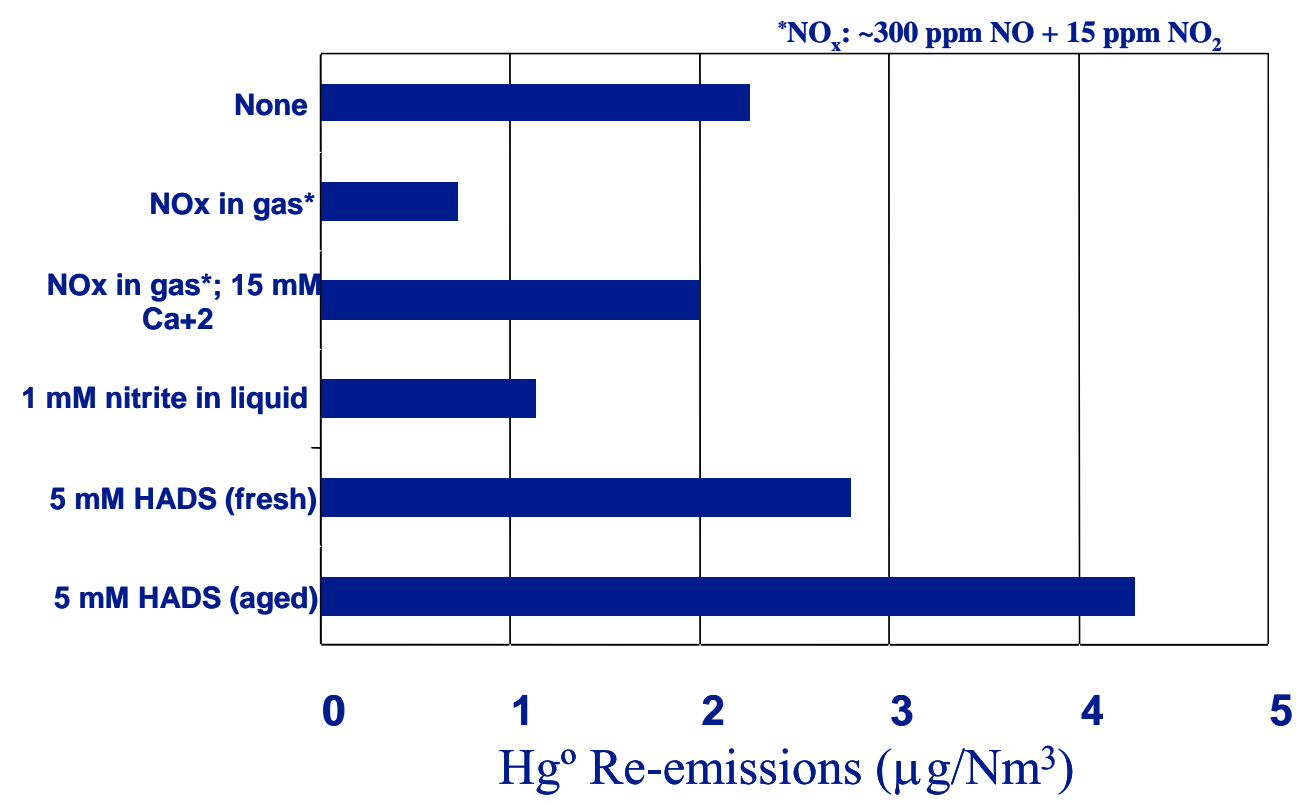

Figure 45. Effect of N-compounds on Bench-scale Re-emissions at $100 \mathrm{mM} \mathrm{Cl}^{-}, 55{ }^{\circ} \mathrm{C}$

Addition of $\mathrm{NO}_{\mathrm{X}}$ to the gas stream produces lower than normal re-emissions. A similar inhibition by $\mathrm{NO}_{\mathrm{X}}$ in the gas was observed in the presence of $15 \mathrm{mM} \mathrm{Ca}^{+2}$. Addition of nitrite, the aqueous anion formed from absorption of $\mathrm{NO}_{\mathrm{X}}$ species in a wet scrubber, in the initial sorbent solution also appeared to inhibit re-emissions to some extent.

However, $\mathrm{NO}_{\mathrm{X}}$ in the FGD inlet flue gas can lead to the formation of sulfur-nitrogen compounds over time, due to a series of reactions that begin with reaction between nitrite and sulfite. Some sulfur-nitrogen species are known to be reducing species and may influence mercury reemissions. During the course of a bench-scale wet FGD run (several hours duration) there is not likely enough time for formation of sulfur-nitrogen species. The formation of sulfur-nitrogen species was simulated in one run with the addition of freshly prepared hydroxylamine disulfonate (HADS), a sulfur-nitrogen compound known to form in some FGD systems, and slightly increased re-emissions. HADS was prepared fresh by reaction of sulfite and nitrite and analyzed by ion chromatography. A larger increase was observed for HADS which was several days old and perhaps contained some "HATS" (hydroxylamine trisulfonate) which can form from further reaction of HADS. In the future, additional work should be conducted on this more complex mixture, as well as runs with $\mathrm{NO}_{\mathrm{x}}$ in the flue gas and HADS added to the FGD liquor at the same time. 


\section{Effect of Inhibited Oxidation FGD Operation}

Thiosulfate, used as a sulfite oxidation inhibitor in some FGD plants, is of interest since it can act as both a strong complexing agent of mercuric ion and a reducing agent. Results obtained with and without addition of $1 \mathrm{mM}$ thiosulfate are shown in Figure 46. As can be seen, thiosulfate is a strong re-emission inhibitor at low $\mathrm{pH}$, probably due to its ability to complex mercuric ion in a $\mathrm{pH}$ region where the sulfite concentration is getting quite low. However, at $\mathrm{pH}$ values above 6, thiosulfate begins to promote re-emissions, either due to interference with the formation of mercuric sulfite complexes or due to activation of thiosulfate's reducing ability.

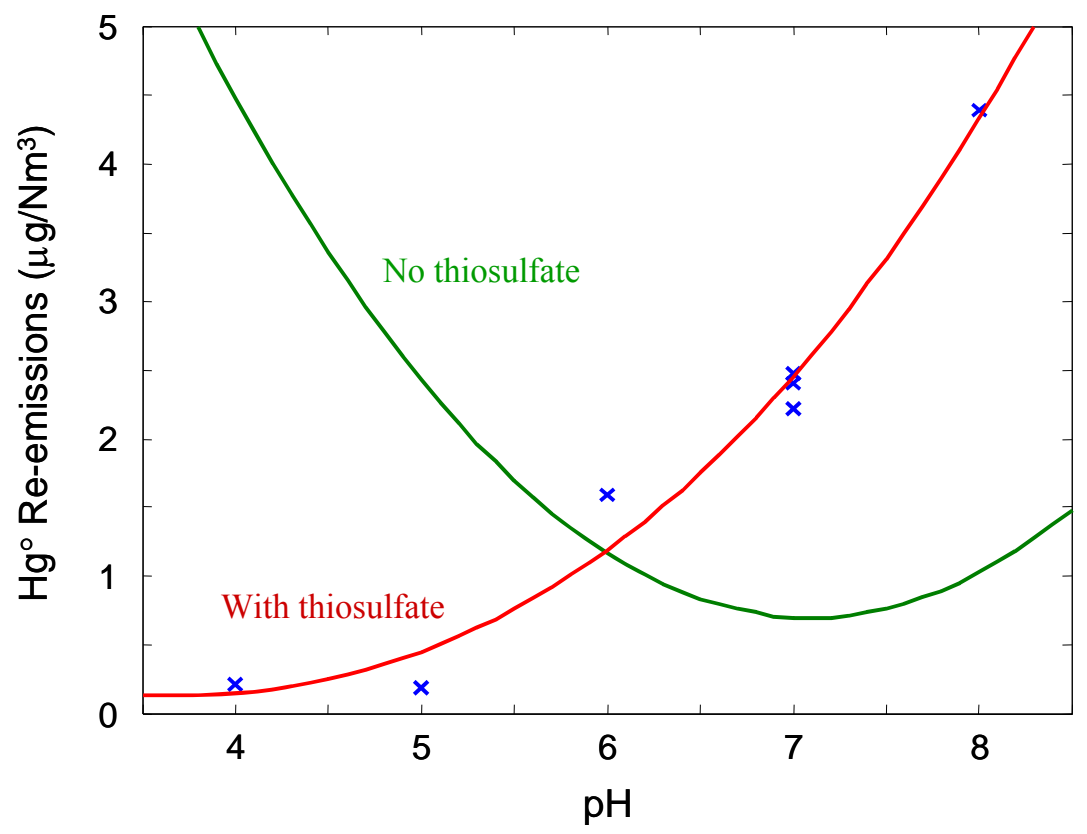

Figure 46. Bench-scale Re-emissions at $1 \mathrm{mM}$ Thiosulfate, as a Function of $\mathrm{pH}$

\section{Effectiveness of Re-emission Inhibitor Additives}

Screening tests were conducted on a number of potential re-emission inhibitors and definite effects have been observed, although with a number of complications.

Somewhat unexpectedly, we have found that carboxylic acids (sometimes used as performance additives in wet limestone FGD systems) tend to promote mercury re-emissions, dramatically in some cases, at the conditions tested. Results obtained at pH 5.0,5 mM sulfite, $100 \mathrm{mM}$ chloride and $55^{\circ} \mathrm{C}$ are shown in Figure 47.

EDTA (ethylenediaminetetraacetate), is a strong chelating agent for mercuric ion and was expected to decrease re-emissions. However, it caused an increase in re-emission when added at the $1 \mathrm{mM}$ level. EDTA had no apparent effect on the measured oxidation-reduction potential (ORP) of the FGD liquor. The increased re-emission may be due to the presence of multiple carboxylic acid groups in EDTA. 


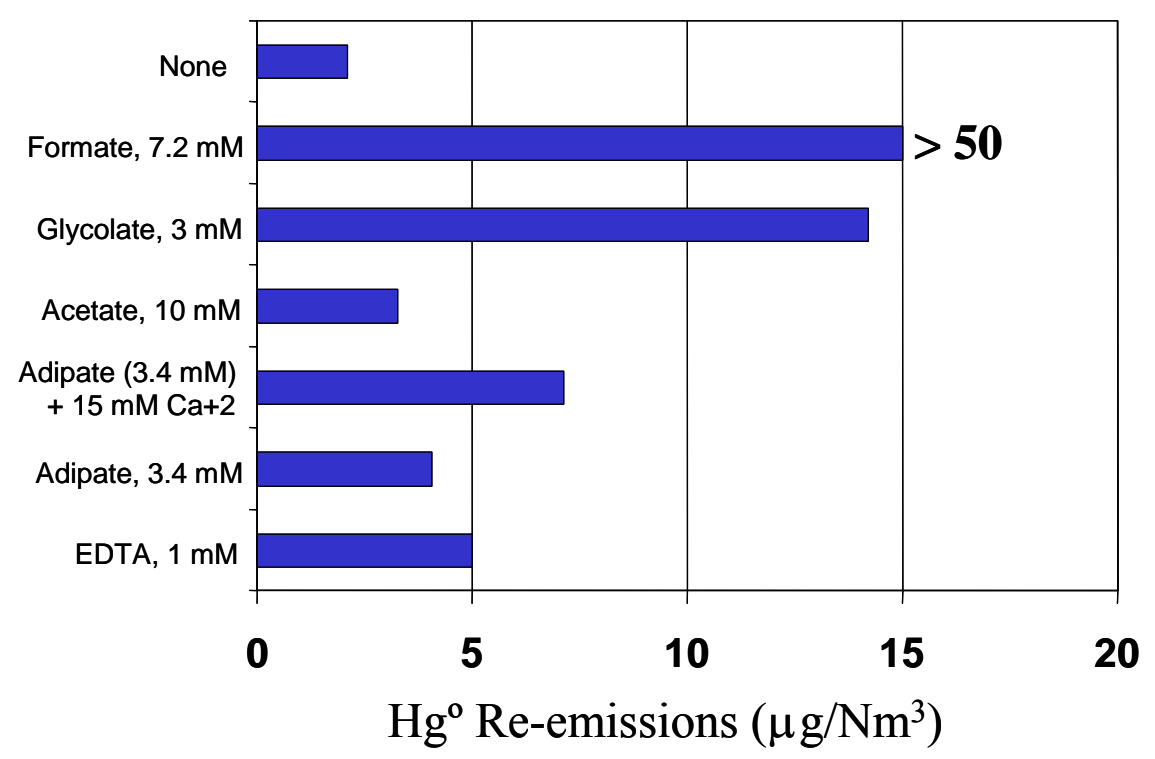

Figure 47. Bench-scale Re-emissions for Carboxylic Acid Salts at $100 \mathrm{mM} \mathrm{Cl}, 55^{\circ} \mathrm{C}$

Adipic acid, a common dibasic acid (having two carboxylic acid groups) and used as a performance additive in some FGD systems also increased re-emissions significantly, although not as much as EDTA. Acetic acid (one carboxylate group) increased re-emissions somewhat but not as much as the compounds with multiple groups. On the other hand, formic acid ( $\mathrm{HCOOH})$ produced extremely high re-emissions. In this case, however, it is probable that the mechanism is different, as formate is known to be a good reducing agent and thus may directly increase the rate of reduction of mercuric species to elemental mercury.

Glycolic acid (which has both single alcohol and carboxyl functional groups, $\mathrm{HOCH}_{2} \mathrm{COOH}$ ) was tested because we suspected that it had been formed in aged spectrophotometric test solutions and caused acceleration of mercury reduction kinetics. The bench scale test (run 68) did indeed show very high mercury re-emissions. All of these carboxylates may be increasing reemissions by interfering with the formation of the disulfite- and chlorosulfite- mercuric complexes that normally inhibit formation of the reactive $\mathrm{HgSO}_{3}$ species. The $\mathrm{HgSO}_{3}$ species undergoes a fast internal redox reaction to elemental mercury, and thus conditions that favor its formation also favor high re-emissions.

Addition of $0.15 \mathrm{mM}$ TMT (trimercapto-s-triazine), which has been suggested as a mercury precipitating agent and re-emissions inhibitor, produced very low (about $0.3 \mu \mathrm{g} / \mathrm{Nm}^{3}$ ) reemissions over much of Run 18. However, there was an initial peak re-emission level of over 5 $\mu \mathrm{g} / \mathrm{Nm}^{3}$ and an apparent increase starting about 3 hours into the run, which produced a short peak re-emission level of about $3 \mu \mathrm{g} / \mathrm{Nm}^{3}$. At this TMT concentration, it appears to shift the ORP to more negative values $(\sim 0$ to $-30 \mathrm{mV})$ than we usually measure $(\sim 50 \mathrm{mV})$.

When using a lower concentration of TMT $(0.01 \mathrm{mM})$, more like that which would be expected for a re-emission control application, a very large initial re-emission peak of about $32 \mu \mathrm{g} / \mathrm{Nm}^{3}$ was observed, followed by a slow decay over several hours to nearly $0 \mu \mathrm{g} / \mathrm{Nm}^{3}$. TMT appears to have some propensity for acting as a reducing agent. The high initial value may be due to 
reduction of the $\mathrm{Hg}^{+2}$ by TMT, and the low final value to precipitation of the TMT-mercury compound.

The time dependence of the emissions in the presence of TMT may be associated with the precipitation kinetics for formation of TMT-Hg solids, which could in turn control the amount of $\mathrm{Hg}^{+2}$ that remains in solution. As we have seen, the mercury re-emissions rate is proportional to the concentration of dissolved $\mathrm{Hg}^{+2}$. This time dependence may be exacerbated by our experimental protocol in which the mercuric compound is added to the reaction tank all at once. If TMT acts primarily by precipitation, there may be a delay in its action due to precipitation kinetics.

Results of several TMT-15 tests at an intermediate concentration of $0.05 \mathrm{mM}$ are summarized in Figure 48. This intermediate value gave erratic results from high re-emissions to somewhat lower than baseline emissions some time after the addition of $\mathrm{Hg}\left(\mathrm{ClO}_{4}\right)_{2}$. After an initial high spike in re-emissions, TMT at $0.05 \mathrm{mM}$ gave low emissions in the presence of $15 \mathrm{mM}$ calcium (Run 69), but was less effective in the presence of $200 \mathrm{mM} \mathrm{Mg}^{+2}$ (run 34). The re-emission observed for $0.05 \mathrm{mM}$ TMT plus $15 \mathrm{mM} \mathrm{Ca}^{+2}$ seems to be anomalously low compared to the other $0.05 \mathrm{mM}$ TMT results. During this run the re-emissions initially spiked to about $13 \mu \mathrm{g} / \mathrm{Nm}^{3}$ when the mercuric salt was injected, but declined to near zero after 1.5 hours. Again, this behavior is suggestive of precipitation kinetics control. A potential explanation is that calcium-based solid nuclei may be aiding the precipitation or adsorption of the mercuric-TMT under these particular conditions. More work is needed to define these complex phenomena.

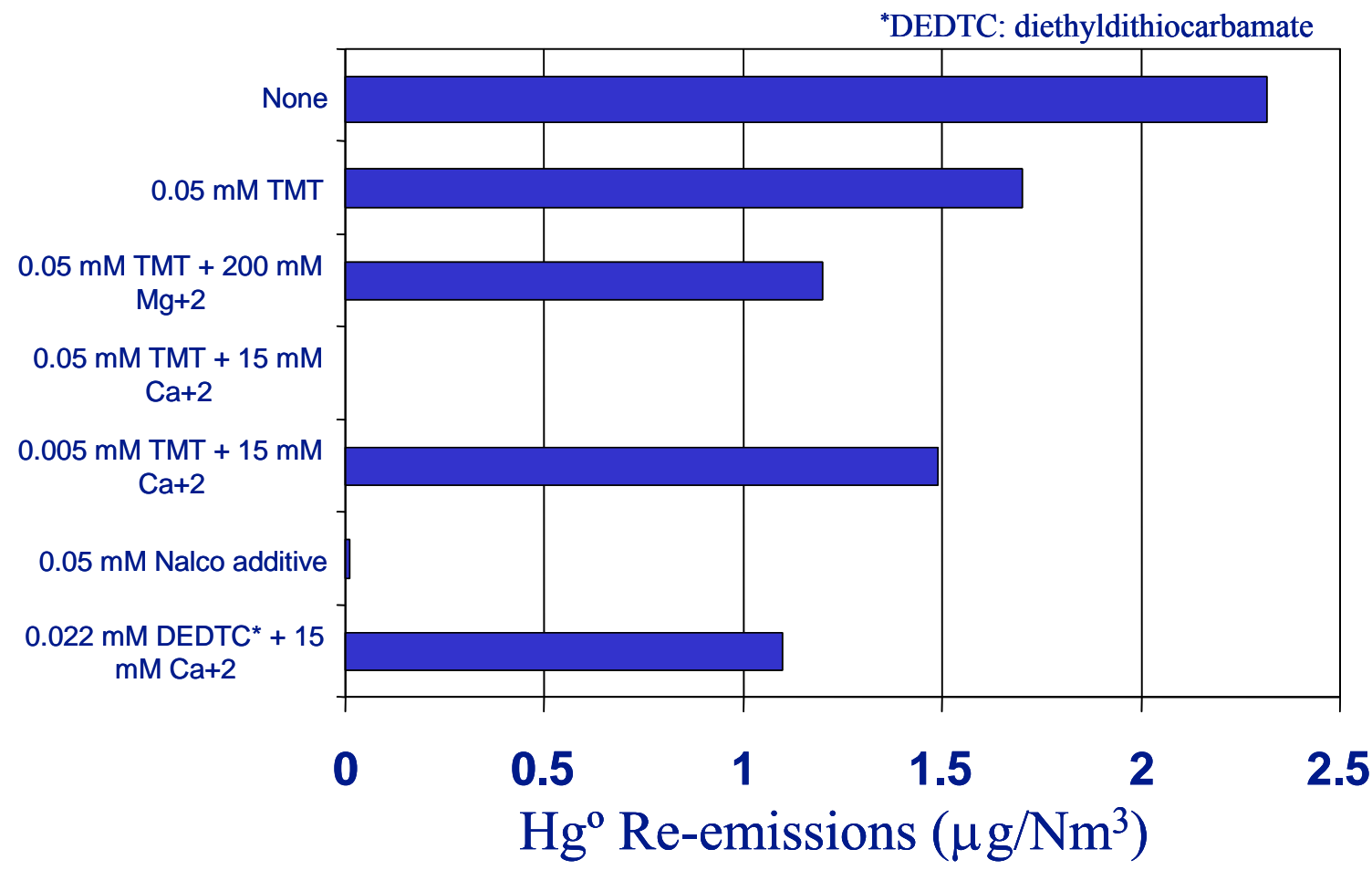

Figure 48. Bench-scale Re-emissions for Several Re-emissions Inhibitors at $100 \mathrm{mM} \mathrm{Cl}^{-}$, $55^{\circ} \mathrm{C}$. 
A few tests were conducted with another potential inhibitor, sodium diethyldithiocarbamate (DEDTC), which appreciably lowers the re-emission rate to about $0.68 \mu \mathrm{g} / \mathrm{Nm}^{3}$ at the $0.15 \mathrm{mM}$ level without any "side effects." Higher, but still below base case emissions of $1.1 \mu \mathrm{g} / \mathrm{Nm}^{3}$ were seen with $0.022 \mathrm{mM}$ DEDTC in the presence of $15 \mathrm{mM} \mathrm{Ca}^{+2}$ (run 85), as shown in Figure 48.

The Nalco Company's 8034 additive appears to be quite effective at limiting re-emissions, although only limited bench-scale testing was completed. The result from one such test is plotted in Figure 48, and shows a re-emission level of nearly zero.

Tests were conducted to screen the effectiveness of a proprietary re-emissions additive from Vosteen Consulting (licensor of the KNX technology to Alstom in the U.S.). The additive, "Pravo," was supplied in a base formulation (Pravo 0) and three alternate formulations (Pravo 1.1, 1.2, and 1.3). Figure 49 shows the results of the screening tests conducted with the Pravo additives compared to average baseline (no additive) results and results from the test with the Nalco additive. Nalco additive number 8034 appears to be a promising re-emissions additive, with near zero re-emissions when added at $0.05 \mathrm{mM}$ (based on the concentration of its proprietary active ingredient).

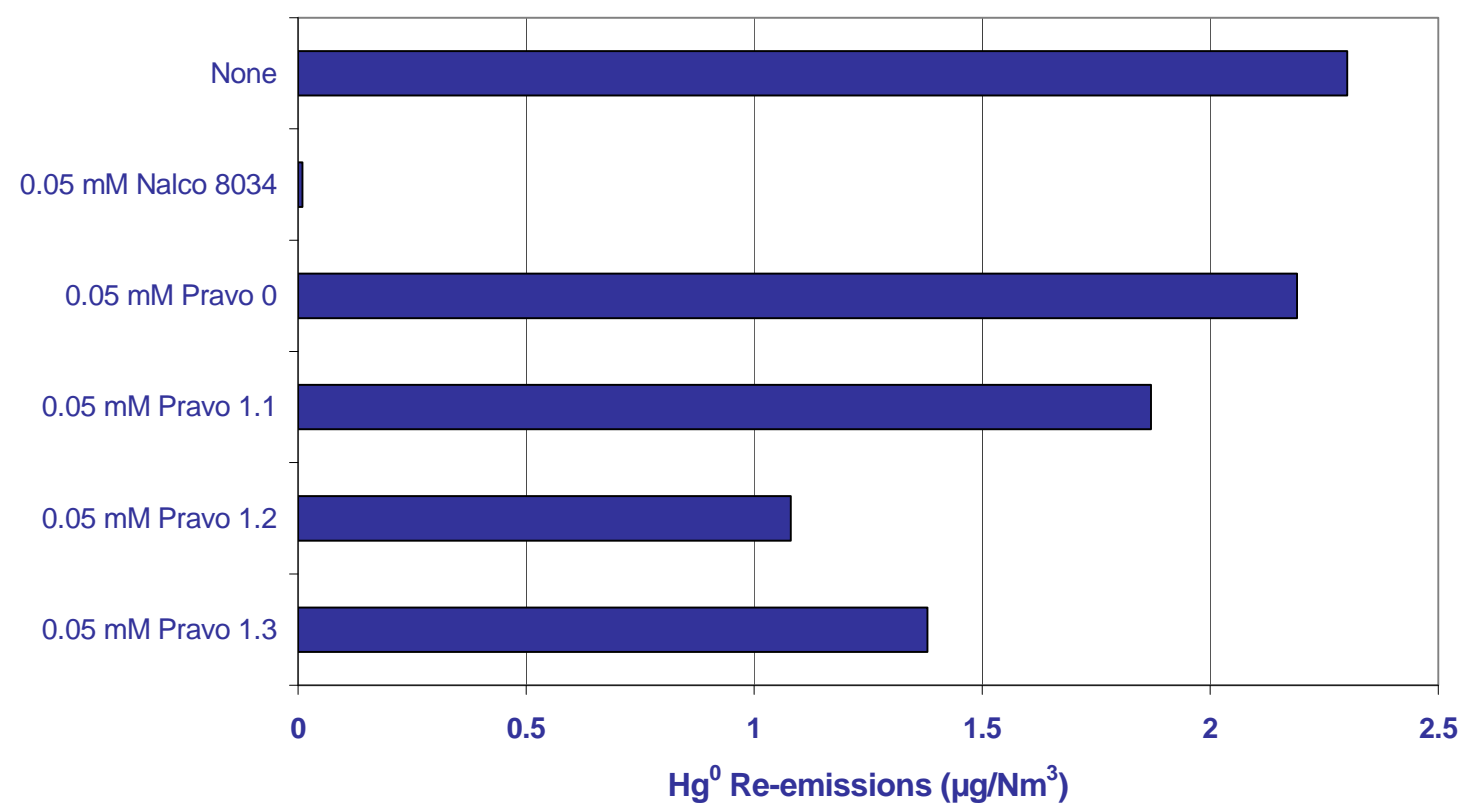

Figure 49. Bench-scale Re-emissions for Additional Re-emissions Inhibitors at pH 5, 100 $\mathrm{mM} \mathrm{Cl}, 55^{\circ} \mathrm{C}$

Of the Pravo formulations tested, the base formulation showed little impact on re-emissions at these conditions, and Pravo 1.1 showed only a small reduction in re-emission levels. Pravo 1.2 was the most effective, cutting emissions by more than $50 \%$ compared to baseline (no additive) operation, while Pravo 1.3 was slightly less effective. Pravo is reportedly used to control reemissions from sodium-based wet scrubbers on European waste incinerators, but has not been tested on a limestone-based FGD system on a coal-fired plant. 
Note that as plotted in Figure 49, Pravo 1.2 does not appear to be as effective as the Nalco 8034 additive in preventing re-emissions, although both additives are reported to have been tested at a dosage of $0.05 \mathrm{mM}$. However, there is a difference in how the millimolar concentrations were calculated for the two additives. Both additives are proprietary and the project team had only limited information available on which to base dosage calculations. In the case of Nalco 8034, the weight percent dissolved solids and the approximate molecular weight of the active ingredient molecule were known, so the millimolar dosage was based on this information. In the case of the Pravo additive, the weight percent solids of the active functional group on the molecule that reacts with mercury was known, so the millimolar dosage was based on this value. Since the Pravo dosage was based on the millimolar quantity of the active functional group while the Nalco 8034 dosage was based on the total molecule (which has numerous active functional groups), the dosage of the Nalco additive was actually higher than the Pravo dosage. More information would have to be known about the Nalco additive to allow calculation of a dosage rate that would be equivalent to the Pravo dosage tested.

\section{Effects of Additional Parameters}

Addition of fly ash (Run 29) produced little or no change in re-emissions. Thus, catalysis of the $\mathrm{Hg}$ re-emission reaction by this fly ash sample was not observed.

Several physical variables have been studied. Lowering the temperature of the scrubber liquor to $50{ }^{\circ} \mathrm{C}$ decreased the re-emissions substantially, as expected from laboratory results, and a run at $45^{\circ} \mathrm{C}$ produced little or no $\mathrm{Hg}$ emissions under base case concentration conditions. Scrubber liquor temperatures are normally measured in the reaction tank, which is located under the absorber, but measurements in the absorber showed essentially the same or slightly lower values than in the reaction tank.

The absorber liquid height (top of the bubbles) was varied from its base case value of 6.0 inches down to 3.0 inches, and up to 9.5 inches in runs 59 and 60 . If having more liquid volume in the absorber increased the kinetics of mercury re-emission, the higher liquid height run should have produced more emissions. Instead, the opposite was found. This indicates that the overall liquor volume in the reaction tank plus absorber is the kinetically pertinent factor, rather than the volume in the absorber alone. This further suggests that the reactions that lead to re-emissions occur while the absorber slurry is being held in the reaction tank and not just while the droplets are in direct flue gas contact in the absorber. The accompanying change in gas/liquid interfacial area with variation of the level in the "bubbler" type absorber is a complicating factor in these tests, but does not appear to account for the observed effect. The absorber $\mathrm{pH}$ values were similar, within 0.1 to $0.2 \mathrm{pH}$ units, for the two cases.

One difference between the runs was that at the lower absorber height the $\mathrm{SO}_{2}$ removal was low $(57 \%)$ as compared to the higher absorber height where it was $89 \%$. Therefore, an explanation for the observed results could be that the effective sulfite concentration in the absorber liquor in the lower absorber height case was lower than in the higher absorber height case. As we have seen, lower sulfite concentration gives higher re-emissions. So, if the "local" sulfite concentration in the absorber (or at the gas-liquid interface) was lower in the low liquor height case, the mercury re-emissions would be higher. Clearly it is necessary to study this further with 
fewer variables at play. One way of doing this could be to vary the inlet $\mathrm{SO}_{2}$ concentration at constant absorber height and liquid flow rate.

There has been speculation that ferric or ferrous iron species may play a role in mercury reemissions since they are redox agents. We did several runs at $\mathrm{pH} 4.0$ with the addition of $10 \mathrm{mM}$ $\mathrm{Fe}\left(\mathrm{ClO}_{4}\right)_{2}(\mathrm{Fe}(\mathrm{II}))$, or $10 \mathrm{mM} \mathrm{Fe}\left(\mathrm{ClO}_{4}\right)_{3}(\mathrm{Fe}(\mathrm{III}))$. The low $\mathrm{pH}$ was used to try to keep as much of the iron (which tends to hydrolyze and precipitate as hydroxides or hydrous oxides) in solution as possible. The ferrous salt initially gave very high re-emissions, peaking at $\sim 60 \mu \mathrm{g} / \mathrm{Nm}^{3}$ but decaying to a steady, much lower value after about one hour. The results obtained for the steady re-emissions regions are shown below in Figure 50.

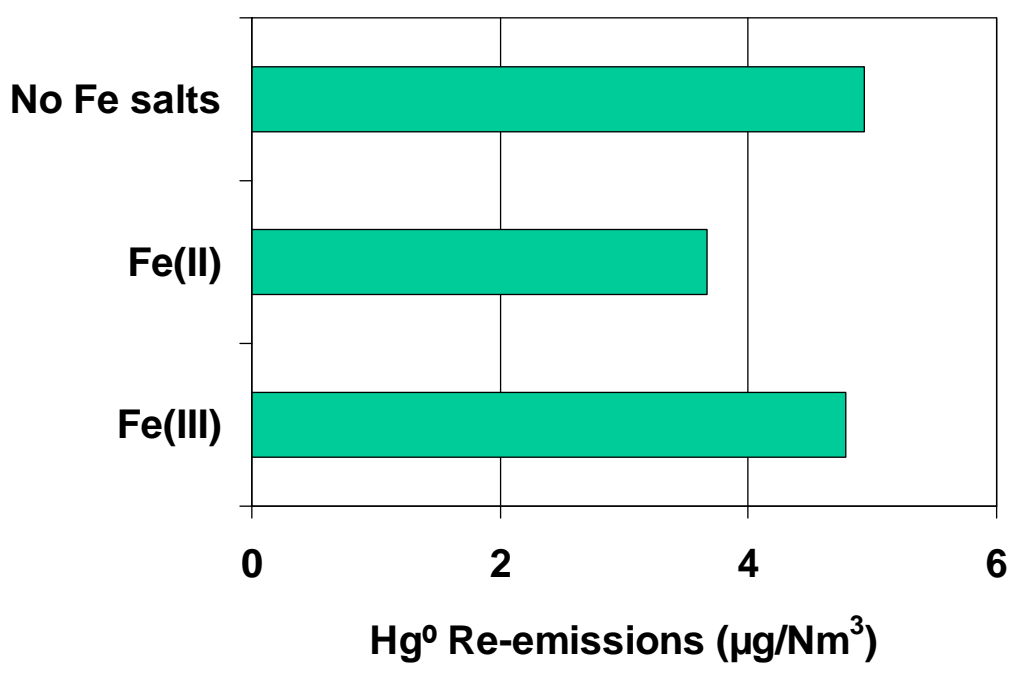

Figure 50. Re-emission Results for $10 \mathrm{mM}$ Iron Salts at pH 4.0, $100 \mathrm{mM}$ Chloride

The initially high results for Fe(II) are probably due to a direct effect of $\mathrm{Fe}(\mathrm{II})$, a reducing agent, resulting in a reaction which reduced mercuric species to elemental mercury. This may have decayed either due to oxidation of Fe(II) in the FGD solution or depletion of the species subject to $\mathrm{Fe}(\mathrm{II})$ attack.

Aqueous Fe(III) does not appear to affect mercury re-emissions under these conditions. However, precipitation of fine iron (III) hydroxide solids in FGD absorbers may lead to coprecipitation and/or adsorption of mercury out of the FGD liquor, and may indirectly affect reemissions due to the effects of dissolved mercury concentration on re-emissions (see Figure 42). This phenomenon should be investigated in the bench-scale wet FGD system in the future.

\section{Kinetics Modeling}

As is the case for most "real world" reacting chemical systems, the reactions under investigation represent composites of several simpler reactions, and are not subject to analytic, single-reaction kinetic equation analysis. Therefore, as the project progressed, the results discussed above were interpreted and incorporated into a chemical kinetics model that can numerically solve relatively large systems of chemical kinetics differential equations (representing approximately 30 to 60 
individual reactions). URS Corporation has developed kinetics modeling software that keeps a database of reactions and rate constants along with a database of reaction conditions such as initial concentrations and temperature. A driver program sends these inputs to a very efficient differential equation solver that produces a set of time-dependent concentrations for all species. Experimental data can be displayed alongside the calculated results.

The solver simultaneously solves the set of ordinary differential equations using a semi-implicit Runge-Kutta method with automatic interval-step-size adjustment. Given a set of reactions, the rate constants for the reactions, and the initial concentrations of reactants, the program produces concentration-time profiles for all chemical species in the reaction set. The model is developed by entering known or measured rate constants, then fine tuned by comparing experimental timeconcentration profiles to the calculated profile and varying unknown or uncertain rate constants until a satisfactory match is obtained over a wide range of conditions of $\mathrm{pH}$, temperature, and ionic strength.

Considerable progress was made on adapting this general model to the present mercury reemissions investigation during the Task 2 kinetics data gathering effort. All of the pertinent reactions found in the $\mathrm{Hg}$-sulfite kinetics literature were added to the model. In addition, reactions that model mercuric ion-chloride equilibria were added, although rate constants for most of these reactions were not available and estimates were used. Many of the temperature dependences of the individual rate constants are also unknown. However, relationships between the forward and back rate constants and the heats of reaction were used to obtain an internally consistent data set that allows the proper temperature dependence of the equilibrium constants to be maintained.

As Task 3 progressed, the model was continually updated, and several candidate reactions were added while other reactions previously considered were eliminated as not being significant. Of a list of candidate reactions totaling upwards of 70, the current model uses 25 reactions. The data set developed at the end of Task 3 , which includes these 25 reactions, is shown in Table 2. In Table $2 \mathrm{~A}$ is the pre-exponential factor (in units of gmole, $\mathrm{L}$, and second) and $\mathrm{E}_{\text {act }}$ is the activation energy ( $\mathrm{kcal} / \mathrm{gmole})$ in the Arrhenius equation, $\mathrm{k}=\mathrm{A} \exp \left(-\mathrm{E}_{\mathrm{ac}} / \mathrm{RT}\right)$, where $\mathrm{R}$ is 1.987 $\mathrm{cal} /\left(\right.$ gmole- $\left.{ }^{\circ} \mathrm{K}\right)$ and $\mathrm{T}$ is the absolute temperature in degrees Kelvin $\left({ }^{\circ} \mathrm{K}\right)$. These parameters are for the forward reaction as shown in the first column.

Table 2. Reaction Set and Kinetics Parameters for $\mathrm{Hg}-\mathrm{SO}_{2}$ Reaction Model as Determined at Completion of the Task 3 Kinetics Data Gathering Effort (see text for symbol explanation and units)

\begin{tabular}{|l|l|l|}
\hline Reaction & A & $E_{\text {act }}$ \\
\hline $\mathrm{H}_{2} \mathrm{O} \rightarrow \mathrm{H}^{+}+\mathrm{OH}^{-}$ & $1.0 \mathrm{E}-04$ & $1.59 \mathrm{E}+01$ \\
\hline $\mathrm{Mg}^{+2}+\mathrm{SO}_{3}^{-2} \rightarrow \mathrm{MgSO}_{3}$ & $8.3 \mathrm{E}+09$ & $3.0 \mathrm{E}+00$ \\
\hline $\mathrm{H}^{+}+\mathrm{SO}_{3}^{-2} \rightarrow \mathrm{HSO}_{3}^{-}$ & $1.0 \mathrm{E}+11$ & $3.0 \mathrm{E}+00$ \\
\hline $\mathrm{H}^{+}+\mathrm{HSO}_{3}^{-} \rightarrow \mathrm{SO}_{2}+\mathrm{H}_{2} \mathrm{O}$ & $1.0 \mathrm{E}+11$ & $3.0 \mathrm{E}+00$ \\
\hline
\end{tabular}




\begin{tabular}{|c|c|c|}
\hline Reaction & A & $E_{\text {act }}$ \\
\hline $\mathrm{Hg}^{+2}+\mathrm{SO}_{3}^{-2} \rightarrow \mathrm{HgSO}_{3}$ & $1.0 \mathrm{E}+08$ & $1.0 \mathrm{E}+01$ \\
\hline $\mathrm{HgSO}_{3}+\mathrm{SO}_{3}^{-2} \rightarrow \mathrm{Hg}\left(\mathrm{SO}_{3}\right)^{-2}$ & $2.18 \mathrm{E}+07$ & $3.00 \mathrm{E}+00$ \\
\hline $\mathrm{HgSO}_{3}+\mathrm{H}_{2} \mathrm{O} \rightarrow \mathrm{Hg}^{0}+\mathrm{HSO}_{4}^{-}+\mathrm{H}^{+}$ & 1.06E-02 & $1.7 \mathrm{E}+01$ \\
\hline $\mathrm{Hg}($ gas $) \rightarrow \mathrm{Hg}^{0}$ & 1.00E-01 & $5.3 \mathrm{E}+00$ \\
\hline $\mathrm{Hg}^{+2}+\mathrm{Cl}^{-} \rightarrow \mathrm{HgCl}^{+}$ & $1.00 \mathrm{E}+05$ & $0.0 E+00$ \\
\hline $\mathrm{HgCl}^{+}+\mathrm{Cl}^{-} \rightarrow \mathrm{HgCl}_{2}$ & 7.00E+09 & $0.0 \mathrm{E}+00$ \\
\hline $\mathrm{HgCl}_{2}+\mathrm{Cl}^{-} \rightarrow \mathrm{HgCl}_{3}^{-}$ & $6.70 \mathrm{E}+00$ & $1.12 \mathrm{E}+01$ \\
\hline $\mathrm{HgCl}_{3}^{-}+\mathrm{Cl}^{-} \rightarrow \mathrm{HgCl}_{4}^{-2}$ & $1.30 \mathrm{E}+09$ & $1.16 \mathrm{E}+01$ \\
\hline $\mathrm{Hg}^{+2}+\mathrm{H}_{2} \mathrm{O} \rightarrow \mathrm{HgOH}^{+}+\mathrm{H}^{+}$ & 2.6E-04 & $1.33 E+01$ \\
\hline $\mathrm{HgOH}^{+}+\mathrm{H}_{2} \mathrm{O} \rightarrow \mathrm{Hg}(\mathrm{OH})_{2}+\mathrm{H}^{+}$ & 2.6E-03 & $1.21 \mathrm{E}+01$ \\
\hline $\mathrm{Hg}^{+2}+\mathrm{S}_{2} \mathrm{O}_{3}^{-2} \rightarrow \mathrm{HgS}_{2} \mathrm{O}_{3}$ & $2.00 \mathrm{E}+07$ & $0.00 E+00$ \\
\hline $\mathrm{HgS}_{2} \mathrm{O}_{3}+\mathrm{S}_{2} \mathrm{O}_{3}^{-2} \rightarrow \mathrm{Hg}\left(\mathrm{S}_{2} \mathrm{O}_{3}\right)_{2}^{-2}$ & $1.00 \mathrm{E}+02$ & $0.00 \mathrm{E}+00$ \\
\hline $\mathrm{HgCl}_{2}+\mathrm{SO}_{3}^{-2} \rightarrow \mathrm{ClHgSO}_{3}^{-}+\mathrm{Cl}^{-}$ & $1.00 \mathrm{E}+08$ & $1.0 \mathrm{E}+01$ \\
\hline $\mathrm{ClHgSO}_{3}^{-}+\mathrm{H}_{2} \mathrm{O} \rightarrow \mathrm{Hg}^{0}+\mathrm{HSO}_{4}^{-}+\mathrm{Cl}^{-}+\mathrm{H}^{+}$ & 2.0E-03 & $0.00 E+00$ \\
\hline $\mathrm{Ca}^{+2}+\mathrm{SO}_{3}^{-2} \rightarrow \mathrm{CaSO}_{3}$ & $2.50 \mathrm{E}+09$ & $3.00 \mathrm{E}+00$ \\
\hline $\mathrm{ClHgSO}_{3}^{-}+\mathrm{Cl}^{-} \rightarrow \mathrm{Cl}_{2} \mathrm{HgSO}_{3}^{-2}$ & $7.00 \mathrm{E}+02$ & $1.00 \mathrm{E}+01$ \\
\hline $\mathrm{ClHgSO}_{3}^{-} \rightarrow \mathrm{HgSO}_{3}+\mathrm{Cl}^{-}$ & $1.5 \mathrm{E}+00$ & $0.00 E+00$ \\
\hline $\mathrm{HgSO}_{3}+\mathrm{OH}^{-} \rightarrow \mathrm{Hg}^{0}+\mathrm{SO}_{4}^{-2}+\mathrm{H}^{+}$ & $1.0 \mathrm{E}+06$ & $1.00 \mathrm{E}+01$ \\
\hline $\mathrm{Hg}^{+2}+\operatorname{Inh} \rightarrow$ Hglnh (generic inhibitor) & $1.0 \mathrm{E}+10$ & $0.00 E+00$ \\
\hline $\mathrm{HgSO}_{3}+\mathrm{e}^{-1} \rightarrow \mathrm{Hg}^{0}+\mathrm{e}^{+1}+\mathrm{SO}_{3}^{-2}$ (electron transfer) & $1.0 \mathrm{E}+02$ & $1.00 \mathrm{E}+01$ \\
\hline $\begin{array}{l}\mathrm{HgSO}_{3}+\mathrm{Acc}+\mathrm{H}_{2} \mathrm{O} \rightarrow \mathrm{Hg}^{0}+2 \mathrm{H}^{+}+\mathrm{Acc}+\mathrm{SO}_{4}^{-2} \text { (generic } \\
\text { accelerant) }\end{array}$ & $5.0 \mathrm{E}+00$ & $1.00 \mathrm{E}+01$ \\
\hline
\end{tabular}

We continually updated the model and examined new ideas about mechanisms, including the effect of adding different mixed chloro-sulfito mercuric complexes. We also did experimental runs that enabled us to include better estimates of the mercuric-chloride rate constants, which are largely unreported in the literature. Work was also done on modeling the $\mathrm{Hg}^{0}$ stripping kinetics apparatus as a continuous flow reactor.

A good numerical fit has been obtained under some, but not all conditions. However, in spite of the need to improve the model fit at some conditions, the model implies that the mechanism of 
reduction proceeds primarily via the chloromercuric sulfite complexes in more acidic solutions. The chloride essentially provides a ceiling to limit the rate of reaction at low $\mathrm{pH}$. The mechanism changes to primarily occur through the mercuric disulfite complex at higher $\mathrm{pH}$. This change of mechanism could explain some of the "complex" behavior often observed in re-emission results. Even at higher $\mathrm{pH}$ the chloromercuric sulfite complexes play a role, because without them the mercuric chloride complexes tend to shut down mercuric reduction completely at approximately the $100 \mathrm{mM}(\sim 3500 \mathrm{ppm})$ chloride level. As was shown previously in Figure 37, the model is predicting the basic trends seen experimentally for $\mathrm{pH}$ and sulfite effects. It is also showing fairly good numerical agreement with these and the chloride-dependence data. A simplified schematic depiction of the model reactions is shown in Figure 51.

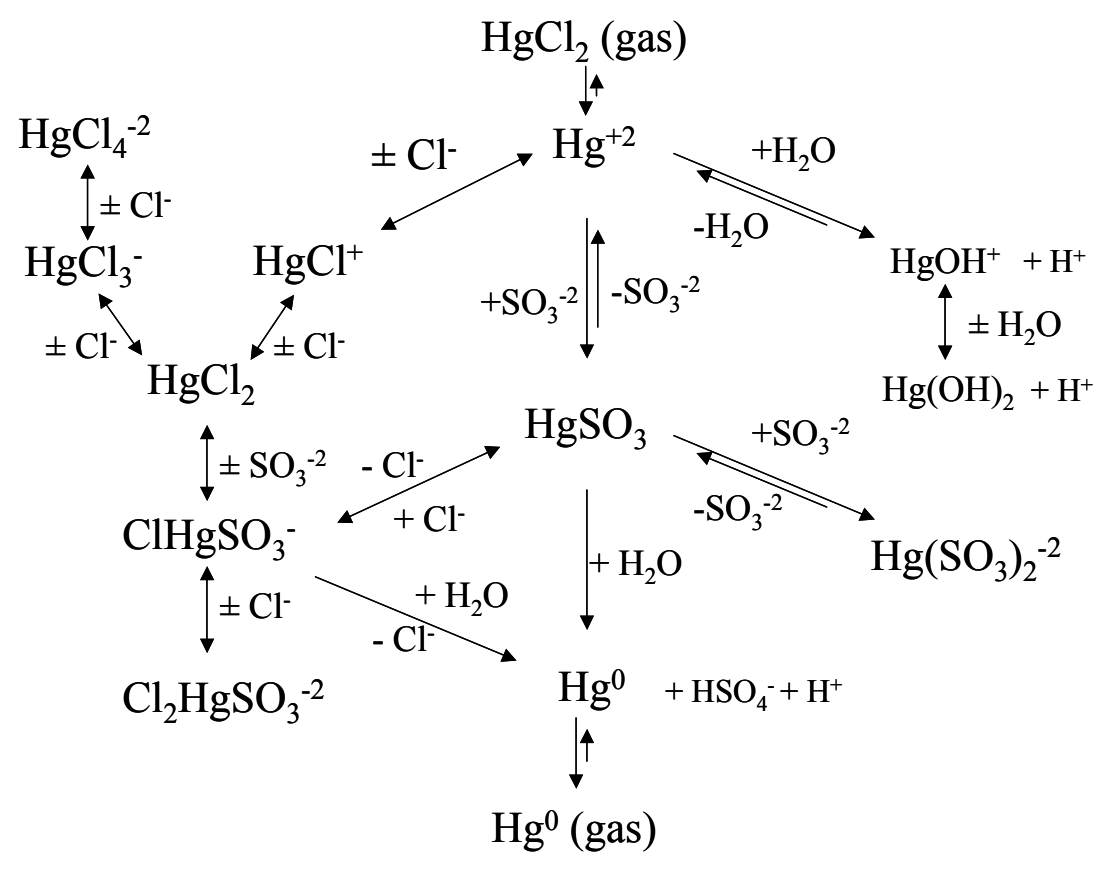

Figure 51. Schematic Diagram of Main Reaction Pathways in Current Kinetics Model

The Task 3 wet FGD bench scale testing provided results over a wider range of conditions than could be followed spectroscopically and produced some unexpected results. As discussed in the previous subsection, one of these is an increase in rate of mercuric reduction at high $\mathrm{pH}$ and low sulfite. A reaction was subsequently added to the kinetics model which seems to account for this, assuming catalysis of the mercuric sulfite $\left(\mathrm{HgSO}_{3}{ }^{0}\right)$ redox reaction under basic conditions.

$\mathrm{HgSO}_{3}{ }^{0}+\mathrm{OH}^{-} \rightarrow \mathrm{Hg}^{0}+\mathrm{SO}_{4}^{-2}+\mathrm{H}^{+}$

This is a reasonable reaction that appears to occur in parallel with the usual reaction (which is often a rate limiting step) involving $\mathrm{H}_{2} \mathrm{O}$ in place of $\mathrm{OH}^{-}$. The new reaction only becomes important relative to the reaction involving $\mathrm{H}_{2} \mathrm{O}$ at elevated $\mathrm{pH}$ (e.g., $\mathrm{pH}>7$ ).

Reactions for formation of $\mathrm{MgSO}_{3}{ }^{0}$ and $\mathrm{CaSO}_{3}{ }^{0}$ ion pairs were also added to the model, to address some of the magnesium and calcium effects discussed in the previous subsection. 
We have not developed a good explanation for the "induction time" behavior seen in some experiments. There are several possible sources of this behavior. One of these is buildup of elemental mercury product, which could react with mercuric complexes or reaction intermediates. Bulk phase elemental mercury is very insoluble in water $\left(0.3 \mu \mathrm{M}\right.$ at $\left.25^{\circ} \mathrm{C}\right)$, but formation of colloidal mercury is well known in the literature. Although we did not observe such formation visibly, colloids are often invisible to the eye.

Also, there was some preliminary spectrophotometric evidence that sulfite was being decomposed at more than stoichiometric amounts in some runs. If this is true, there is the possibility that mercury catalyzes the disproportionation of sulfite, which is thermodynamically favored but very slow under most conditions. Complete disproportionation of sulfite is represented by:

$$
4 \mathrm{SO}_{3}^{-2} \rightarrow 3 \mathrm{SO}_{4}^{-2}+\mathrm{S}^{-2}
$$

Other reduced sulfur compounds may also be formed. These reduced sulfur species could provide a pathway for the fast reduction we see after an induction time in some runs. There is also another interesting application. Anecdotal reports of "mercuric sulfide" being formed in FGD systems is fairly common, although sulfide is not normally present in FGD liquors. However, if sulfide were formed via catalysis by mercury, it would be near the mercury at a molecular level and could then react with a mercury species to form $\mathrm{HgS}$ before being oxidized. $\mathrm{HgS}$ is highly insoluble and thus could be separated from the liquid phase reactions as a solid.

It should be noted that the reactions, rate constants and activation energy values shown in Table 2 should be considered a "work in progress" even though this project is at its completion. The reaction mechanisms involved in mercury re-emissions proved to be more complex than was envisioned at the outset of this project. Although the current form of the model fits much of the experimental data reasonably well, not all conditions are accurately predicted.

Furthermore, over the time period that this project has been conducted, more information has become available from sampling of full-scale wet FGD systems which indicates that there is a mechanism whereby mercury is adsorbed on and/or co-precipitated with solids in the FGD slurry. This mercury phase change will obviously impact re-emission kinetics; if the $\mathrm{Hg}^{+2}$ is no longer in the FGD liquor it is not available to participate in the aqueous phase reactions shown in Table 2. An integrated re-emission model will have to consider this phase change in how it impacts overall re-emission rates. More work is needed to determine the mechanism for this mercury phase change and to develop adsorption and/or co-precipitation rate data as a function of FGD conditions.

\section{Sensors for Dissolved Oxidized Mercury}

According to the results shown earlier in this section, the total oxidized mercury in solution is a key property affecting mercury re-emissions. Data previously collected by EPRI show that this

property varies considerably from site to site, even when comparing FGD systems with similar FGD chemistry (e.g., limestone forced oxidation). In fact, the true total dissolved oxidized mercury may not be accurately known for many plants. Difficulties in sampling, sample preservation, separation of finely divided or colloidal mercury from actual dissolved mercury 
liquids, and the inherent errors in analyzing for low concentrations of mercury in a complex analytical matrix may introduce errors.

Therefore it would be advantageous to have an analytical "sensor" for dissolved oxidized mercury which could be used at a plant on freshly taken samples or in "real time" measurements. While it is not directly within the scope of this project to develop or test an on-line dissolved ionic mercury sensor, a small effort was expended to determine the state of the art of this technology to determine how feasible such monitoring might be. The following summarizes the results of this investigation.

There has been considerable activity in the research literature for the past few years on developing such a sensor for mercury concentrations in aqueous media. These efforts have focused on various methodologies and have been primarily targeted at environmental measurements of mercury concentrations in lakes or other natural waters. Although some of these sensors appear to be approaching the detection limits of interest for mercury in FGD systems, it will take considerable testing and potentially further development to determine their applicability or adapt them to FGD liquors. If such a sensor could be developed, though, it could aid considerably in monitoring and controlling mercury re-emissions.

This report will not attempt to review all of the literature and history of mercury sensors at this point, but instead a few examples of the different methodologies are provided here. Most of the methods have in common the use of a "chemistry" that is very selective for oxidized mercury to obtain the necessary selectivity as well as sensitivity. Incorporation of sulfur into a molecule often increases its selectivity and reactivity with $\mathrm{Hg}^{+2}$, and is often exploited in these methods.

One novel method uses surface plasmon resonance to quantify mercury in solution. Surface plasmons are "collective propagating charge density waves, which are confined to the surface of a solid." ${ }^{6}$ Metals such as silver and gold have particularly good properties for supporting the resonance of surface plasmons with incident p-polarized light. This resonance phenomenon is quite sensitive to species adsorbed on the surface of the metal. Zare and co-workers have applied a surface plasmon resonance technique to analysis of aqueous mercuric ions. ${ }^{7}$ A thin layer of gold supported on a microscope slide is treated with a monolayer of 1,6 hexanedithiol and that side of the assembly is exposed to the aqueous test solution. The active surface was illuminated from the back side with p-polarized laser light and changes in the resonance angle of reflection followed with a split-field photodiode detector also on the back side of the microscopy slide. This sensor responds to oxidized mercury levels concentrations from $1 \mathrm{nM}$ to about $10 \mu \mathrm{M}$ and is relatively insensitive to much higher $100 \mu \mathrm{M}$ concentrations of other divalent metal ions such as $\mathrm{Pb}^{+2}, \mathrm{Ni}^{+2}, \mathrm{Zn}^{+2}$, and $\mathrm{Cu}^{+2}$. However, the reproducibility appears to be only fair at low levels of mercury, and it takes up to 30 minutes to reach a stable measurement value. These characteristics may be subject to optimization.

Electrochemical methods based on chemically modifying electrodes to make them selective for mercury have been under development for a considerable time. One of the most promising of these is one in which "a selective mercury binding agent, such as a chelating agent or clathrating agent, is co-valently bound in a copolymer and deposited as an electrode area." ${ }^{8}$ Standard voltametric measurements can then be used to quantify the mercury in solution as it interacts 
with this electrode. The cathodic peak current is said to be linear with $\mathrm{Hg}^{+2}$ over $\sim 7$ orders of magnitude and display a theoretical detection limit near $\sim 2 \mathrm{ppb}$. Common interferences such as lead or cadmium do not interfere at order-of-magnitude higher concentrations than mercury. Oxygen at water saturation levels also does not interfere. The electrode has to be reconditioned with a nitric acid wash between each determination, though.

A number of studies have been reported recently in which the changes in spectroscopic absorbance or fluorescence of oxidized-mercury-sensitive compounds has been used to detect oxidized mercury concentration. One of these "colorimetric" sensors is based on the ruthenium dye "N719," [bis(2,2'-bipyridyl-4,4'-dicarboxylate)ruthenium(II) bis(tetrabutylammonium) bis(thiocyanate)]. ${ }^{9}$ Mercury ions coordinate reversibly to the sulfur atom of the N-C-S groups on the dye molecule. This interaction causes a color change in the dye at sub-micromolar concentrations of mercury, and this color change is selective for oxidized mercury when compared with other ions such as $\mathrm{Pb}^{+2}, \mathrm{Cd}^{+2}, \mathrm{Zn}^{+2}$, or $\mathrm{Fe}^{+2}$. The detection limit for $\mathrm{Hg}^{+2}$ ions in aqueous solutions using this method is estimated to be $\sim 20 \mathrm{ppb}$.

A gold nanoparticle-based sensor for $\mathrm{Hg}^{+2}$ ions in aqueous solution has been described by Huang and Chang. ${ }^{10}$ This method is based on the weak fluorescence of Rhodamine B adsorbed on gold nanoparticles compared to its strong fluorescence in bulk solution. Mercury added to a solution of Rhodamine-B-adsorbed nanoparticles displaces the Rhodamine from the gold surface, thus causing a large increase in fluorescence due to the unbound dye. Additional selectivity was obtained by modifying the gold nanoparticle surface with thiol ligands and by adding a chelating ligand to the sample solutions. At optimum conditions, the selectivity of the method for $\mathrm{Hg}^{+2}$ is said to be 50 times that of other metal ions and the level of detection in "pond water" is about 2 ppb. 


\section{CONCLUSION}

Experimental methods were developed initially to use spectrophotometry to identify key reaction intermediate species in the reduction of oxidized mercury to elemental mercury and to track their changes in concentration as the reactions proceeded. Separate but complementary methods for following the rate of evolution of mercury in the gas phase, and loss of mercury from the liquid phase were developed and applied. Using these methods, both the rate of disappearance of the mercuric sulfite and chlorosulfite complexes and the rate of formation of elemental mercury product were monitored by independent means. This enabled the project team to map out and model the major reaction pathways, the effects of temperature, reactant concentrations, $\mathrm{pH}$, chloride, thiosulfate, and other complexing agents on the rates of these reactions, and thus on the re-emission of $\mathrm{Hg}$ from FGD systems.

New methods for operating and controlling a bench-scale wet FGD system were developed and a number of these runs were completed. The bench-scale wet FGD runs have confirmed and considerably augmented the initial kinetics results.

Re-emissions increase linearly with total concentration of mercuric salt added to the reaction tank. Even fairly low concentrations of chloride have a significant effect on the rate of mercuric ion reduction by sulfite. Evidence has been found for the formation of complexes of mercuric ion with both sulfite and up to two chloride ions. Each chloride ion attached to the mercury slows the decomposition of the mercuric chloride complex to elemental mercury by a substantial amount. The key role played by the sulfite aqueous species $\left(\mathrm{SO}_{3}{ }^{-2}\right)$ indicates that other solution components (such as magnesium and calcium) which ion pair with sulfite could also influence the kinetics of mercury reduction. Calcium effects on re-emission were found to increase with increasing $\mathrm{pH}$.

Effects of $\mathrm{pH}$ and sulfite concentration are complex and appreciable, particularly at low sulfite concentrations. Low concentrations of sulfite (consistent with forced oxidation conditions) produced high re-emissions and an unusual $\mathrm{pH}$ response: increased re-emissions as the $\mathrm{pH}$ increases from 4.0 to 6.0. At higher sulfite concentrations, re-emissions generally decrease with increasing $\mathrm{pH}$. Thiosulfate appears to inhibit re-emission at low $\mathrm{pH}$, but accelerate it at high $\mathrm{pH}$. Effects of N-compounds are also mixed; sulfur-nitrogen species in the FGD liquor (a result of $\mathrm{NO}_{\mathrm{X}}$ in the scrubbed gas) tend to increase re-emissions while $\mathrm{NO}_{\mathrm{X}}$ in the simulated flue gas (in the absence of sulfur-nitrogen species) tends to lower re-emissions.

Several potential FGD additives have been identified, such as carboxylic acids, which accelerate elemental mercury re-emissions. Several other additives have been identified which decrease elemental mercury re-emissions, in some cases significantly. However, some of these additives may accelerate re-emissions under some conditions, and thus must be applied with caution.

A chemical kinetics model has been developed to describe the aqueous mercury-sulfite-chloridethiosulfate system and takes into account the simultaneous occurrence of a number of reaction steps. The model predicts the basic trends seen experimentally for $\mathrm{pH}$, sulfite, and chloride effects, and gives reasonably good numerical agreement with experimental data. It has been used 
to correlate bench-scale experimental results as well as to predict kinetics in low $\mathrm{pH}$ regions, such as at the $\mathrm{SO}_{2}$ gas-aqueous interface, which are difficult to investigate experimentally.

The results from this project can be used to make several observations as to what FGD conditions would tend to favor or minimize re-emissions:

- Limestone forced oxidation systems - In systems that produce wallboard-grade gypsum, the most advantageous mode of operation (notwithstanding mercury control) is typically at high oxidation air rates to minimize liquor sulfite concentrations in the reaction tank, and with relatively high blow down rates to keep liquor chloride concentrations down. These have the benefits of ensuring 100\% sulfite oxidation in the FGD solids and helping meet gypsum chloride concentration specifications, respectively. However, the results of this project suggest that mercury re-emissions would be minimized by running at higher sulfite and chloride concentrations. Thus, perhaps the sulfite should be controlled no lower than is needed to ensure $100 \%$ oxidation in the byproduct solids, and the chlorides controlled at as high a concentration as the materials of construction allow and at which gypsum chloride limits can be met.

- Low oxidation (sulfite producing) systems - Low oxidation systems should benefit from the resulting elevated sulfite concentrations in the FGD liquor and their effects in lowering re-emission rates. In limestone-based FGD systems that operate at approximately $\mathrm{pH} 6$ or lower, the use of thiosulfate to inhibit sulfite oxidation may have benefits in lowering re-emission rates, particularly in the absorber where the $\mathrm{pH}$ drops. For lime-based systems that operate at a reaction tank $\mathrm{pH}$ above 6.0, thiosulfate addition may have an adverse effect on re-emissions. Re-emissions may be greater at reaction tank conditions with thiosulfate added, but could be reduced in the absorber where the droplet $\mathrm{pH}$ is lower.

- SCR effects - Having an SCR operate upstream of an FGD system could lead to competing impacts on re-emissions. If the SCR markedly increases mercury oxidation upstream of the FGD system, it could lead to higher liquid-phase mercury concentrations in the FGD liquor and corresponding increases in re-emissions. However, the corresponding reduction in $\mathrm{NO}_{\mathrm{X}}$ concentrations in the FGD inlet gas should lead to significantly lower concentrations of sulfur-nitrogen species in the FGD liquor. This should correspondingly lower re-emission rates. Further work would be needed to develop rate data to predict how these effects trade off for a particular circumstance. Field data indicate that at least for some SCR/wet FGD combinations, having the SCR in operation tends to lower re-emissions. ${ }^{11}$

- Re-emissions control additives - The results from this investigation show several commercially available additives with promise for controlling re-emissions. For some additives (e.g., TMT-15) these results suggest that the additive dosage should be the minimum required to limit re-emissions; higher dosages can lead to direct reduction of mercury by the additive before it acts to limit re-emissions by precipitating the mercury. More work is needed to investigate the effectiveness of re-emission additives, particularly in full-scale trials conducted at varying additive dosages. 
However, it should be noted that these findings are based on project results and reflect benchscale FGD operation in a synthetic flue gas and in mostly sodium-based scrubbing solutions. Impurities in an actual flue gas environment such as from fly ash removed by the scrubber and from the dissolution of limestone reagents may impact these findings. Also, as shown in this report operation in a high-calcium environment rather than a high-sodium environment may affect the re-emissions chemistry. EPRI is funding additional work in the coming year to investigate these effects. 


\section{REFERENCES}

1. Carey, T.R., et al. "Effect of Mercury Speciation on Removal Across Wet FGD Processes." Presented at the AIChE Spring National Meeting, Session 47, New Orleans, LA, February 25-29, 1996.

2. Scoggins, M. W., "Ultraviolet Spectrophotometric Determination of Sulfur Dioxide," Analytical Chemistry 42 (9), 1091 (1970).

3. Dasgupta, P. K., and K. B. DeCesare, "Stability of Sulfur Dioxide in Formaldehyde Absorber and its Anomalous Behavior in Tetrachloromercurate(II)," Atmospheric Environment, 16 (12), 2927 (1982).

4. Oda, C. E. and J. D. Ingle, Jr., "Continuous Flow Cold Vapor Atomic Absorption Determination of Mercury," Anal. Chem., 53, 2030 (1981).

5. Lowell, Philip S., Delbert M. Ottmers, Jr., Klaus Schwitzgebel, Thomas I. Strange, and David W. DeBerry, "A Theoretical Description of the Limestone Injection - Wet Scrubbing Process," Final Report for Contract No. CPA-22-69-138 to the National Air Pollution Control Administration, June, 1970. Vol. I, Table IV-2.

6. Gale, Robert James, ed., Spectroelectrochemistry, Theory and Practice, New York: Plenum Press, 1988. p. 143.

7. Chah, Soonwoo, Jongheop Yi, and Richard N. Zare, "Surface plasmon resonance analysis of aqueous mercuric ions," Sensors and Actuators, B, 99, 216, 2004.

8. Russell, Dale D., "Mercury Selective Electrode," US Patent 6,436,259, 2002. Also see Jon Scaggs, Dale D. Russell, S.P. Duttagupta, and Michael W. Hill, Mat. Res. Soc. Symp. Proc. Vol. 665, C5.2.1, 2001.

9. Eugenio Coronado, Jose R. Galan-Mascaros, Carlos Marti-Gastaldo, Emilio Palomares, James R. Durrant, Ramon Vilar, M. Gratzel, and Md. K. Nazeeruddin, "Reversible Colorimetric Probes for Mercury Sensing," J. Am. Chem. Soc. 127, 12351, 2005.

10. Huang, Chih-Ching and Huan-Tsung Chang, "Selective Gold-Nanoparticle-Based "TurnOn" Fluorescent Sensors for Detection of Mercury(II) in Aqueous Solution," Anal. Chem., 78(24), 8332, 2006.

11. Impact of $\mathrm{NO}_{X}$ Controls on Mercury Controllability: Update 2002, EPRI, Palo Alto, CA: 2002. 1004268 . 